
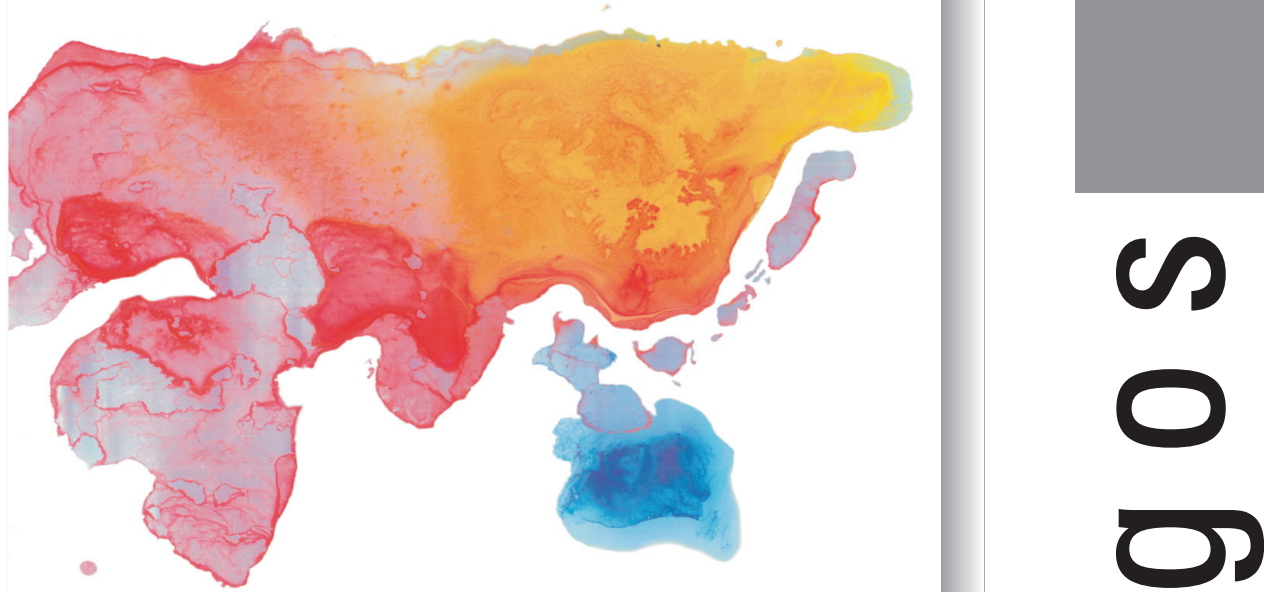

$\square$
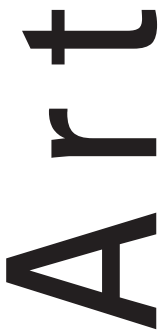


\title{
0 índice de desenvolvimento humano (IDH): avaliação de seus presupostos teóricos e metodológicos.
}

\author{
The index of human development (IDH): avaluation of its theoretical presumptions and \\ metodologycs.
}

Edir de Paiva Bueno - Universidade Federal de Goiás

edirbueno@ibest.com.br

\section{Resumo}

Este artigo tem como objetivo demonstrar como o Índice de Desenvolvimento Humano, tem evoluído nos aspectos teóricos, metodológicos e políticos desde a publicação do seu primeiro relatório. Com este objetivo, foi efetuada uma ampla revisão da literatura, tanto na sua forma impressa, quanto na eletrônica, quando se pode notar que havia uma quantidade considerável de estudos tratando da questão, mesmo considerando-se o tempo relativamente curto de publicação dos relatórios. Neste estudo, aqueles trabalhos considerados mais importantes pelas suas abordagens foram avaliados e utilizados em sub-capítulo de Tese de Doutorado que se encontrava em elaboração. Do material inventariado e selecionado mostra-se a seguir, as alterações na metodologia utilizada na elaboração do índice, bem como, quais os pontos positivos e negativos apontados por estudiosos das mais diversas áreas do conhecimento. Estas análises críticas além da importância teórico-prática constituíram interessantes fontes de reflexão sobre a análise da qualidade de vida em Catalão (G0).

Palavras-chaves: IDH, Índice de Desenvolvimento Humano, Qualidade de vida.

\begin{abstract}
This article has as objective to demonstrate as the Index of Human Development, it has been developing in the theoretical, methodological and political aspects from the publication of its first report. With this I objectify, a wide revision of the literature was made, so much in its printed form, as in the electronics, when one can notice that there was a considerable amount of studies being about the subject, same being considered the time relatively short of publication of the reports. In this study, those more important considered works for its abordagens were appraised and used in sub-chapter of Thesis of Doctorate that met in elaboration. Of the inventoried material and selected it is shown to proceed, as it has been happening progresses in the methodology used in the elaboration of the index, as well as, which the positive and negative points pointed by specialists of the most several areas of the knowledge. These critical analyses besides the importance theoretical-practice constituted interesting reflection sources on the analysis of the life quality in Catalão (GO).
\end{abstract}

Key-words: IDH, Index of Human Development, Quality of life. 



\section{Introdução}

O Índice de Desenvolvimento Humano, desde a publicação do seu primeiro relatório, gerou e tem gerado reações a favor e contra os seus pressupostos teóricos, metodológicos e políticos. Embora, de uma maneira geral, seja desejável que o índice meça o desenvolvimento humano do modo mais completo possível, na prática isto não é possível devido ao grande volume de informação exigida mas, normalmente não disponível. Por isto, de acordo com os organizadores do Relatório de 1990, um índice que incorporasse muitas variáveis poderia tornar-se difícil para a sua interpretação e o excesso de informações afastaria a atenção dos pontos principais.

Por esta razão, segundo os formuladores do Relatório do IDH de 1990 (p. 12), as premissas básicas de suas análises estão concentradas em três aspectos fundamentais da vida humana: longevidade (expectativa de vida ao nascer), que não seja apenas viver mais, mas sim viver com qualidade; conhecimento, que significa não apenas ter acesso a educação, mas ter educação de qualidade que possibilite ao indivíduo ser produtivo na vida dentro da moderna sociedade contemporânea; uma vida decente, que segundo os formuladores do IDH representa a questão mais complexa, pois depende de o indivíduo ter acesso aos meios para prover a sua sobrevivência, de forma digna tais como: acesso a terra, ao crédito, a renda e outros recursos. A eleição destas dimensões foi justificada pelos formuladores do IDH, porque constituem os aspectos básicos do desenvolvimento humano, além do que, a maioria dos países dispõe de dados estatísticos aceitáveis para a sua avaliação. Por sua vez, entre tantas outras questões importantes para a humanidade, tais como a liberdade política, garantia dos direitos humanos e auto-estima, não são medidas pelo Índice.

A construção do IDH está baseada em uma aproximação da redução de desigualdades. Quer dizer, o desenvolvimento não é medido a partir do crescimento de uma variável, mas da redução da distância entre a variável e o seu máximo valor possível. Deste modo, é dada uma maior importância aos objetivos difíceis de serem alcançados. Os organizadores do Relatório de 1990 exemplificaram este ponto, partindo da premissa de que:

[...] to increase in 10 years the life expectancy requests a less considerable effort when this increases from 40 to 50, that when it varies from 60 to 70 years. To use the growth of the variable as indicator of the human progress, it would grant a larger importance for the simple earnings, more than in the first case in that the life expectancy increases in $25 \%$, considering that in the second case increases in 17\%. (RDH, 1990, p. 13). 
Por isto, é assumido um máximo de expectativa de vida ao nascer de 80 anos. Assim, um aumento na expectativa de vida de 60 para 70 anos representaria uma melhoria de 50\% (a diferença seria reduzida de 20 a 10 anos), ao invés de uma melhoria de $25 \%$. No primeiro caso, a diferença seria reduzida de 40 a 30 anos.

A versão do índice apresentado pela primeira vez em 1990, gerou um volume considerável de comentários sobre suas propriedades e metodologias utilizadas. Por isto, geralmente as principais críticas estavam relacionadas à construção do índice. Neste sentido, Hopkins (1991, p. 1470) comentou que os ponderadores iguais, pelos quais são divididos os indicadores para cada privação, nomeando uma ponderação de $1 / 3$ a cada ano, foi considerada arbitrária e, assinalou que: "no hay una racionalidad a priori que permita añadir la expectativa de vida y el alfabetismo. Es similar a sumar bananas y naranjas". Porém, mesmo que o IDH tenha sofrido crítica como esta, o objetivo inicial do IDH não mudou ao longo dos anos. Mas, a sua construção sofreu diversas modificações que tiveram como propósito corrigir alguns de seus defeitos iniciais, seja quanto as variáveis utilizadas, ou na fórmula utilizada no cálculo do índice. Com este objetivo, na seqüência é apresentada uma avaliação das características básicas do Índice, assim como algumas das críticas mais importantes que a ele tem sido feitas por diversos estudiosos do desenvolvimento humano.

\section{Análises críticas e contribuições ao índice de desenvolvimento humano}

Nesta revisão da literatura, inicialmente destacamos a análise elaborado por Mancero (2001, p. 20) que, em relação ao IDH, questionou o seguinte: "Vale destacar que éste no es el primer intento por construir um indicador que corrija los defectos del PIB "per capita" em la medición del desarrolo". Neste sentido, cita trabalho realizado por McGillivray (1991) que aponta exemplos de estudos alternativos, como o índice de "padrão de vida" elaborado por Drewnowski e Scott (1966); o "índice de desenvolvimento” de McGranahan et al. (1972) e o "índice de qualidade de vida física" (PQLI) organizado por Morris (1979). De acordo com o autor mencionado, o uso destes índices não prosperou, entre outras razões, por sua "redundância" com respeito ao PIB "per capita”, pois todos eles apresentavam uma correlação alta com a renda. Neste sentido, eles não constituíam, realmente, uma contribuição prática como medida do bem-estar e nem uma verdadeira inovação. 
Ainda, foi constatado que não existe nenhum acordo na literatura para pesar, de forma satisfatória, cada componente utilizado na metodologia de cálculo do IDH. Neste sentido, Kelley (1991, p. 315) sugeriu que a renda deveria ter uma ponderação maior, desde que pudesse ser usada para adquirir e para produzir saúde e educação. Em posição oposta, McGillivray e Write (1993, p. 183) sugeriram que a renda deveria receber uma ponderação menor, por ser ela somente um meio para obter o desenvolvimento humano e não ser um fim em si mesma como os outros dois indicadores. Hopkins considera que esta discórdia é uma das razões pelas quais o IDH não poderia se constituir num indicador maciçamente utilizado, como é o PIB. Em todo caso, como as divergências neste ponto são impossíveis de se resolver, estudiosos da questão recomendaram continuar usando ponderadores iguais e desenvolver esforços de investigação para melhorar a qualidade dos dados usados na construção do índice.

Em relação a ordenações das diferentes variáveis, Kelley (1991, p. 318) dentre outros, também considerou que o IDH era sensível à eleição de valores extremos para cada dimensão, o que afetava o desempenho de todos os países com respeito a cada privação. Por exemplo, se era utilizado um valor máximo mais alto para a educação, todos os países teriam um IDH menor. Quanto à questão da distribuição dos países na tabela de classificação, o autor comparou os resultados produzidos a partir da formula de calculo do PIB "per capita" e os gerados pelo IDH de 1990, e constatou que ocorreu a eliminação do parâmetro. Porém, quando ele aplicou o uso de logaritmos como meio de cálculo, constatou-se que ambos os indicadores geravam resultados bem parecidos até na distribuição do desenvolvimento humano, e que o logaritmo utilizado no cálculo do PIB constituía uma aproximação boa em relação aos resultados obtidos pelo IDH. Portanto, era verdadeira a afirmação de que outras variáveis do desenvolvimento humano é melhor distribuído do que a renda. Isto se deve ao fato de que alterações no cálculo da renda se mostraram altamente sensível para o resultado final do IDH.

No que diz respeito aos valores extremos das variáveis utilizadas no cálculo do IDH, uma das críticas mais generalizadas é que este não pode ser comparado intertemporalmente, já que os valores extremos utilizados para cada ano são distintos. Isto, porque segundo Trabold-Nubler (1991, p. 236) implicaria que um país que melhorasse sua condição de privação em uma proporção menor ao crescimento de valor máximo poderia, inclusive ver reduzido o seu IDH. Ainda, de acordo com os autores citados, outro defeito questionável acontece ao usar-se valores extremos das variáveis junto com a 
transformação dos indicadores entre os níveis [0 e 1] que o IDH utiliza. Por um lado, são escondidas as diferenças entre máximo e mínimo. Se por exemplo, se o país com maior esperança de vida conseguisse duplicá-la, o seu indicador de privação seguiria sendo igual a 1. Em outra situação, se todos os países aumentassem a expectativa de vida em 10\%, por exemplo, o IDH permaneceria igual e não mostraria avanço no desenvolvimento humano.

Devido a estas e outras criticas, os formuladores do IDH reconheceram as limitações que representava a utilização de um só número para dar conta de fenômenos multidimensionais. Porém, alegaram que a condensação de informações em um único índice tem demonstrado estar mais próxima da realidade no momento de avaliar o crescimento econômico e para decidir políticas, face à alternativa de se apresentar dados desagregados através de uma série de indicadores. Para eles, o conceito de "desenvolvimento humano" era diferente daquele de "crescimento econômico" e do "desenvolvimento econômico". Rao (1991) analisou estes conceitos e disse o seguinte:

O primeiro, considera o crescimento do produto sem importar se este permite, ou não, a ampliação das possibilidades de consumo; o segundo denota uma extensão de possibilidades de consumo de bens e serviços, mas não em outros âmbitos; o terceiro se refere à extensão de possibilidades de escolha além do âmbito do consumo, desde que inclua oportunidade de desenvolver e usar as capacidades humanas. (RAO, 1991, p. 1451).

Estas diferenciações de conceitos deixam claro que a renda, variável tradicionalmente utilizada para medir o desenvolvimento socioeconômico, constitui uma aproximação limitada a "capacidade de escolha" das pessoas. Por isto, a partir de dois argumentos principais os formuladores do IDH rejeitaram o ingresso de renda como indicador adaptado de desenvolvimento humano. O primeiro de tipo teórico, assinalando que o bem-estar de um país não depende da renda em si mesma, mas do uso que se faz dela. O segundo argumento está baseado na constatação empírica de que um alto nível de desenvolvimento humano pode ser administrado com uma renda "per capita" moderada e que uma renda "per capita" alta não garante o desenvolvimento humano satisfatório. Em resumo, conclui-se que o crescimento da renda não assegura o desenvolvimento humano.

Outras críticas foram direcionadas aos dados usados na construção do IDH. Assim, autores como Murray (1991, p. 6) e Srinivasan (1994, p. 238) analisaram a qualidade e a confiabilidade dos dados estatísticos com os quais o Índice era elaborado. De acordo com eles: "The three indicators that 
form part of IDH are built starting from information of questionable quality, above all, but not only, in what they refer to developing countries”. Os autores chamaram a atenção para o fato de que os dados utilizados na elaboração do IDH nem sempre se aproximam da realidade. Isto acontece porque os censos nacionais são, normalmente, realizados em intervalos de $10 \mathrm{em}$ 10 anos. Normalmente para anos intermediários e para os países que não contam com estas informações, são realizadas projeções elaboradas a partir de modelos matemáticos, os quais, em muitas ocasiões, geram resultados de uma realidade distante em relação aos anos nos quais os censos foram realizados. Por exemplo, muitos países não contam com informações mínimas de suas populações a respeito da expectativa de vida ao nascer e dos anos de escolaridade. Esta constatação tem vínculo direto com velocidade da dinâmica demográfica dos países subdesenvolvidos que apresentam muitas e rápidas mudanças em tempos relativamente curtos.

Os problemas com a medição da renda são também importantes, porque o que interessaria seria a renda medida em moeda corrente local e as compilações internacionais de dados apresentam, freqüentemente, divergências consideráveis nas suas estimações. As modificações introduzidas na variável renda utilizados no cálculo do IDH, foram criticadas em diferentes aspectos. Assim, de acordo com Trabold-Nubler (1991, p. 238) o uso de um limite máximo a partir do qual não é levado em conta o aumento de renda adicional, se contrapõe com a noção comumente aceita de que uma maior renda ampliaria as possibilidades de escolha das pessoas. O problema seria agravado na hora de se converter estes valores a uma unidade comum através do Índice de Paridade de Poder Aquisitivo (PPA). Neste sentido, Summers e Heston (apud SRINIVASAN) (1994, p. 238) criticaram os problemáticos procedimentos de extrapolação usados para calcular o Índice de PPA, pois de acordo com Murray (1991) o Banco Mundial só disponibilizam dados sobre esta variável para 57 países, fazendo com que para os outros países, os dados usados pelo PNUD, se pautasse em aproximações que não refletiam a real situação do poder de compra de suas populações. Estas deficiências geraram conseqüências sérias na hora de se estabelecer comparações intertemporais do IDH. Isto, porque a mudança de posição de um país no Índice ao longo do tempo poderia não ser devido a reais mudanças na situação de sua população, mas estar vinculado diretamente a revisão de seus dados (censos novos e revisões dos valores PPA) e para variações geradas artificialmente pelos modelos de estimação. Para ele, seria recomendado gerar o IDH utilizando valores observados e não estimados, especificando claramente os anos aos 
quais os dados se referem. Desta forma ficaria mais fácil entender a que se devem as mudanças no IDH, como também, permitiria mostrar a severa limitação de informação com as quais se conta para medir o desenvolvimento humano. A situação foi resumida da seguinte forma:

The year tendencies for year of IDH, just as it is made calculations and they are
presented now, they would not be interpreted. Small relative changes in the
taxes, be due to defects in the model and for real changes in the "per capita"
income. Larger changes in IDH of one year for the following don't correspond
to sudden accelerations in the socioeconomic development. But the introduc-
tion of a new information on mortality, education and values of PPA that will
radically affect the estimates of the countries. The movements of IDH are highly
correlated with the human development, but with the regularity of the censuses
and researches. (MURRAY, 1991, p. 6).

Por estas e outras criticas recebidas entre 1991 e 1993, o RDH de 1990 recebeu várias modificações no seu formato nos anos subseqüentes. No que diz respeito as versão original do IDH como nas suas edições posteriores, a longevidade era medida a partir da expectativa de vida ao nascer. O PNUD justificava a eleição desta variável através da idéia de que uma vida longa é por si só valiosa, pois possui uma forte associação deste indicador com a saúde e a nutrição das pessoas. Na área do conhecimento, o IDH de 1990 usava unicamente o nível de alfabetização dos adultos, considerado como indispensável à exigência básica para adquirir conhecimento.

Também, em relação aa renda real "per capita", terceiro componente do IDH, foi previamente modificada em três aspectos: Primeiro, para poder comparar a renda de países diferentes um do outro, estes, deveriam ser expressos nos mesmos termos, ou seja; de acordo com os bens que suas populações poderiam adquirir. Por esta razão, se corrigia a renda real (expressa em dólares) de acordo com a Paridade do Poder Aquisitivo (P.P.A). Segundo: o indicador teria que refletir a existência de ganhos decrescentes em escala no processo de transformação da renda em capacidades humanas. A opção escolhida para este fim foi usar o logaritmo no cálculo da variável. Por último, foi ponderado que não era necessário acrescentar mais renda a partir de um certo limiar $\left(\mathrm{y}^{*}\right)$ para se obter um padrão decente de vida. Então, a porção da renda que excedesse o limiar não seria levada em conta. Por isto, o valor de $\mathrm{y}^{*}$ foi determinado a partir da linha de pobreza de países industrializados, em dólares PPA, e foi calculada a partir da informação fornecida pelo Centro de Estudo da Renda de Luxemburgo (LIS). 
De acordo com Kelley (1991, p. 318): “[...] to cut the income starting from a certain point creates an asymmetry among the components of IDH, since a larger relative consideration is granted for the other two". Neste sentido, apontou que os ganhos decrescentes também estariam presentes na saúde e na educação, razões pelas quais também deveriam ser incorporados nestes indicadores de privação. Isto aconteceria porque quanto mais se aproxima de 100\%, ou ao nível máximo do 1, em uma das variáveis, mais difícil se tornaria de se conseguir atingí-lo. Veja-se o exemplo da alfabetização de adultos no Brasil, que com todas as políticas sociais desenvolvidas, não têm conseguido aproximar de $100 \%$.

Duas das principais conclusões do RDH de 1990, baseadas na relação entre o IDH e o PIB "per capita”, foram alvo de outras críticas. Em primeiro lugar, afirmou-se que outras variáveis do desenvolvimento humano avançara, consideravelmente, nos últimos trinta anos e que se apresentava melhor distribuído que a renda. Isto, porque a esperança de vida ao nascer e a alfabetização são variáveis importantes em seus limites superiores e não apresentam grandes disparidades em sua distribuição. Segundo, fora mencionado que a ordenação de países através da metodologia utilizada para a elaboração do IDH era muito diferente daquela obtida com a utilização do PIB "per capita”. Assim, não existiria uma relação automática entre o nível de renda "per capita” de um país e o seu nível de desenvolvimento humano. Ambas as afirmações foram tidas como centrais para os Relatórios posteriores, cuja mensagem principal era homogênea: a de que o desenvolvimento humano seria perfeitamente possível sem a necessidade de que a renda alcance níveis "per capita” muito elevados. Com relação a primeira conclusão, McGillivray e Write (1991) explicaram as duas razões pelas quais o desenvolvimento humano seria melhor distribuído que a renda. Com base nos dados do Relatório do IDH de 1991, os autores mencionados mostraram que a renda mais alta era vista em cerca de $97 \%$ do seu valor e não em $100 \%$. Para eles:

It is natural that when included these varied in the calculation of IDH are reducing the own inequality of the income. On the other hand, when applying won decreasing to the income and" to cut him/it" starting from a certain landing is reduced, drastically, the inequality in the distribution of the same, since any extreme value is eliminated. (McGILLIVRAY; WRITE, 1993, p. 183).

A verificação da segunda conclusão tem recebido atenção considerável por parte de estudiosos do desenvolvimento humano, já que dela de- 
penderia o grau de aporte que representa o IDH frente ao PIB "per capita”, na medição do desenvolvimento humano. A respeito, uma análise muito ilustrativa foi encontrada em McGillivray e Write (1991, p. 185). No artigo mencionado, é avaliada a correlação existente entre o IDH de 1991 e os indicadores que o conformam, inclusive o PIB "per capita”. Os resultados mostram que para as pequenas amostras de países com um nível semelhante de desenvolvimento humano, o grau de correlação entre o Índice e outros indicadores era reduzido e não se evidenciava uma duplicação de informação. Porém, ao usar a amostra completa de países, a correlação é bastante alta, sobretudo entre o IDH e o PIB "per capita”. Adicionalmente, os autores avaliaram a sensibilidade do IDH ante os erros de medição, concluindo que o índice é consistente a estes tipos de erros, por que os resultados obtidos não se devem a uma causa específica. Em resumo, o IDH parece ser útil para distinguir níveis de desenvolvimento humano entre países de situação semelhante, mas não gera ordenações significativamente diferentes dos PIBs "per capita" quando os países comparados diferem, consideravelmente, em seus graus de desenvolvimento humano.

Adicionados a crítica mencionada anteriormente, Trabold-Nubler (1991) arrolou outros dois defeitos importantes para o IDH de 1990. O primeiro, referia-se à forma pela qual o indicador de conhecimento era construído pois, esta dava a falsa impressão de que a variável pesava respectivamente em 2/3 e 1/3 no cálculo do indicador. Isto, porque os verdadeiros ponderadores de conhecimento são determinados pelas diferentes oportunidades surgidas ao longo da vida por uma pessoa durante a sua alfabetização e os anos de escolaridade. O autor expôs a questão da seguinte forma:

The knowledge indicator is calculated twice for a country with 99\% of literacy, and using a possible minimum case of value for the years of education (6.2), and in another possible maximum case of value (12.2). In the first case, IDH takes a value of 68.1 , that he/she just rises to 70,1 when the years of education are the largest the possible. Like this, in the mentioned sample, the literacy has a larger consideration executes to $90 \%$. To correct this problem, it is suggested to unify the consideration of each variable for the level 0-1. (TRABOLD-NUBLER, 1991, p. 236).

A solução apontada foi adotada rapidamente pelo PNUD e, em 1992, passou-se a transformar ambos os componentes do indicador de conhecimento também ao nível (0 - 1). As modificações, exclusivamente, se atinham à forma de construção dos indicadores de conhecimento e de padrão de vida. Com respeito ao primeiro, foi considerado que a alfabetização é uma 
exigência básica para que uma pessoa possa adquirir e utilizar informações, pois há muito mais elementos que tomam parte do conhecimento e da comunicação. Por esta razão, para o indicador de conhecimento, a média de anos de educação sugerida, seria calculada a partir da seguinte proposta:

Conhecimento $=2 / 3$ * alfabetização de adultos $+1 / 3$ * anos de educação ( $\geq 25$ anos)

Por outro lado, foi considerado que uma nova metodologia seria necessária para que se pudesse construir o indicador de nível de vida, baseado na utilidade derivada da renda. A nova formulação buscou modelar, explicitamente, os ganhos decrescentes que previamente tinham sido aproximados em função logarítmica. Esta nova formulação permitiu nomear valores de parâmetros diferentes de acordo com os graus de renda. A idéia era diminuir a importância da renda à medida que esta aumentasse, mas de um modo menos drástico que o apontado em 1990, quando era assumido, implicitamente, que os ganhos em escala eram absolutos e ignorava qualquer renda superior ao patamar determinado pela linha de pobreza dos países industrializados.

O segundo defeito do IDH de 1991 tinha a ver com a forma pela qual os ganhos decrescentes referentes a mais valores monetários tinham para a sua conversão em renda efetivamente utilizada na melhoria da qualidade de vida. Por um lado, o autor considera que a penalização da renda "per capita" alta era muito severa e citou, como exemplo desta distorção pois, a diferença de \$15.230 no PPA entre o E.U.A. e o Brasil, no indicador final da renda resultava em uma diferença de apenas $\$ 450$. Também, foi apontado que a fórmula usada violava o princípio de ganhos decrescentes para certos níveis de renda. Trabold-Nubler (1991) demonstrou isto da seguinte forma:

[...] for the fact that the first dollar of each level of income has a larger marginal usefulness than the last dollar of the previous level. Additionally, it is verified that the first additional dollar in a degree of income contributed less to the usefulness that the first additional dollar in the degree of superior income. (TRABOLD-NUBLER, 1991, p. 237).

Para corrigir estas limitações, o autor sugeriu a utilização da fórmula original de Atkinson para a função de utilidade da renda, escolhendo um único valor para o parâmetro de ganhos de escala $(\mathrm{e}=0,5)$ independente do nível de renda. 
Embora estas tenham sido as únicas modificações feitas ao Índice em relação metodologia utilizada em 1990, as notas técnicas dos Relatórios entre 1991 e 1993 apresentaram uma série de extensões ao índice. Entre eles, se encontravam análises de sensibilidade do IDH e da distribuição da renda, a construção de índices corrigidos pelas disparidades entre gêneros, e uma análise do avanço no desenvolvimento humano comparando o IDH entre dois períodos. Embora no Anexo do RDH de 1993 tenha sido feita uma revisão destas e outros críticas, não foram feitas modificações substanciais na forma de se calcular o IDH até o ano seguinte.

Como será visto a seguir, as modificações introduzidas no ano de 1994 corrigiram alguns defeitos mais significativos no índice, especificamente, a comparabilidade intertemporal (em 1994). Assim, os Relatórios a partir de 1994, se preocuparam, por exemplo, em mostrar como se alteraria o desempenho dos países se a renda fosse corrigida por meio do coeficiente de Gini. Apesar da constatação da importância desta comparação, a ausência de dados confiáveis e atualizados para a maioria de países evitou que este tipo de consideração fosse incorporado, permanentemente, no cálculo do índice.

Com este objetivo, em 1994 foram efetuadas três mudanças no IDH. A mais importante situava-se na forma de fixar os valores extremos para as três variáveis usadas. Em anos anteriores, as notas técnicas já tinham apontado a importância de se usar valores extremos iguais para os anos nos quais se realizavam comparações de índices. De acordo com essas considerações, para 1994 foram fixados valores extremos normativos. Os valores mínimos corresponderiam, historicamente, ao observado por um período aproximado de 30 anos, considerando que os máximos eram escolhidos de acordo com a expectativa de crescimento das variáveis por um período prolongado. Os novos patamares passaram a ser: expectativa de vida ao nascer, entre 25 e 85 anos; alfabetização de adultos, entre 0 e 100\%; média de anos de escolaridade, entre 0 e 15 anos; renda, entre 200 e 40.000 dólares PPA.

Por isto, em 1994 ocorreram mudanças nos valores da renda usadas como patamares $\left(\mathrm{y}^{*}\right)$, a partir do qual diminuíam os ganhos em escala. Nos Relatórios anteriores, o patamar para a linha de pobreza utilizada tinha, como referência, aquele verificado em países industrializados e calculados a partir dos dados do LIS. A partir daquele ano, o valor do patamar foi fixado pela média do PIB "per capita” mundial em dólares através do Índice de Paridade de Poder de Aquisição (PPA), que correspondia a \$5.120 para o IDH de 1994. Por último, uma mudança menos mencionada no Relatório de 1994 tinha a ver com a fonte de dados para os valores de PPA. Até aquele 
ano a única fonte usada tinha sido as "Penn World Tables", elaboradas a partir do trabalho de Summers e Reston (1991). No Relatório de 1994, foi utilizada, preferivelmente, estimação de moedas contida em relatórios do Banco Mundial.

No Relatório do ano de 1995, outras modificações foram introduzidas como aquelas relacionadas as ponderações do indicador de conhecimento. Neste sentido, a partir de 1995, ocorreram duas mudanças no IDH que não foram consideradas como significativas. Primeiro, ocorreu a substituição da média de anos de educação, do indicador de conhecimento, por uma taxa de matrícula combinada para o primário, o segundo e o terceiro graus, com possíveis valores nos níveis [0\%, 100\%]. Embora o Relatório de 1995 justifique esta mudança pela dificuldade de conseguir os dados na opção anteriormente utilizada, indiretamente era corrigido o defeito de ponderação assinalado por Trabold-Nubler (1991, p. 237) no que diz respeito a renda. Por isto a fixação do valor mínimo da renda em 100 dólares PPA, para manter a coerência com o IDH por gênero (o IDG), já que a renda mínima feminina observada fora de 100 dólares PPA.

Por sua vez, Castles (1998, p. 831) mostrou que muitas das afirmações e conclusões às quais já se chegara sobre os diferentes RDHs eram resultados de uma interpretação ruim das estatísticas, tanto dos dados utilizados quanto dos valores obtidos para o IDH. O autor faz notar, em primeiro lugar, que o tratamento de alguns indicadores estatísticos não são rigorosos. Os exemplos são abundantes, tanto no artigo mencionado quanto em um trabalho posterior publicado em 1999. O autor inclusive, assinalou que se analisava, equivocadamente, o tipo de informação que provêm dos mesmos Índices gerados no Relatório. Cita, por exemplo, o caso do IPH-2 de 1998, onde se confunde a proporção de pessoas que em 1995, não sobreviveram até os 60 anos, com aquele das pessoas de uma população hipotética, nascida em 1995, a qual não sobreviveria até os 60 anos, se ela estivesse sujeita à taxa de mortalidade de 1995.

Tradicionalmente, o RDH tem apresentado uma ordenação de países de acordo com seu grau de desenvolvimento humano, especificando a posição relativa do país segundo seu PIB ajustado por PPA. Em geral, quando a posição relativa do país é melhor dentro do IDH que no PIB, supõe o Relatório que este país, realmente, conseguiu transformar sua renda em desenvolvimento humano. No caso oposto, foi considerado que o país não foi eficientemente capaz de usar a sua renda para obter desenvolvimento humano. 
Avaliar a situação de um país baseada na diferença de posições relativa entre IDH e PIB, pode conduzir a sérios erros. Por meio deste mecanismo, o Relatório de 1998, cita, que Madagascar e Maurício constituíam exemplos de êxito e fracasso respectivamente no uso da renda para gerar um efetivo desenvolvimento humano. Não obstante, Castles (1998, p. 832) demonstrou que esta avaliação estava mesmo longe da realidade, como foi por ele observado em uma série de indicadores econômicos e sociais destes dois países. Assim é que enquanto Madagascar tivera um crescimento econômico e um desenvolvimento humano sem precedentes, Maurício permanecera estagnado em ambos os aspectos.

Em outro exemplo, o autor aproveita o caso de Omã para mostrar a seriedade dos erros que podem acontecer quando é ignorada a qualidade dos dados usados no cálculo do IDH. Através de vários anos, o Relatório apresentou este país como um caso de limitado desenvolvimento humano, apesar de contar com recursos suficientes. Entretanto, a reduzida pontuação que obtivera dentro do IDH, não refletia a realidade do país. Isto era apenas produto de um uso errôneo de projeções para os dados, pois enquanto o PNUD supunha uma taxa de alfabetização de $30 \%$ e valor de 0,9 para anos médios de escolaridade, a UNESCO reportava que neste país a alfabetização era de $60 \%$ na educação primária.

Adicionalmente, o autor mencionado, refutou o fato de que países com pontuações semelhantes no IDH têm níveis semelhantes de desenvolvimento humano, como assume o Relatório de 1998 ao comparar Costa Rica com a Coréia. O IDH não considera alguns fatores relevantes para o desenvolvimento humano, como o maior tempo livre de que desfrutam os coreanos, graças ao enorme crescimento de sua renda, além do fato de que o nível educacional dos adultos na Coréia é muito maior que o de um adulto na Costa Rica. Nas palavras de Kelly (1991, p. 231): "As well as no there is a perfect correlation between GDP and the human development, it doesn't exist, or it cannot be assumed, that this exists between IDH and the human development."

Um dos trabalhos que foi previamente analisado por especialistas do PNUD, para possíveis correções da metodologia empregada, foi a fórmula proposta por Noorbakhsh (1998, p. 517) para o qual o ÍDH-Modificado teria sido desenvolvido para superar três críticas comuns ao IDH. Para ele, estas questões constituíam em: "Não dar importância suficiente à renda elevada, não aplicar o princípio de ganhos decrescentes a outros componentes do índice e ser sensível aos valores extremos utilizados em seus cálculos". Por 
isto, uma das críticas que seriam incorporadas no Relatório de 1999, referiase a forma de cálculo para o indicador do nível de vida. Tal como tinha sido apontado em várias críticas, a formulação anterior (baseada no trabalho de Atkinson) penalizava excessivamente a renda alta. Então, a nova fórmula para a variável renda eliminaria o patamar máximo e incorporaria os ganhos decrescentes.

Em função das inúmeras críticas efetuadas e para aperfeiçoar a metodologia de cálculo do IDH, o PNUD convidou novamente em 1998, Amartya Sen para que efetuasse alterações na fórmula de cálculo, a partir das observações emitidas pelos críticos. Em 1999 o PNUD divulgou importantes mudanças metodológicas no IDH, sendo que a principal se referia à sistemática de calcular a dimensão renda "per capita". De acordo com o que consta no RDH de 1999, são três as vantagens desta nova formulação:

Em primeiro lugar, o desconto para a renda não é tão forte quando ele era baixo para a opção anterior, de forma que a renda tenha uma maior importância relativa na determinação do IDH. Em segundo lugar, a complicação é evitada ao separar os subgrupos que, alem de não ter uma sustentação teórica válida, violava o princípio de ganhos decrescentes. Por último, o crescimento do desconto colocado na nova fórmula é menos pronunciado, dito de outro modo, isto acontece para valores maiores que antes. Então, um crescimento do PIB em países de renda média teria uma maior importância que antes sobre a medição do desenvolvimento humano. (RDH, 1999, p. 16).

Apesar das alterações introduzidas pelo PNUD, continuaram ainda a existir questionamentos sobre a capacidade desta nova fórmula dar conta da importância que teria um crescimento da renda no desenvolvimento humano. A este respeito, Leon e Espíndola (2004) calcularam o IDH para o Chile, supondo diferentes taxas de crescimento para o PIB "per capita" no período compreendido entre 1990 e 1997. De acordo com eles:

Se tivesse ocorrido um crescimento da renda em 50\%, ela se apresentaria no cálculo do IDH em um patamar menor ao efetivo e teria um IDH igual a 0,831, ao invés do índice atual do país que era de 0.844. Mas, até mesmo, se o PIB não tivesse crescido naquele período, o IDH seria 0.820. (LEON e ESPÍNDOLA, 2004, p. 3).

Por isto o autor comenta que o IDH do Chile se mostrou pouco sensível às modificações introduzidas pelo PNUD, para avaliar as variações na renda e que, o crescimento da renda não tem um papel suficientemente importante na determinação do IDH. 
Nesta mesma linha de análise, ou seja, buscando caracterizar a fragilidade do IDH calculado de acordo com metodologia desenvolvida pelo PNUD, Lemos e Jiménez (1999, p. 1) afirmaram que a sua grande fragilidade consiste em não incorporar os aspectos distributivos do crescimento do produto gerado no sistema econômico, muito embora os relatórios do PNUD, freqüentemente, se referiram à equidade e a sustentabilidade do desenvolvimento. Isto porque, segundo autor, o índice se mostra mais adequado às economias desenvolvidas, nas quais inexiste a pobreza absoluta definida como: “[...] a incapacidade de um indivíduo satisfazer os padrões mínimos de carências estabelecidas em uma determinada sociedade e onde as desigualdades na distribuição pessoal e espacial da renda nacional tendem a ser menores do que nos países subdesenvolvidos”. Com objetivo de contribuir para a melhoria da metodologia utilizada, Lemos (2002) propôs uma nova fórmula e, para isto, argumentou que:

Chamamos esse novo indicador de IDHA. Mostramos que o IDH e o IDHA experimentaram consideráveis melhorias durante o período de 1970 a 1991, mas os valores do segundo, sempre se situam abaixo dos valores do primeiro. A explicação é devida ao fato de que a introdução dos indicadores de pobreza e desigualdade na distribuição da renda, atenua o efeito positivo da melhoria verificada na renda per capta (sic). (LEMOS, 2002, p. 3).

Porém, há de se destacar que também existem pontos nos Relatórios divulgados e nos IDHs, que são considerados como positivos por muitos autores. Isto, porque eles abrem discussões sobre questões que, até recentemente, eram tratadas de forma isolada no contexto da maioria dos países da comunidade internacional. Avaliando esta perspectiva, Carvalho (1997) considerou que o IDH é uma linguagem que tem tudo para se universalizar, trazendo para esse campo semântico as controvérsias sobre as questões brasileiras, a consolidação da democracia e a superação dos índices alarmantes de desigualdade. Para ele:

É uma possibilidade que o autor considera interessante derivada da própria natureza da linguagem adotada pois, em virtude da sua característica, digamos, técnica, o IDH deverá mobilizar a inteligência estocada nas universidades e nos centros de pesquisa, que se mantiveram até aqui, em uma posição discreta. (CARVALHO, 1997, p. 43).

Pode também ser observado, que o PNUD, levou a cabo uma longa série de correções no ÍDH desde a sua criação. Porém, muitos dos seus defeitos, apontados na literatura, continuam presentes. Por conseguinte, não se- 
ria de estranhar, que nos próximos anos o Índice sofra novas modificações, com as quais tenderia a, obviamente, reiterar os problemas de comparabilidade intertemporal de seus resultados. São vários os estudos publicados que propõem versões corrigidas do IDH e isto, permite avaliar os tipos de modificações que o PNUD, provavelmente incorporará em publicações futuras.

Assim, as mudanças ocorridas no IDH, são reflexos da necessidade de se desenvolver e responder a uma conjuntura internacional marcada pela inserção competitiva do modelo ocidental de qualidade de vida em um mundo globalizado. Ou seja, busca-se a idealização de um mundo onde ocorreria a aproximação do que se considera ter um nível de qualidade de vida adequado. Também, é possível constatar que, embora o objetivo inicial do ÍDH não tenha mudado ao longo dos anos, sua construção sofreu diversas modificações, seja quanto as variáveis utilizadas, seja no cálculo do índice, com o propósito de corrigir alguns de seus defeitos iniciais.

Com respeito ao Índice, os questionamentos têm sido dirigidos aos seus aspectos metodológicos: variáveis consideradas, ponderadores utilizados, irrelevância de resultados etc. Assim como as fontes de informação utilizadas e suas implicações empíricas. As críticas dirigidas ao Relatório como tal se referem, usualmente, ao apontamento de conclusões que muitas vezes não são respaldadas pelas informações estatísticas utilizadas, e isto é um sério desafio.

O IDH passou apresentar, portanto, novos fatores para a compreensão de que o importante para o bem-estar humano é a oportunidade de ampliar sua capacidade, eleger e utilizar esta capacidade em prol das atividades no cotidiano da vida. Neste sentido, Miquel (1997) considerou que alguns pontos são positivos nesta ferramenta de aferição da qualidade de vida, afirmando que:

O IDH permitiu que fossem colocadas no centro do debate internacional, aspectos tais como a pobreza, as disparidades sociais e econômicas, estreitando-se a relação entre crescimento econômico e bem-estar. Facilitou a análise das políticas públicas governamentais e as conseqüências daquelas na vida dos cidadãos. [...] É uma ferramenta excelente para avaliar aspectos estruturais, mas lhe falta sensibilidade para medir as mudanças conjunturais. A criação do IDH contribuiu também para chamar a atenção sobre as deficiências na coleta e processamento de dados na área social. (MIQUEL, 1997, p. 16).

Talvez este aspecto, seja um dos mais relevantes, pois abre possibilidades de discussões políticas sobre a premência de se acompanhar, de perto, as mudanças nas condições de vida da população, bem como sob o ponto de 
vista ideológico-filosófico que podem, no futuro, alterar o modelo de desenvolvimento socioeconômico das sociedades.

Nesta mesma direção de análise, Bocayuva (1997, p. 49) assinalou que há alguns pontos positivos no IDH. O primeiro é que ele tenta ser um instrumento de análise comparativa entre vários países e realidades diversas, pois ele está ligado a uma perspectiva de universalidade. O segundo está em que, pela sua metodologia de coleta, tratamento e formulação dos dados, ele permite algum grau de intervenção da sociedade, o que é fundamental. $\mathrm{O}$ terceiro é que o relatório apresenta alguns textos e tópicos que derivam da ação ou da preocupação da sociedade, como nas questões: racial, de gênero, do trabalho infantil, de ocupação, nível de renda, etc. Por último há a questão do debate em relação à elaboração dos indicadores de desenvolvimento humano, pois ele aparece oficialmente em discussões pelos Estados, pelas sociedades e nas conferências que a própria ONU tem contactado.

Na linha de análise crítica a respeito do IDH, poderíamos enumerar ainda, uma lista considerável de estudos sobre as principais proposituras do ÍDH. Mas aqui, optamos por destacar alguns trabalhos que em função de suas contribuições foram considerados relevantes pelas propostas de avanço que eles contêm para melhorar a fórmula de cálculo do Índice. Assim, citamos inicialmente os estudos elaborados por Noorbakhsh (1998) que, a partir da avaliação das críticas formuladas por outros estudiosos do IDH, propôs o MDHI. Também, Hicks (1997) a partir da avaliação das premissas básicas utilizadas na metodologia do IDH, propôs o IAHDI, que comparado com o coeficiente de Gini buscou demonstrar como ficariam classificados os países em relação ao apresentado na tabela do IDH de 1996. Por sua vez, Pérez (2000) estudou a estrutura mundial da pobreza após dez anos da publicação do primeiro relatório do PNUD, contendo o IDH. O autor faz uma interessante discussão a respeito do papel ideológico desempenhado pelo IDH, afirmando que a sua feitura tem um enfoque social democrata, bem como aponta alguns pontos positivos e negativos do mesmo.

Outro artigo interessante foi elaborado por Opazo (2000) que avaliou a colocação do sujeito como objeto do desenvolvimento humano apontando, para isto, as diversas facetas apresentadas pelo PNUD no Relatório anual do IDH. Segundo o autor o mundo atual se encontra frente a um princípio moral, pois ainda na atualidade, relatórios das principais organizações financeiras do mundo apontam áreas prioritárias, opções, temas, problemas e desafios, mas não propõem nenhuma estratégia palpável para a solução dos grandes questões sociais e ambientais. Neste sentido, o autor afirma que o 
IDH aponta para uma nova convicção: a de que é possível satisfazer as necessidades humanas, porque nunca na história humana os homens tiveram tanto controle sobre a natureza. Por isto afirma ainda que, o debate tem proporcionado excelentes análises, opções políticas, recomendações aos governos, propostas de mobilização da sociedade civil e servido de aporte para as conferências sobre as principais questões mundiais.

Destacou-se também, o estudo elaborado por Jahan (2001) que buscou demonstrar a importância do IDH como instrumento de medida das condições de vida dos homens. Para ele, pode até haver muitos erros na metodologia utilizada pelo PNUD para aferí-lo, porém esta ferramenta é importante porque permite acompanhar a trajetória das condições de vida de praticamente toda a população mundial. Daí, este autor destacar a importância das contribuições feitas por membros do escritório central do PNUD e por intelectuais/acadêmicos, para o seu aperfeiçoamento.

É também relevante, o estudo elaborado por Keinert, T. M. M. et al. (2002) que tratou dos sistemas locais de informação e a gestão pública da qualidade de vida nas cidades. O estudo é importante porque demonstrou ser necessário ter arquivos municipais bem estruturados e organizados sobre a produção, armazenamento, coleta, análise e disseminação de informações relacionadas a qualidade de vida em nível local. Por sua vez, Qizilbash (2002) produziu um artigo mostrando as diversas dificuldades teóricas e metodológicas presentes no Relatório do IDH, entre elas, a questão da coerência de suas medidas e a sua proposta de multidimensionalidade e universalismo que não considera os aspectos culturais presentes em todo o mundo.

\section{Considerações finais}

Em resumo, são vários os erros e acertos que têm sido cometidos na interpretação dos resultados do IDH. Estes erros decorrem de causas diferentes. Dentre eles, o uso de dados poucos seguros; a dependência excessiva do IDH em relação ao PIB, que ignora outros fatores, e a suposição de que o IDH é sinônimo de desenvolvimento humano. Mas, os acertos também são importantes. Por exemplo, temos o significado do índice para a formulação de programas, para a reflexão a respeito das reais condições sociais vividas por uma dada sociedade e desta, para com outras, espalhadas pelo mundo todo. Desta forma, os indicadores de desenvolvimento humano representam a possibilidade e a sinalização do quadro social atual, a definição de prio- 
ridades e o monitoramento dos avanços e recuos dos diversos segmentos sociais ao longo da história.

Assim, uma sugestão que poderia ser dado aos produtores do PNUD, seria a de que eles buscassem estabelecer um índice objetivando medir o nível de ocupação (empregabilidade) da população economicamente ativa por país. Considera-se ser este ponto importante, porque não se pode pensar em qualidade de vida / desenvolvimento humano, se no mundo atual, cada vez mais, esta questão tem se constituído na preocupação prioritária para os homens.

A avaliação feita serviu também para evidenciar a significância internacional de todas as discussões contempladas pelo desenvolvimento humano. É justamente esta multiplicidade de discussões que coloca a temática do IDH como algo transdisciplinar, com importantes reflexões filosóficas, econômicas, sociais e políticas que se espera tenha impactos positivos na vida das pessoas.

\section{Referências}

BUENO. E. P. Dinâmica demográfica e a conformação sócio-espacial da cidade de Catalão (GO): uma análise dos níveis de desenvolvimento humano entre 1970 e 2000. (Tese de Doutorado em Geografia). Rio Claro (SP): UNESP, 2006. 385 p.

HOPKINS, M. Human development revisited: a new UNDP Report. World Development, v. 19, n 10. p. 1469 - 1474, 1991.

KELLEY, A. C. The human development índex: handle with care. Population and Development Review. v. 17, n 2. p. $315-324,1991$.

McGILLIVRAY, M. e WHITE, H. Measuring development? The UNDP's human development index. Journal of International Development, v. 5. n 2, p. 183 - 192, 1993.

MURRAY, C. Development data constraints and the human development index. United Nations Research. Institute for Social Development, Discussion Paper, 25. 1991.

SRINIVASAN, T.N. Human development: a new paradigm or reinvention of the wheel? American Economic Review. v. 84. n 2. p. 238 - 243, 1994.

BOCAYUVA, P. C. C. Entrevista. Revista Proposta (FASE), n 73. ano 26. p. 48 - 57. junho/agosto. 1997.

CARVALHO, M. A. R. Entrevista. Revista Proposta (FASE). Ano 26, n 73, p. 42 - 47, julho/agosto de 1997. 
CASTLES, I. The mismeasure of nations: a review essay on the human development report. Population and Development Review. v. 24. n 4. p. 831 - 845, 1998.

HICKS, D. A. The inequality-adjusted human development index: a constructive proposal. Wold Development, v. 25, n 08, p. 1283 - 1298. 1997.

JAHAN, S. Measuring living standard and poverty: human development index as an alternate measure. 14 p. 2001. Disponível em www.umass.edu. Acessado dia 07/05/2003 às 10h04.

KEINERT, T. M. M. et al. Sistemas locais de informação e a gestão pública da qualidade de vida nas cidades. Terra Livre, São Paulo, ano 18, v. 1, n 18, p. 115 - 132, Jan/Jun. 2002.

LEMOS, A. M. Desenvolvimento humano e inclusão social no Brasil. Disponível em: www.unit. br/graduacao/economicas: acessado em 20/11/02 às $17 \mathrm{~h} 05$.

LEMOS, A. e JIMÉNEZ, R. A. F. Distribuição de renda, pobreza e desenvolvimento humano no Brasil. Disponível em www.unit.br/graduacao/economicas: acessado em 22/07/2002 às 22h12.

LEON, A. e ESPÍNDOLA, E. Nota técnica acerca del índice de desarrolho Humano del Pnud. CEPAL. Santiago/Cl. Março, 2004. Disponível em: http://www.eclac.cl/cgi-bin/getProd.asp?xml=/ publicaciones/xml/1/14481/P14481.xml\&xsl=/tpl/p9f.xsl. Acessado em 20/05/2005.

MIQUEL, C. A. O Índice de desenvolvimento humano: uma proposta conceitual. Revista Proposta (FASE). Ano 26, n 73, p. 10 - 19, junho/agosto. 1997.

NOORBAKHSH, F. The human development índex: some technical issues and alternative indices. Journal of International Development. v. 10, n 5, p. 589 - 606, 1998.

ONU - United Nations Development Program. 1990: Human Development Report. Concept and measurement of human development.

. United Nations Development Program. 1991: Human Development Report. Financing human development.

. United Nations Development Program. 1993: Human Development Report. People’s participation.

. United Nations Development Program. 1994: Human Development Report. New dimensions of human security.

. United Nations Development Program. 1997: Relatório do Desenvolvimento Humano. Desenvolvimento humano para erradicar a pobreza.

. United Nations Development Program. 1999: Relatório do Desenvolvimento Humano. Globalização com uma Face Humana.

OPAZO, A. El sujeto del desarrollo humano. VIII Simposium de de Educación "Educar para construir el sueño: ética y conocimiento en la transformación social. Anais.... 17 p. 2000. Disponível em www.gdl.iteso.mx/event/simpeduc/index.htm: acessado em 05/02/2001 às 15h23. 
PEREZ, F. R. El plan de remodelación de barrios de Madrid. Conceptualización, metodología y fuentes documentales para su estudio. Estudios Geográficos, Tomo L, n 194, Enero-marzo. p. 137 - 150, 1989.

QIZILBASH, M. On the measurement of human development. 16 p. 2002. Disponível em: www. hdr.undp.org/doc: acessado em 05/05/2003, às $21 \mathrm{~h} 48$.

Edir de Paiva Bueno - é Prof. Dr. do departamento de geografia do Campos Catalão da Universidade Federal de Goiás

Recebido para publicação em agosto de 2007

Aceito pra publicação em outubro de 2007 


\title{
Oscilação das chuvas na porção centro oeste do estado de Mato Grosso, entre os anos de 1996 a 2001
}

\author{
Oscillations des pluies dans la portion centre-ouest de l'etat de Mato Grosso, entre les annees 1996 \\ et 2001.
}

\author{
Romário Rosa de Sousa Universidade Federal de Mato Grosso \\ romarioufg@yahoo.com.br \\ Luiz Gonzaga Toledo - Universidade Federal de Mato Grosso \\ romarioufg@yahoo.com.br
}

Doroty Queiroz Topanotti - Universidade Federal de Mato Grosso

romarioufg@yahoo.com.br

\section{Resumo}

0 presente trabalho analisou a oscilação das chuvas anuais ocorridas na porção Centro-Oeste do Estado de Mato Grosso entre os anos de 1996 a 2001, identificando os municípios que tiveram mais e menos acúmulos pluviométricos, com posterior geração de mapas de isoietas através de técnicas de interpolação no programa de Surfer versão 8, da Golden Software Inc. Os maiores valores pluviométricos foram registrados nos anos de 1998 e 1996, com somas de 2300 a $2350 \mathrm{~mm}$, abrangendo os municípios de Comodoro, Nova Lacerda, Campos de Júlio, Sapezal e Tangará da Serra. Já no ano de 1999, registrou-se menor valor pluviométrico com $1900 \mathrm{~mm}$, nos municípios de Comodoro e Nova Lacerda. A variabilidade pluviométrica ocorreu ao longo dos seis anos de estudo, período em que a chuva foi bem irregular, durante todos os anos analisados. Com os resultados obtidos das análises dos mapas de isoietas de 1996 a 2001, identificou-se que preferencialmente, as chuvas ocorreram em maior quantidade nas porções Oeste e Norte, sendo que as menores quantidades chuvosas registraram-se nas porções Leste e Sul.

Palavras-chave: Oscilação, chuva, precipitação, variabilidade, distribuição.

\section{Résumé}

Le présent travail a analisé l'oscillation des pluies annuelles qui ont été tombées dans la portion Centre-Ouest de l'Etat de Mato Grosso, entre les années de 1996 à 2001, identifiant les districts qui ont été plus ou moins des accumules pluviométriques, avec postéurieure génération des cartes des isoyètes à travers des téchniques d'interpolation dans le programme Surfer, version 8, de la Golden Software Inc. Les plus grandes valeurs pluviométriques ont été enrégistrées dans l'années 1998 à 1996, avec des additions de 2300 à 2350mm, renfermant les districts de Comodoro, Nova Lacerda, Campos de Júlio, Sapezal et Tangará da Serra. Néanmoins dans l'année 1999 nous l'avons enregistrée une petite valeur pluviométrique avec $1900 \mathrm{~mm}$, dans les districts de Comodoro et Nova Lacerda. La variabilité pluviométrique a eu lieu le long des 6 anées d'études, où la pluie a été bien irregulière, pendant toutes les années analysées. Avec les résultats obtenus des analyses des cartes des isoyètes de 1996 à 2001, nous avons identifié que préférentiellement, les pluies ont tombées en majeure quantité dans les portions Ouest et Nord, étant donnée, que les mineures quantités pluvieuses ont été enrégistrées dans les portions Est et Sud.

Mots clés: Oscillation, pluies, précipitation, variabilité, distribution.

Boletim Goiano de Geografia $\quad$ Goiânia - Goiás - Brasil

v. 27

ก. 3

p. $71-89$

jul. / dez. 



\section{Introdução}

No mundo atual, existem milhões de pessoas que sofrem com os efeitos climáticos, especialmente aquelas das regiões semi-áridas, onde muitos não possuem recursos que permitam o uso de tecnologia capaz de superar as limitações predominantes 2004). Entre os diversos meios necessários à vida, o clima tem características fundamentais.

Durante os primeiros tempos históricos, o testemunho climático consistia em lendas. As compreensões do homem sobre os fenômenos do tempo atmosférico eram controladas pelos deuses, até por volta do quinto século antes de Cristo, quando os gregos começaram a fazer observações sistemáticas dos fenômenos meteorológicos (2002).

Vivemos numa época de grandes transformações ambientais, na qual as alternâncias de períodos chuvosos e secos assumem proporções de calamidade. Segundo Sant'Anna Neto (2000), em função da intensidade da ocupação humana, quer nas atividades agrárias, quer nas aglomerações urbanas, torna-se inegável o controle das intervenções de natureza humana no meio-ambiente

A variabilidade pluviométrica e suas relativas quantidades de precipitações, com seus regimes sazonais ou diários, distribuição temporal e as intensidades de chuvas individuais (volume/duração), são algumas das características que afetam direta ou indiretamente a população, a economia e o meio natural.

A distribuição variável da pluviosidade anual apresenta um risco ao produtor agrícola, podendo retardar a expansão da área cultivada dos Cerrados, (1982), uma vez que são importantes, não somente o total das chuvas, mas também a sua distribuição durante os estágios de desenvolvimento das culturas.

O objetivo principal deste trabalho foi analisar a oscilação e a variabilidade das chuvas anuais ocorrida na porção Centro-Oeste do Estado de Mato Grosso, entre os anos de 1996 a 2001.

\section{Localização e acesso}

O Estado de Mato Grosso está localizado entre as coordenadas geográficas de latitudes $7^{\circ}$ a $18^{\circ}$ sul e longitudes $50^{\circ}$ a $62^{\circ}$ oeste de Greenwich. As altitudes variam de 100 a 1200 metros, no centro do Continente Sul Americano. 
A área delimitada para esses estudos, dentro do estado está compreendida entre, as coordenadas geográficas de latitudes $10^{\circ}$ a $14^{\circ}$ sul e longitudes $60^{\circ}$ e $55^{\circ}$ oeste de Greenwich, situando-se aproximadamente $300 \mathrm{~km}$ da cidade de Cuiabá, capital do estado (Figura 1).

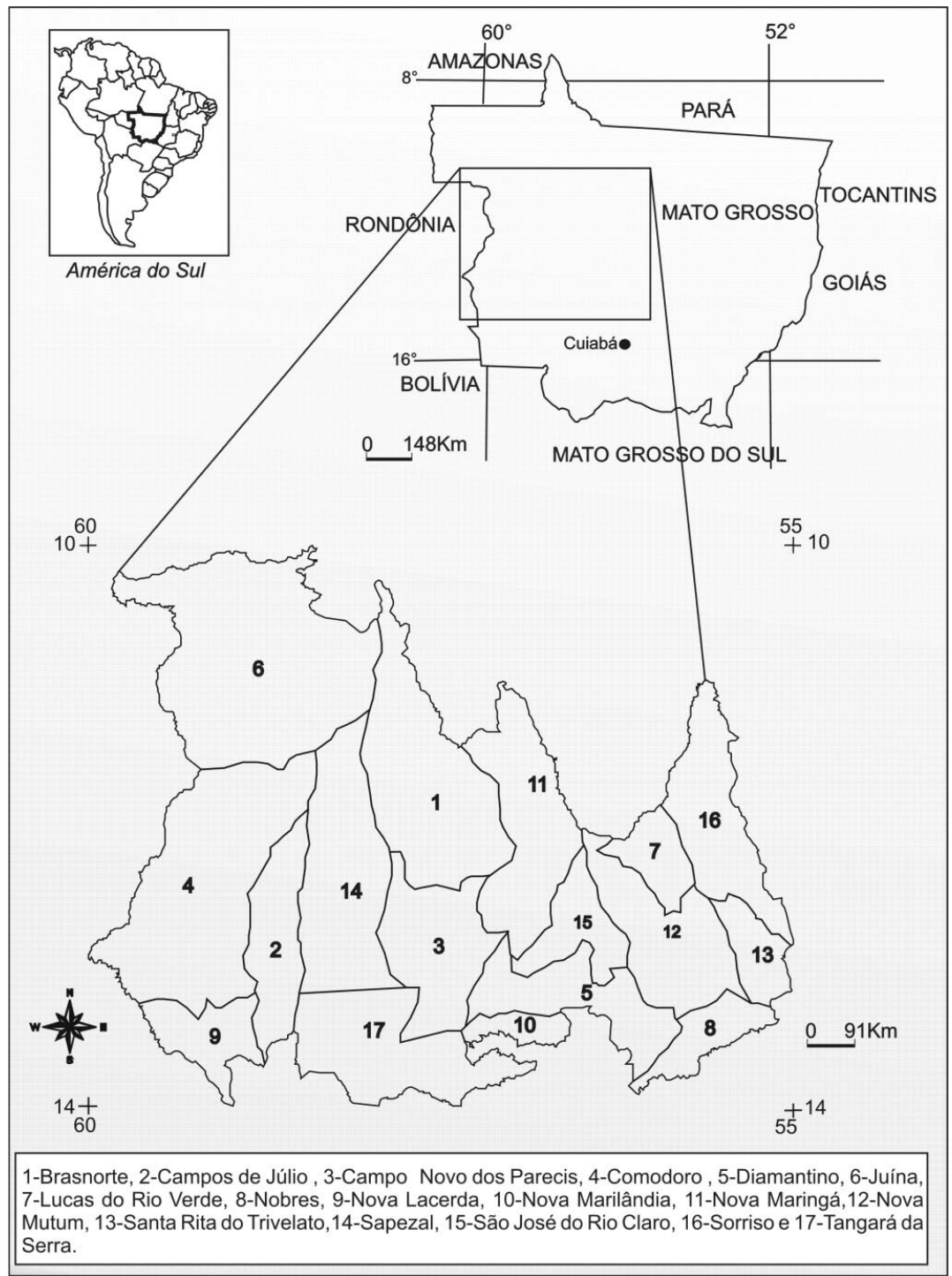

Figura 1 - Mapa de localização da área de estudos no Estado de Mato Grosso. 
O acesso à área de estudo é possibilitado através das rodovias federais BR'S - 070, 163, 174 e 364, e pelas rodovias estaduais MT'S - 160, 170, 220, 235, 319, 325, 338, 340 e 358 .

Dessa forma, constituem a área de estudo um total de 17 municípios: 1-Brasnorte, 2-Campos de Júlio, 3-Campo Novo dos Parecis, 4-Comodoro, 5-Diamantino, 6-Juína, 7-Lucas do Rio Verde, 8-Nobres, 9-Nova Lacerda, 10-Nova Marilândia, 11-Nova Maringá, 12-Nova Mutum, 13-Santa Rita do Trivelato,14-Sapezal, 15-São José do Rio Claro, 16-Sorriso e 17-Tangará da Serra, numerados em ordem alfabética.

\section{Material e métodos}

Os trabalhos metodológicos foram propostos por Matheron (1965), apud Assad et al. (1994), com a realização procedimentos teóricos e práticos, baseando-se nos dados cedidos pela Agência Nacional de Águas (ANA), e do $9^{\circ}$ Distrito de Meteorologia de Mato Grosso e Rondônia - Instituto Nacional de Meteorologia - DISME/INMET, com sede em Várzea Grande, MT, somando-se assim 14 postos pluviométricos.

Os dados analisados provêm de postos coletores fixados na área de estudo, e de estações convencionais e automáticas, onde os mesmos foram organizados primeiramente, sob a forma de arquivos ASCII, de onde foram extraídos os totais anuais, e transportados para planilha eletrônica, para a realização do recobrimento de falha, pelo método de ponderação regional, usando-se a seguinte equação: ; onde:

- yc é a precipitação do Posto Y a ser estimada; - x1, x2 e x3= as precipitações correspondentes ao ano que se desejou preencher, a falha observada em três postos de coletas vizinhos;

- ym a precipitação média do posto Y; - xm1, xm2, xm3= as precipitações médias nos três postos de coletas circunvizinhos.

Após o preenchimento de falhas, quando necessário, realizou-se a regressão linear múltipla, para se verificar e ter consistência dos dados utilizando-se a equação: yc x2i + x n1 + na; onde:

- $\mathrm{n}=$ o número de postos considerados, ao, a1, $\cdots$;

- na $=$ os coeficientes a serem estimados e 
Xli, $\mathrm{x} 2 \mathrm{i}, \cdots, \mathrm{xni}=$ as observações correspondentes registradas nos postos vizinhos.

Posteriormente, os valores foram organizados de acordo com as coordenadas geográficas, ou seja:

- a Longitude X representa a distância leste de uma marca de nível medida dentro de $[\mathrm{m}]$;

- a Latitude Y, representa o norte da distância de uma marca de nível medida também dentro de $[\mathrm{m}] \mathrm{e}$

$\mathrm{Z}$ representa a intensidade da precipitação medida dentro de [cm/hr], que corresponde aos valores dos dados hidroclimáticos a serem interpolados, tendo como resultado final a geração de mapas de isoietas no programa de Surfer versão 8, da Golden Software Inc.

Seguindo as orientações de Sousa et al. (2006), também foi definido o intervalo médio de $150 \mathrm{~mm}$, entre um valor e outro de quantidades em milímetros de chuva, o que possibilitou uma melhor padronização e interpretação dos mapas.

A área de estudos está representada por três unidades geomorfológicas, conhecidas como: Depressão Interplanáltica da Amazônia Meridional, Planalto Residual do Norte do Mato Grosso e Planalto dos Parecís (1980).

A Depressão Interplanáltica da Amazônia Meridional se descortina através de um corredor constituído por rochas pertencentes às unidades litodêmicas Complexo Xingu (et al. 1974, 1980) e Granitóide Paranaíta (Bittencourt Rosa et al. 1997), apresentando-se em longo processo de exposição e arrasamento, esculpindo relevos via de regra, planos com elevações esparsas, onde as cotas variam, entre 150 a 180 metros.

A Depressão Sul Amazônica está contida nos "limites" de atuação dos sistemas equatoriais, onde a oferta pluvial em um ano, é de 2000 a $2400 \mathrm{~mm}$ (2002).

O Planalto Residual do Norte do Mato Grosso corresponde à unidade geomorfológica representada pelas Serras do Cachimbo e Caiabís. As altitudes variam entre 400 a 520 metros, e se configuram em interflúvios que formam os modelados dos relevos residuais embutidos na Depressão Interplanáltica da Amazônia Meridional.

O Planalto dos Parecis, primeiramente estudado por Derby (1895), está compartimentado: pelo Planalto Dissecado dos Parecis e pela Chapada dos Parecis. O Planalto Dissecado dos Parecia corresponde à unidade geomorfológica que abrange uma expressiva área de planaltos distribuída através 
de terrenos paleozóicos e cenozóicos, constituindo o divisor de águas entre, as Bacias Platina e Amazônica, cujo relevo se apresenta segundo, Werle \& Alves da Silva (1996), dissecado com formas tabulares de grande amplitude, elevações residuais com cimos planos, bordejadas por escarpas que constituem patamares estruturais escalonados. A pluviometria anual é de 1000 a $2000 \mathrm{~mm}$.

A Chapada dos Parecis abrange, uma expressiva área aplainada, com altitudes que atingem os 550 metros, recoberta por um depósito de Cobertura Detrito-Laterítica de idade Tércio-Quaternária. A variação pluviométrica é de 1400 a $2000 \mathrm{~mm}$ ao ano.

O Planalto dos Parecis é o grande divisor de águas entre a Bacia Amazônica ao Norte e a Bacia Platina ao Sul. Esta vasta área, posicionada entre a zona intertropical (Floresta amazônica), savanas tropicais (Cerrado) e a Depressão Continental do Chaco (Pantanal) ao Sul, sob o ponto de vista do quadro natural, possui características marcantes. Desta forma, o Estado de Mato Grosso encontra-se numa área de transição entre a atuação dos fluxos Tropical, Equatorial e Extratropical, os quais produzem variações em tipos de tempo bem característicos desta região.

A cobertura vegetal de floresta ainda é presente, principalmente, nos setores ao norte das bacias hidrográficas dos rios Juruena e Teles Pires, destacando-se a Floresta Semidecidual Dossel Emergente, que corresponde, segundo Amaral et al. (1982) e Bittencourt Rosa et al. (2002), a uma única formação vegetal que corresponde à floresta aluvial com dossel emergente, encontrada nas planícies e terraços aluviais, notadamente em terrenos terciários e quaternários recobertos por Neossolos Quartzarênicos Hidromórficos (EMBRAPA, 1999), às vezes inundáveis.

\section{Resultados e discussão}

A interpretação e análise dos sistemas atmosféricos na América do Sul é apresentada por Monteiro (1964, 1969), citado por Sette (2002), modificado, a partir de estudos de estudos de Serra \& Rattsbonna (1942). Neste esquema, os principais sistemas atmosféricos que atuam na região central do Brasil são: Massa Tropical Continental (MTc); Massa Equatorial Continental (MEc); Massa Tropical Atlântica (MTa); Massa Equatorial Atlântica (MEa); Massa Equatorial do Atlântico Norte (MEn); Massa Polar Atlântica (MPa); Frente Polar Atlântica (FPA) e Zona de Convergência Intertropical (ZCIT). 
O pioneiro em realizar uma caracterização da circulação de superfície para o antigo Estado do Mato Grosso (MT e MS) foi Serra (1948), que descreveu o ritmo sazonal dos movimentos da baixa atmosfera para as quatro estações do ano. Posteriormente, Nimer (1979), com base nos trabalhos de Serra (1948), realizou um estudo, no qual ressalta dois fatores geográficos, ou seja, o relevo e a latitude como responsáveis da diversificação térmica. Por outro lado, estes estudiosos colocam o mecanismo atmosférico determinante na “marcha estacional de precipitação pluviométrica”, que é máxima no verão e mínima no inverno, adequando uma uniformidade regional.

De acordo com a classificação climática, para as grandes linhas do clima de Durand Dastès (1968), modificada por Estienne \& Godard (1970), as temperaturas, localmente, podem variar, entre $24^{\circ}$ a $36^{\circ} \mathrm{C}$, durante a estação chuvosa, cuja pluviometria média regional é de $1.700 \mathrm{~mm}$. A umidade relativa do ar é variável e durante a estação das chuvas pode atingir a faixa dos $80 \%$, enquanto que na estação seca ela é de aproximadamente $50 \%$.

O sistema de circulação atmosférica na região Centro-Oeste é constituído por ventos que sopram a Oeste (IT) - Linha de Instabilidades Tropicais, Norte (CIT7) - Convergência Inter-tropical e Sul (FP) - Anticiclone Polar e Frente Polar. Desta forma no entender de Nimer (1979), a pluviosidade em Mato Grosso se deve, exclusivamente, ao regime de circulação atmosférica

De acordo com classificação climática elaborada por Sette \& Tarifa (2000), os sistemas atmosféricos que atuam em Mato Grosso são: Zona de Convergência Intertropical (ZCIT), Sistema Equatorial, Sistema Tropical Continental (STC), Sistema Tropical Atlântico (STA), Sistema Polar Atlântico (SPA). Zona de Convergência do Atlântico Sul (ZCAS). Desta forma, os sistemas atmosféricos atuantes na área de estudo são: Sistema Amazônico - SAM, Tropical Continental com Subsidência - TCS, Tropical Continental Convectivo - TCC, Sistema Polar Continentalizado - SPC, Sistema Tropical Atlântico Continentalizado - TAC e Zona de Convergência do Atlântico Sul - ZCAS.

A média anual da precipitação de um núcleo mais chuvoso ao Norte de Mato Grosso pode atingir valores superiores a $2750 \mathrm{~mm}$ (Nimer, 1979).

Tais valores decrescem nas direções leste, oeste e sul do estado, resultando então, numa precipitação, que se distribui de forma irregular, durante todo o ano, sendo o verão o seu máximo e, o inverno o seu mínimo, sendo que $70 \%$ do total de chuvas acumuladas, durante o ano se precipitam entre novembro a março meses, correspondentes ao verão. Durante esse trimestre, a precipitação chega atingir 45\% até 55\% do total anual das chuvas (1989). 
Do ponto de vista agro-climatológico, a região dos cerrados está sujeita ao regime de secas, dentro da estação chuvosa, a qual pode persistir de duas a, três semanas e atingir até um mês ou mais sem chuvas, fenômeno é denominado de veranico. (et al. 1994). O fenômeno veranico é considerado por Casarim (1983) como uma causa dos bloqueios de grande escala no escoamento atmosférico. a partir desse ponto de vista, o mecanismo do veranico pode estar associado aos deslocamentos da zona de convergência tropical e ao fenômeno "El Nino", diretamente relacionado com o aumento da temperatura do Oceano Pacífico.

Em contrapartida, o inverno é extremamente seco, e é nessa época que ás chuvas são raras, com precipitações de quatro a cinco dias nos meses de junho, julho e agosto, concentrando totais muito baixos, entre 20 e 80 mm de pluviosidade, fazendo com que a região fique na dependência quase exclusiva das chuvas frontais, que são proporcionadas pela passagem de frentes polares trazidas do sul pelo anticiclone polar (FK). Desta maneira, as ocorrências de chuvas no extremo norte do Estado de Mato Grosso são conseqüências do sistema de circulação perturbada de oeste (IT) (Tarifa et al. 2006).

O trimestre de setembro a novembro é caracterizado por temperaturas extremamente aquecidas no equinócio de primavera (Outubro-Novembro), com pouca ocorrência de precipitações e o aumento gradativo do regime pluviométrico só vai acontecer com o final da primavera, coincidindo com o início do verão no mês de dezembro (et al. 1994).

O Vale do Araguaia é o que apresenta os menores totais pluviométricos com (10 a $20 \mathrm{~mm})$.

Dessa forma, segundo (Tarifa et al. 2006), as áreas de maior pluviosidade correspondem ao extremo norte e noroeste do estado e, nestas áreas os totais médios anuais variam entre 2100 a $2500 \mathrm{~mm}$.

Diante da série estudada nesses seis (06) anos, notou-se que a pluviometria comportou-se de forma bem variável. Apenas nos ano de 1998 e 1996, a soma da chuva acumulada foi a 2300 a $2350 \mathrm{~mm}$, sendo que nos demais anos, a soma total ficou sempre abaixo da média estipulada por Tarifa et al. (2006).

As intensidades pluviométricas registradas no ano de 1996, Figura 2, de maior representatividade na porção oeste ocorreram nos municípios de Comodoro, Campos de Júlio, Sapezal e Tangará da Serra com 2300 mm. Em direção ao norte e ao sul, o segundo maior valor anual foi de $2150 \mathrm{~mm}$, que ocorreu nos municípios de Juína, Brasnorte, Nova Lacerda, Nova Marilândia e Campo Novo dos Parecis. 
Dessa forma, na porção Leste, os menores valores pluviométricos foram quantificados de 1850 a $1400 \mathrm{~mm}$, que estiveram presentes nos municípios de Nova Maringá, São José do Rio Claro, Diamantino, Lucas do Rio Verde, Nova Mutum, Norbres, Sorriso e Santa Rita do Trivelato.

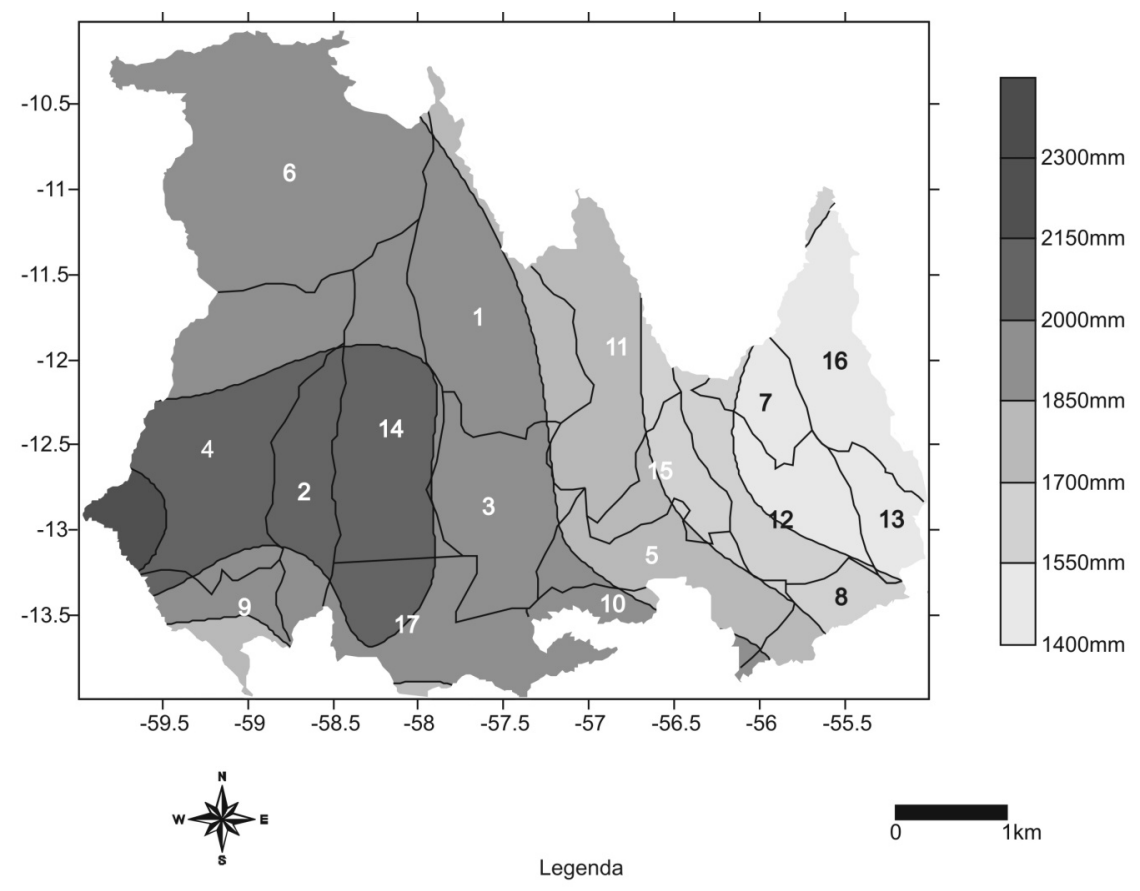

1-Brasnorte, 2-Campos de Júlio , 3-Campo Novo dos Parecis, 4-Comodoro , 5-Diamantino, 6-Juína, 7 Lucas do Rio Verde, 8-Nobres, 9-Nova Lacerda, 10-Nova Marilândia, 11-Nova Maringá,12-Nova Mutum, 13-Santa Rita do Trivelato,14-Sapezal, 15-São José do Rio Claro, 16-Sorriso e 17-Tangará da Serra.

Figura 2 - Mapa pluviométrico de 1996.

Os menores valores pluviométricos identificados no ano de 1997, Figura 3, com 1520mm, foram somados nos municípios de Nobres, Nova Mutum, Santa Rita do Trivelato e Sorriso, sendo que estes estão situados na porção Leste da área de estudo. Mediante a isso o segundo menor valor de $1670 \mathrm{~mm}$, foi observados nas porções Norte e Oeste, sendo que a espacialização está sobre os municípios de Juína, Comodoro, Nova Lacerda, Nova Maringá, Diamantino, Nova Marilândia, São José do Rio Claro e Lucas do Rio Verde.

Ainda averiguando a Figura 3, nota-se, perfeitamente que a variabilidade das chuvas aconteceu de forma bem expressiva, sendo que o núcleo 
mais chuvoso, com a maior quantidade, ocorreu no município de Tangará da Serra com 1970 mm. Nos municípios de Campos de Júlio, Sapezal e Campo Novo dos Parecis, a chuva ocorreu em menor quantidade, com $1820 \mathrm{~mm}$, sendo que estes municípios encontram-se na porção sul da área de estudo. Com isso, é importante ressaltarmos que houve um destaque chuvoso da ordem de 1820 mm na Figura 3, localizado no extremo sudoeste da área de estudo abrangendo parte dos municípios de Comodoro e Nova Lacerda.

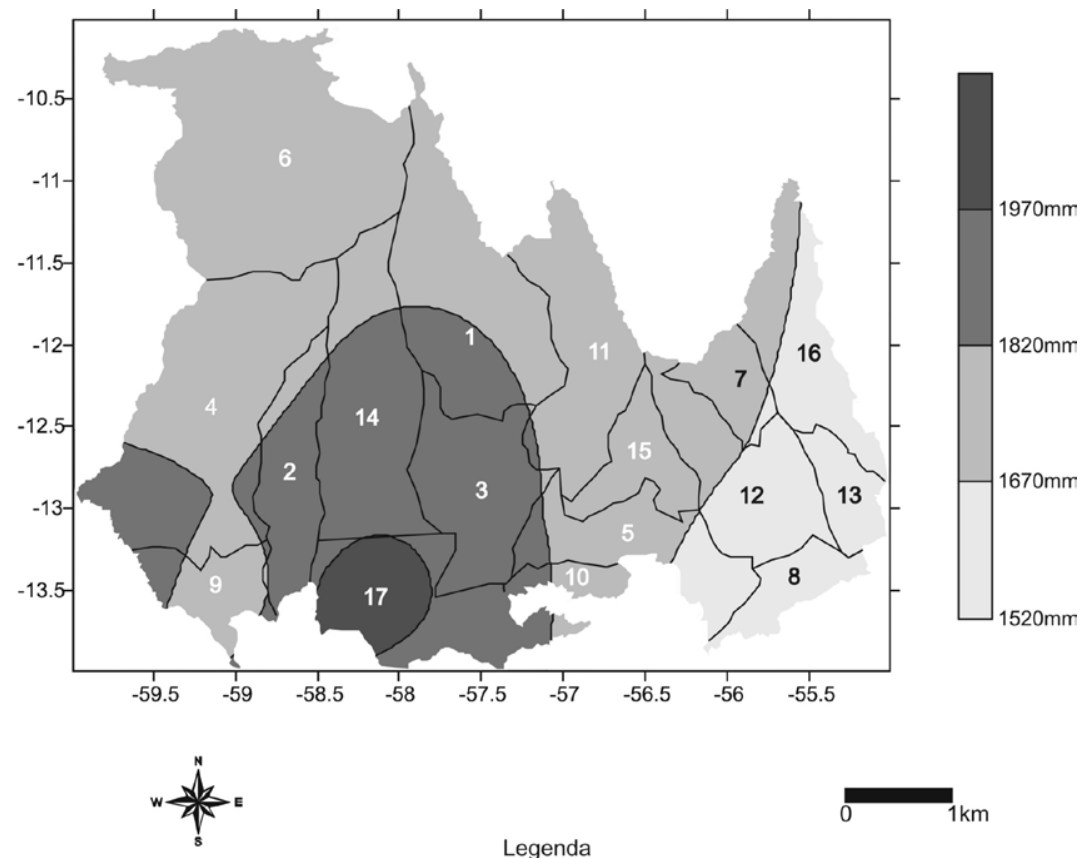

1-Brasnorte, 2-Campos de Júlio , 3-Campo Novo dos Parecis, 4-Comodoro , 5-Diamantino, 6-Juína, 7Lucas do Rio Verde, 8-Nobres, 9-Nova Lacerda, 10-Nova Marilândia, 11-Nova Maringá,12-Nova Mutum, 13-Santa Rita do Trivelato,14-Sapezal, 15-São José do Rio Claro, 16-Sorriso e 17-Tangará da Serra.

Figura 3 - Mapa pluviométrico de 1997.

A oscilação pluviométrica observada na Figura 4, referente ao ano de 1998, foi somada com a maior quantidade na porção oeste sobre os municípios de Comodoro, Nova Lacerda e Campos de Júlio com registros de 2050 até $2350 \mathrm{~mm}$. Enquanto isso, nas porções norte e na leste, a variação das chuvas foi de 1450 a1900 mm. A espacialização nos municípios de Juína, Brasnorte, Sapezal, Tangará da Serra, Campo Novo dos Parecis, Nova 
Maringá, São José do Rio Claro, Diamantino, Nova Marilândia, Lucas do Rio Verde, e no extremo norte do município de Sorriso, demonstra a atuação pluviométrica na área de estudo.

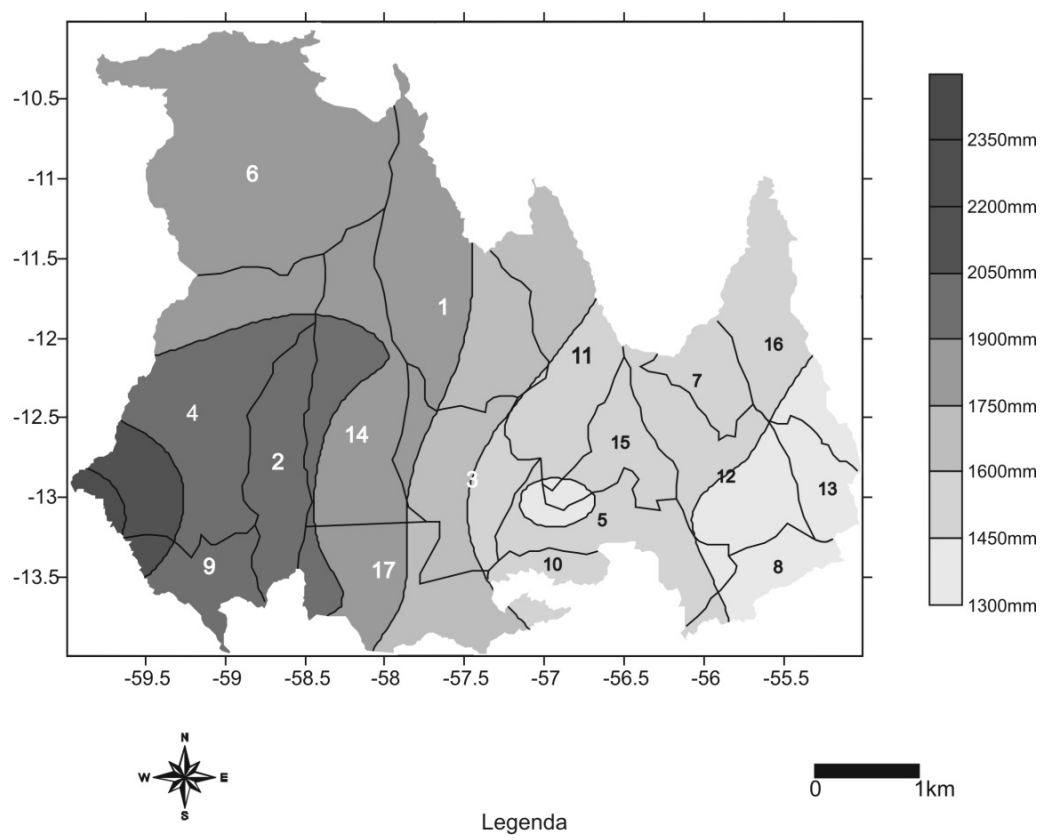

1-Brasnorte, 2-Campos de Júlio , 3-Campo Novo dos Parecis, 4-Comodoro , 5-Diamantino, 6-Juína, 7 Lucas do Rio Verde, 8-Nobres, 9-Nova Lacerda, 10-Nova Marilândia, 11-Nova Maringá,12-Nova Mutum, 13-Santa Rita do Trivelato,14-Sapezal, 15-São José do Rio Claro, 16-Sorriso e 17-Tangará da Serra.

Figura 4 - Mtapa pluviométrico de 1998.

Neste contexto, diante do exposto sobre a Figura 4, evidenciou-se que no extremo sul do município de Sorriso e nos municípios de Nova Mutum, Nobres e Santa do Trivelato, houve o menor registro pluviométrico durante todo o ano de 1998, com uma soma de 1300mm.

No ano de 1999, a variação das chuvas também ocorreu de forma bem expressiva. Novamente o maior valor pluviométrico aconteceu na porção oeste e mais precisamente, no município de Comodoro, com $1900 \mathrm{~mm}$. Já em direção à porção norte, com $1600 \mathrm{~mm}$, a chuva atuou em quantidade inferior.sobre os municípios de Juína, Campos de Júlio, Nova Lacerda, Sapezal e Brasnorte. 
Desta forma, na porção sul da área de estudos, se estendeu uma faixa chuvosa até as porções norte e leste com registro pluviométrico de $1450 \mathrm{~mm}$, abrangendo os municípios de Campo Novo dos Parecis, Tangará da Serra e o extremo sul dos municípios de Nova Marilândia, Daiamantino, e Nobres.

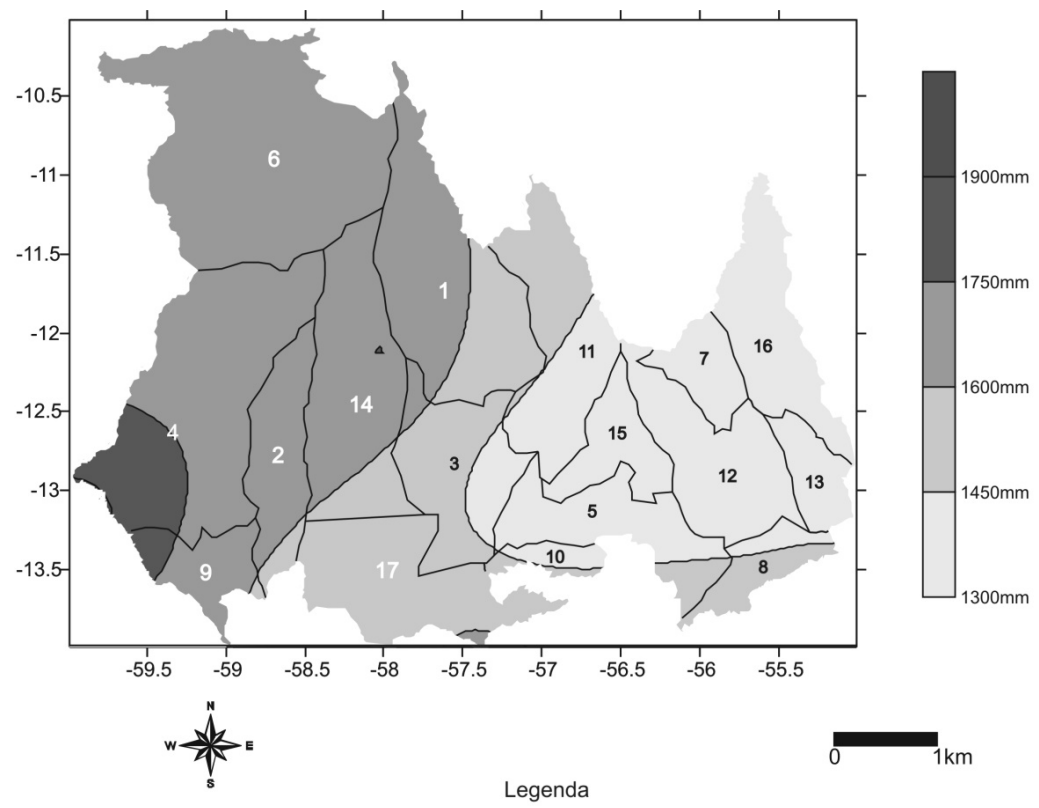

1-Brasnorte, 2-Campos de Júlio , 3-Campo Novo dos Parecis, 4-Comodoro , 5-Diamantino, 6-Juína, 7 Lucas do Rio Verde, 8-Nobres, 9-Nova Lacerda, 10-Nova Marilândia, 11-Nova Maringá,12-Nova Mutum, 13-Santa Rita do Trivelato,14-Sapezal, 15-São José do Rio Claro, 16-Sorriso e 17-Tangará da Serra.

Figura 5 - Mapa pluviométrico de 1999.

Em toda a porção leste da área de estudos representada na Figura 5, foi averiguado o menor acúmulo pluviométrico no ano de 1999, com um valor de 1300 mm nos municípios de Nova Marilândia, Nova Maringá, Diamantino, Nova Mutum, Lucas do Rio Verde, Sorriso, Santa Rita do Trivelato, e no extremo norte do município de Nobres.

O menor valor quantificado de chuva ocorrido no ano 2000 está representado na Figura 6, o qual esteve presente na porção sul, e em parte das porções norte e leste da área de estudos sobre os municípios de Brasnorte, Nova Maringá, São José do Rio Claro, Lucas do Rio Verde, Campo Novo dos Parecis, Nova Marilândia, Diamantino, Nova Mutum, Santa Rita do Trivela- 
to e Nobres. Em contrapartida, no extremo norte do município de Sorriso, a variação pluviométrica foi de $1600 \mathrm{~mm}$.

Também um valor de $1600 \mathrm{~mm}$ ocorreu em parte das porções norte e sul nos municípios de Sapezal, Campos de Júlio, Tangará da Serra e em parte do município de Juína.

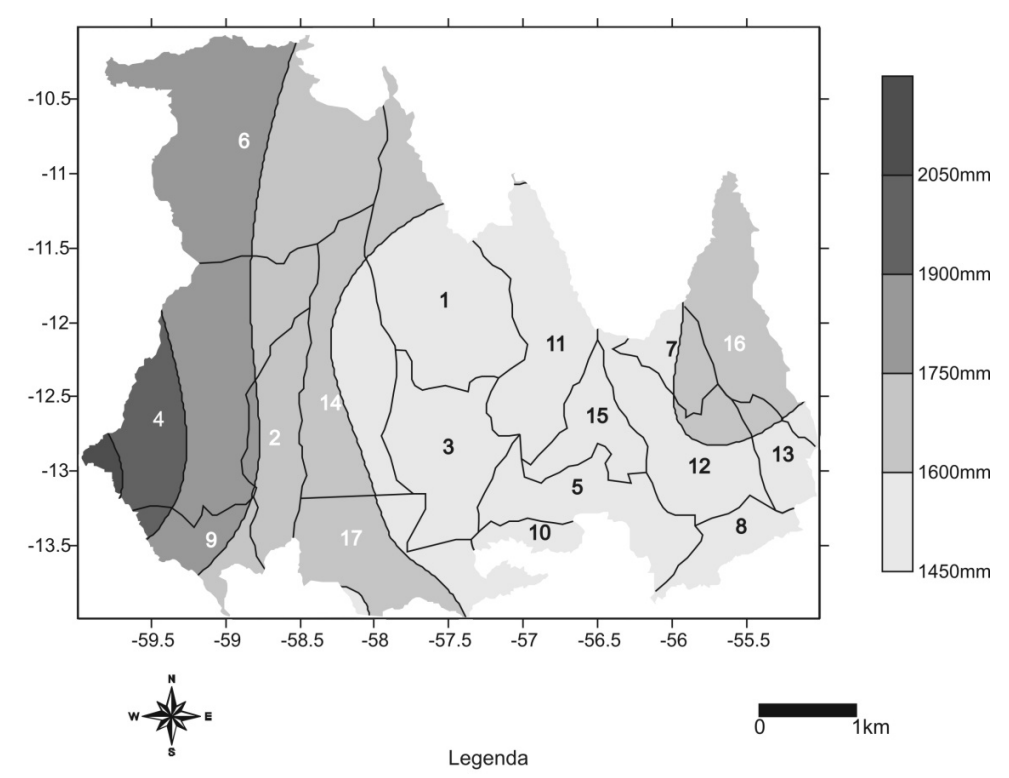

1-Brasnorte, 2-Campos de Júlio , 3-Campo Novo dos Parecis, 4-Comodoro , 5-Diamantino, 6-Juína, 7Lucas do Rio Verde, 8-Nobres, 9-Nova Lacerda, 10-Nova Marilândia, 11-Nova Maringá, 12-Nova Mutum 13-Santa Rita do Trivelato,14-Sapezal, 15-São José do Rio Claro, 16-Sorriso e 17-Tangará da Serra.

Figura 6 - Mapa pluviométrico de 2000.

Com isso, os maiores valores de 1750 até $2050 \mathrm{~mm}$ estiveram sobre os municípios de Comodoro, Nova Lacerda e no extremo oeste do município de Juína.

As intensidades pluviométricas averiguadas no ano 2001, demonstradas na Figura 7, foram em maior quantidade ocorreram no extremo oeste e norte da área de estudo com registro de $2200 \mathrm{~mm}$, no município de Comodoro, e de 1750 até 2050 mm, nos municípios de Juína, Campos de Júlio, Nova Lacerda e Sapezal.

Diante da variabilidade das chuvas ocorrida no ano de 2001, observou-se que, na porção sul, aconteceu uma faixa chuvosa em direção à porção 
norte, onde a somatória pluviométrica foi de $1600 \mathrm{~mm}$, nos municípios de Brasnorte, Campo Novo dos Parecis, Nova Maringá, Diamantino e Nova Marilândia. Na porção leste da área de estudo, nos respectivos municípios de São José do Rio Claro, Juína, Nova Mutum, Nobres, Santa Rita do Trivelato, e Sorriso, ocorreu a menor soma registrada com $1450 \mathrm{~mm}$.

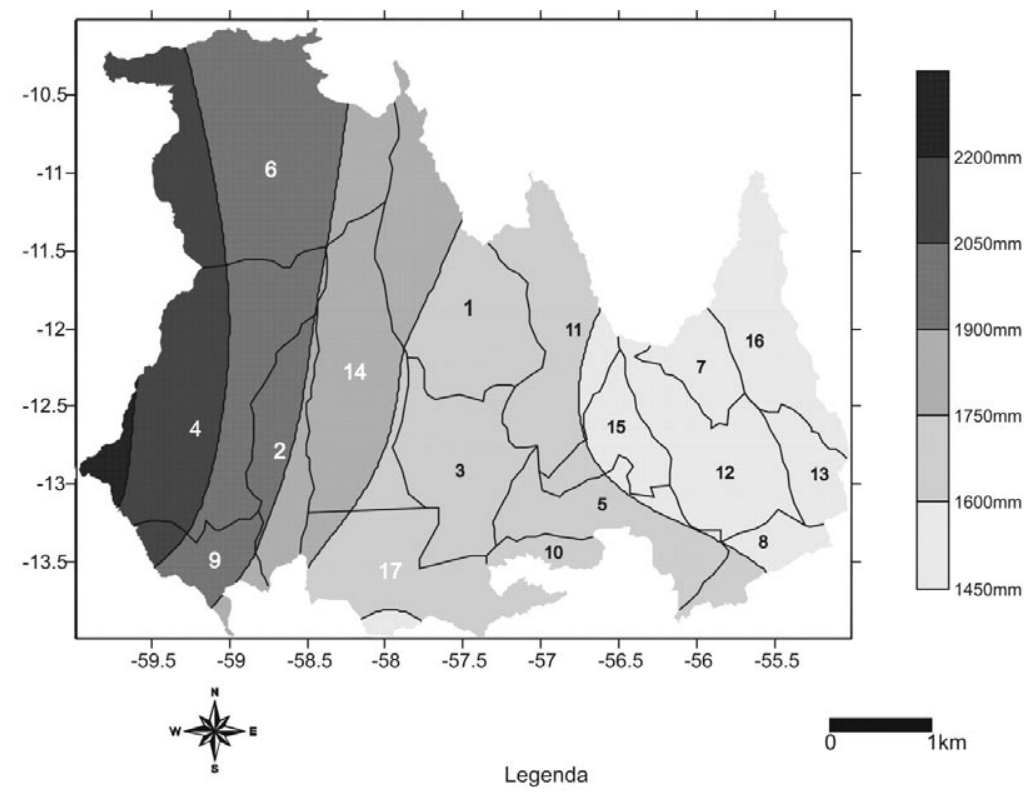

1-Brasnorte, 2-Campos de Júlio ,3-Campo Novo dos Parecis, 4-Comodoro , 5-Diamantino, 6-Juina, 7 Lucas do Rio Verde, 8-Nobres, 9-Nova Lacerda, 10-Nova Marilândia, 11-Nova Maringá,12-Nova Mutum, 13-Santa Rita do Trivelato,14-Sapezal, 15-São José do Rio Claro, 16-Sorriso e 17-Tangará da Serra.

Figura 7 - Mapa pluviométrico de 2001.

Segundo Assad \& Sano (1993), o clima do Planalto Central é caracterizado por uma estação seca bem característica e outra bem chuvosa. Este fator pode ser, de uma maneira geral, generalizado para toda a Região do Centro-Oeste do Brasil, apresentando assim uma irregularidade pluviométrica, o que acarreta a variabilidade pluviométrica, espacial e/ou temporal, tal acontecimento pode ocasionar efeitos danosos a solos desprotegidos de cobertura vegetal.

Portanto, com relação ao grande domínio morfoclimático e fitogeográfico dos cerrados, espera-se que nós, homens modernos, tenhamos um pouco mais de cuidados com o meio-ambiente, e já devemos começar a pensar numa 
possível escassez hídrica, haja vista que, na atualidade, estamos vivendo uma nova face da ocupação econômica dos cerrados com as nossas atividades urbanas e agrícolas importantes, como o agronegócio (Ab’Saber, 2003).

\section{Considerações finas}

Observando-se os mapas de isoietas de 1996 a 2001, identificou-se que, preferencialmente, as chuvas ocorreram em maior quantidade nas porções oeste e norte da área de estudos. Contudo, nas porções sul e leste, foram registrados os menores valores pluviométricos, com exceção apenas para o ano de 1997, período em que foram registradas as maiores pluviometrias, nas porções sul e norte da área de estudo e nas porções leste e oeste, onde foram quantificados os menores valores.

Diante da série estudada nesses seis (06) anos, notou-se que a pluviometria comportou-se de forma bem variável, de modo que apenas nos ano de 1998 e 1996 a soma da chuva acumulada foi a 2300 a $2350 \mathrm{~mm}$, sendo que, nos demais anos, a soma total ficou sempre abaixo da média estipulada por Tarifa et al. (2006), de 2100 até $2500 \mathrm{~mm}$.

A oscilação das chuvas foi distribuída de forma bem irregular durante este período de estudos, onde em alguns municípios as precipitações pluviométricas foram acentuadas, e em outros, menos expressivas.

Os municípios que tiveram os maiores valores pluviométricos foram Brasnorte, Campos de Júlio, Campo Novo dos Parecis, Comodoro, Juína, Nova Lacerda, Sapezal, e Tangará da Serra. Consequentemente, os menores valores chuvosos estiveram quantificados sobre os municípios de Diamantino, Nova Marilândia, Nova Maringá, Nova Mutum, Santa Rita do Trivelato, São José do Rio Claro e Sorriso.

\section{Referências}

AB'SABER, A. N. Os domínios de natureza no Brasil: potencialidades paisagísticas. Editora Ateliê, São Paulo, SP, 2003.

ASSAD, E. D. \& SANO, E. E. Sistemas de Informações Geográficas: Aplicações na Agricultura, Planaltina, DF, BRASIL/EMBRAPA - Empresa Brasileira de Pesquisas Agropecuárias/Centro de Pesquisas Agropecuárias do Cerrado - CPAC, 1993. 
ASSAD, E. D.; SANO, E. E.; MASUTOMO, R.; CASTRO, L. H. \& SILVA, F. A. M. Veranicos na região dos cerrados brasileiros freqüência e probabilidade de ocorrência. In: Chuva nos Cerrados. ASSAD, E. D. (Coordenador). BRASIL/ EMBRAPA - Empresa Brasileira de Pesquisas Agropecuárias/Centro de Pesquisas Agropecuárias do Cerrado-CPAC, 423 p. Brasília, DF. 1994.

AMARAL, D. L.; FONZAR, B. C. \& OLIVEIRA FILHO, L. C. de. Vegetação. As Regiões Fitoecológicas, sua Natureza e seus Recursos Econômicos. Folha SD.21/Cuiabá. BRASIL/Ministério das Minas e Energia. Projeto RADAMBRASIL, (Levantamento dos Recursos Naturais, 26), p. 401 452, Rio de Janeiro, RJ. 1982.

AYOADE, J. O. 2004. Introdução à climatologia para os trópicos. Ed. Bertrand Brasil, 10ª edição, 332p, Rio de Janeiro, RJ.

BITTENCOURT ROSA, D.; ALVES da SILVA, M.; \& MENEZES LIMA, P. R. As Características Geológicas e Mineralógicas do Granitóide Paranaíta. In: SIMPÓSIO DE GEOLOGIA DO CENTRO OESTE, 6, Cuiabá, MT, UFMT, Anais do., p. 3 - 7, Sociedade Brasileira de Geologia, Núcleo Centro Oeste, Cuiabá, MT. 1997.

BITTENCOURT ROSA, D.; GELA, A.; ALVES, D. de. O.; MACEDO, M.; NASCIMENTO, L. A.; GARCIA NETTO, L. da. R.; PINTO, S. D. S.; BORGES, C. A.; ROSSETO, O. C.; TOCANTINS, N.; LOPES dos SANTOS, P \& GERALDO, A. C. H. Um Estudo Geoambiental Comparativo das Características Morfoestruturais e Morfoesculturais nas Áreas das Bacias do Alto Rio Paraguai e do Rio Teles Pires no Estado de Mato Grosso. Projeto de Pesquisa, Relatório Final Fundação de Amparo à Pesquisa do Estado de Mato Grosso/Conselho Nacional de Desenvolvimento Científico e Tecnológico - FAPEMAT/CNPq, 319 p, Cuiabá, MT. 2002.

CASARIM, D.P.Um estudo observacional sobre os sistemas de bloqueio no hemisfério Sul. In: Chuva nos Cerrados. ASSAD, E. D. (Coordenador), Empresa Brasileira de Pesquisas Agropecuárias - EMBRAPA/Centro de Pesquisas Agropecuárias do Cerrado - CPAC, 423p. Brasília, DF. 1983.

DERBY, O. A. Nota sobre a Geologia e a Paleontologia de Mato Grosso. Archivos do Museu Nacional, (9): 59 - 88, Rio de Janeiro, RJ. 1895.

DURAND-DASTÈS, F. 1968. Climatologie, Encyclopaedia Universalis, 4, p. 618 - 624 .

GARRIDO, W. E.; AZEVEDO. L. G. \& JÚNIOR, M. J. 1982. O clima da região dos cerrados em relação à agricultura. BRASIL/ EMBRAPA - Empresa Brasileira de Pesquisas Agropecuárias/ Centro de Pesquisas Agropecuárias do Cerrado-CPAC, 423 p. Brasília, DF.

EMBRAPA/BRASIL. Empresa Brasileira de Pesquisa Agropecuária. 1999. Sistema Brasileiro de Classificação dos Solos. 429 p, Brasília, DF.

ESTIENNE, P. \& GODARD, A. Climatologie. Armand Colin, Collection U, 365 p, Paris. 1970.

HUGO SILVA, G. H.; LEAL, J. W. L.; SALUM, O. A. L.; DALL'AGNOL, R. \& BASET, M. A. S. Esboço Geológico de Parte da Folha SC/21 - Juruena. In: CONGRESSO BRASILEIRO DE GEOLOGIA, 28, Porto Alegre, RS, Anais do., V. 4, p. 309 - 320, Soc. Bras. Geologia, Porto Alegre, RS. 1974. 
HUGO SILVA, G. H.; LEAL, J. W. L.; MONTALVÃO, R. M. G. de.; BEZERRA, P. E. L.; PIMENTA, O. N. dos.; TASSINARI, C. C. G.\& FERNANDES, C.A.C. Geologia, Folha SC/21 - Juruena. BRASIL. DNPM/MME, Projeto RADAMBRASIL, (Levantamento dos Recursos Naturais, 20), Rio de Janeiro, RJ, p. 21 - 117. 1980.

JURCA, J. \& TOMMASELLI, J. T. G. Contribuição ao zoneamento agroclimático no Estado de São Paulo por meio das classificações climáticas. In: SIMPÓSIO BRASILEIRO DE CLIMATOLOGIA GEOGRÁFICA, V, Curitiba, PR, Cd-rom. 2002.

MATHERON, G. Les variables régionalises et leur estimation. Masson, 305 p, Paris. 1965.

MELO, D. P. \& FRANCO, M. do. S. M. Geomorfologia. Folha SC/21. BRASIL. Departamento Nacional da Produção Mineral. Projeto RADAMBRASIL (Levantamento dos Recursos Naturais, 20), p. 117 - 164, Rio de Janeiro, RJ. 1980.

MONTEIRO, C. A. de F. A Frente Polar Atlântica e as Chuvas de Inverno na Fachada Sul(Oriental do Brasil contribuição metodológica à análise rítmica dos tipos de tempo no Brasil). Série Teses e Monografias, 1, IGEOG/ USP, São Paulo, SP, 69p. 1969.

NIMER, E. Climatologia do Brasil, BRASIL. IBGE, 422 p, Rio de Janeiro, RJ. 1979.

NIMER, E. \& BRANDÃO, A. M. P. M. Balanço hídrico e clima da região dos cerrados. BRASIL. IBGE, 166 p, Rio de Janeiro, RJ. 1989.

SANT'ANNA NETO, J. L. As chuvas no Estado de São Paulo: A variabilidade pluvial nos últimos 100 anos. In: Variabilidade e mudanças climáticas, implicações ambientais e socioeconômicas. SANT'ANNA NETO, J. L. \& ZAVATINI, J. A., (Orgs.) Maringá, PR: Eduem, p. 95 - 112. 2000.

SERRA, A. \& RATISBONNA, L. As massas de ar na América do Sul, Serviço de Meteorologia do Ministério da Agricultura, 59 p, Rio de Janeiro, RJ. 1942.

SERRA, A. Previsão do Tempo. In: Boletim Geográfico, IBGE, Rio de Janeiro, RJ. 1948.

SETTE. D. M. \& TARIFA, J. R. O holorítmo e a gênese dos climas no Mato Grosso- Brasil, In: SIMPÓSIO BRASILEIRO DE CLIMATOLOGIA GEOGRÁFICA, IV, Rio de Janeiro, RJ, Cd-rom. 2000.

SETTE. D. M. Os sistemas atmosféricos de superfície, a circulação secundária e os principais tipos de tempo que atuam no centro do continente sul americano - Mato Grosso - Brasil. In: SIMPÓSIO BRASILEIRO DE CLIMATOLOGIA GEOGRÁFICA, V, Curitiba, PR, Cd-rom. 2002.

SOUSA, R. R.; BITTENCOURT ROSA, D.; NASCIMENTO, L. A. \& LIMA, P. R. M. Estudo da variabilidade pluviométrica no extremo norte do estado de Mato Grosso Entre os anos de 1990 a 1996. Revista Geoambiente On-line, Ano 2006, n. 7, p. 89 - 107, Jataí, GO. 2006.

TARIFA, J. R.; SETTE, D. M.; MADRUGA, L. C. MOREIRA, M. L. C.; ORMOND, G. L.; FILHO, V. D.; SANTOS, J. F. Atlas Climatológico de Mato Grosso: Departamento de Geografia-Universidade Federal de Mato Grosso (UFMT), Cd-rom, Rondonópolis, MT. 2006. 
WERLE, H. J. S. \& ALVES da SILVA, M. Unidades do Relevo de Mato Grosso: Uma Proposta de Classificação. Revista Sociedade \& Natureza, Departamento de Geografia, Universidade Federal de Uberlândia (UFU), Ano 3, n. 15, p. 409 - 415, Uberlândia, MG. 1996.

Romário Rosa de Sousa - mestrando do Programa de pós-graduação em geografia da Universidade Federal de Mato Grosso

Luiz Gonzaga - mestrando do Programa de pós-graduação em geografia da Universidade Federal de Mato Grosso

Doroty Queiroz Topanotti - mestrando do Programa de pós-graduação em geografia da Universidade Federal de Mato Grosso 



\title{
Capacidade de uso das terras como suporte ao planejamento ambiental na bacia hidrográfica do ribeirão Santo Antônio - Iporá-Go
}

\author{
Capacity of use of lands as has supported to the ambient planning in basin hydrográfic of the brook \\ saint Antonio - Iporá-Go
}

Flávio Alves de Sousa

flaueg@hotmail.com

Cláudia Valéria de Lima

flaueg@hotmail.com

\section{Resumo}

Diante das grandes transformações que estão ocorrendo no espaço geográfico, sobretudo em ambientes rurais, onde a demanda pela produção de alimentos se faz de maneira cada vez mais intensa, o planejamento de ações exploratórias dos recursos naturais, principalmente solos e água, se torna cada vez mais necessário, na tentativa de minimizar, ou mesmo resolver problemas ambientais ligados à exploração irracional dos recursos que garantam a nossa sobrevivência. Diante disso, o presente artigo trata sobre a importância de se avaliar a capacidade de uso das terras em bacias hidrográficas para melhor planejar ações ligadas à produtividade e à preservação dos recursos naturais para esta e para as gerações futuras. Discute, ainda as etapas necessárias para a elaboração da carta de capacidade de uso da terra e apresenta um estudo de caso na bacia do Ribeirão Santo Antônio no município de Iporá, Estado de Goiás, Brasil.

Palavras-chave: planejamento, recursos naturais, bacia hidrográfica

\begin{abstract}
Ahead of the great transformations that are occurring in the geographic space, over all in agricultural environments, whose demand for the food production if gives in way each more intense time, the planning of actions that uses the natural resources, mainly ground and water, if becomes each time more necessary, in the attempt to minimize or same to decide on ambient problems to exploration irrational of the resources that guarantee our survival. Ahead to this, the present article deals with on importance if evaluating the capacity of use of lands in hydrographic basins, better to plan on actions to the productivity and the preservation of natural resources, for this, and the future generations. It still argues the steps that if must give in the elaboration of such study, and presents a study of case in the basin of the brook Saint Antonio, in the city of Iporá, State of Goiás, Brazil.
\end{abstract}

Keywords: Management, natural resurces, hydrografic basin

\begin{tabular}{|l|c|c|c|c|c|c|}
\hline Boletim Goiano de Geografia & Goiânia - Goiás - Brasil & v. 27 & n. 3 & p. 91-101 & jul. / dez. & 2007 \\
\hline
\end{tabular}





\section{Introducão}

A bacia hidrográfica do Ribeirão Santo Atônio se localiza entre os paralelos $16^{\circ} 19^{\prime} 45^{\prime \prime}$ e $16^{\circ} 42^{\prime} 05^{\prime \prime}$ Sul, e os meridianos $51^{\circ} 04^{\prime} 30^{\prime \prime}$ e $51^{\circ} 23^{\prime} 27^{\prime \prime}$ Oeste. Abrange três municípios da região Oeste do Estado de Goiás (Iporá, Amorinópolis e Ivolândia) e apresenta uma área total de $650 \mathrm{Km} 2$, sendo que cerca de $75 \%$ (setenta e cinco por cento) desta área se encontra no município de Iporá. A área da bacia está representada nas Folhas Topográficas SE-22-V-B-III (Iporá) e SE-22-V-B-IV (Amorinópolis), ambas editadas pelo IBGE (Figura 1).

O presente artigo é parte dos resultados de um estudo sobre o uso e ocupação na bacia hidrográfica do Ribeirão Santo Antônio no município de Iporá, Estado de Goiás, que teve por objetivo principal avaliar as características físicas e a sua ocupação atual, bem como avaliar o grau de conservação de seus principais recursos naturais. Este trabalho é, então, uma tentativa de gerar maiores informações sobre a forma de exploração racional do meio físico na bacia hidrográfica do Ribeirão Santo Antônio, uma vez que a mesma representa a fonte de abastecimento de água para o município de Iporá, e que sabemos estar bastante comprometida com a má utilização das terras e a retirada maciça da cobertura vegetal nativa.

\section{Aspectos físicos da bacia}

A área apresenta uma paisagem bastante complexa, com variações litológicas que alteram as feições dos solos, da vegetação e do relevo, bem como da própria rede de drenagem. Entretanto, a sua diversificação fisionômica e morfológica interfere diretamente no uso e ocupação das terras, que, por isso, mesmo requerem uma maior atenção.

\section{Geologia}

A geologia local compreende uma grande variedade de rochas de idades variadas, que vão do Pré-cambriano até coberturas quaternárias. Neste contexto, destacam-se terrenos do Complexo granítico-gnaissico representados principalmente por rochas graníticas, que ocupam a área central da bacia. 
A Seqüência Meta-Vulcano-Sedimentar Iporá-Amorinópolis (Neoproterozóico) engloba rochas metavulcânicas básicas e ácidas associadas com metassedimentos (Moreton, 1999), ocorrem na porção sul da bacia, nas proximidades da cidade de Amorinópolis, e se estendem na direção norte em uma faixa estreita da bacia.

Os granitos Tipo Iporá (Neoproterozóico) exibem corpos de amplas variedades petrográficas e ocupam quase a totalidade da porção norte da bacia, às vezes, em contato com litologias sedimentares e vulcânicas básicas.

O Grupo Paraná (Paleozóico - Devoniano) está representado pelas Formações Furnas e Ponta Grossa. A Formação Furnas ocorre em porções variadas na área de estudo, intercalada com litologias diversas. Rochas da Formação Ponta Grossa aparecem disseminadas em todos os quadrantes da bacia, ora em afloramentos contínuos (oeste da bacia), ora intercalados a litologias de constituição e idades diversas.

O Grupo Iporá (Mesozóico - Cretáceo) caracteriza-se por ocorrências de rochas vulcânicas e intrusivas de natureza alcalina e, na área de estudo, afloram principalmente na porção N-NE em pequenas manchas, estando, quase sempre, em contato com as Formações Furnas e Ponta Grossa.

As Coberturas Detrítico-Lateríticas (Cenozóico) ocorrem de forma dispersa em alguns pontos da bacia, tendo maior área de exposição nos domínios dos terrenos granítico-gnáissicos e vulcano-sedimentares.

\section{Geomorfologia}

A geomorfologia na bacia do Ribeirão Santo Antônio apresenta três unidades geomorfológicas regionais, unidades estas definidas pelos estudos geomorfológicos do Projeto Radambrasil, representados na Folha SE.22 (Goiânia), quais sejam: Planalto Central Goiano, representado pelo Planalto do Alto Tocantins-Araguaia; Planaltos e Chapadas da Bacia Sedimentar do Paraná, representado pelo Planalto Setentrional da Bacia do Paraná e Depressão do Araguaia.

A partir da análise do mapa hipsométrico que foi elaborado com a finalidade de auxiliar na compreensão da geomorfologia local, foi possível verificar que a área apresenta altitudes que variam de 400 a 750 m, e que as menores cotas de altitude se encontram na parte central da bacia, coincidindo com o maior grau de entalhamento do relevo, determinado pela drenagem do Ribeirão Santo Antônio. 
Com o auxílio de imagem de satélite Landsat 7 TM, foi possível reconhecer as principais feições de relevo presentes na bacia, onde predominam relevos de topos aguçados, convexos, planos ou tabulares.

Finalmente, foi construído o mapa geomorfológico da área, na qual foram representadas as grandes unidades geomorfológicas regionais derivadas do mapeamento do Projeto Radambrasil Folha SE.22 (Goiânia) e também os compartimentos geomorfológicos locais. Estes compartimentos foram definidos como:

a) Superfície Denudacional Elevada, que representa as áreas de cimeira da bacia, onde predominam os maiores índices de erosão;

b) Superfície Denudacional Intermediária, que atua como área de fornecimento e recebimento de sedimentos;

c) Superfície Denudacional/Agradacional, sendo a que mais recebe sedimentos das áreas mais elevadas, porém promove a retirada de sedimentos através de atuação maior da erosão laminar.

\section{Solos}

A diversificação do relevo favorece uma grande variedade de solos, ocorrendo desde solos bem desenvolvidos, como os Latossolos e os Argissolos, a solos menos desenvolvidos, como Neossolos Litólicos distróficos e eutróficos.

Encontram-se ainda presentes na área solos do tipo Cambissolo distrófico e eutrófico com texturas pedregosa e média cascalhenta em relevo ondulado e forte ondulado.

\section{Cobertura Vegetal}

Com relação ao domínio vegetacional, a área encontra-se situada no domínio fitogeográfico denominado Savana/cerrado por Magnago et al (1983). Na área de estudo, predomina uma paisagem fitogeográfica bastante alterada pela inserção de pastagens artificiais. As áreas de vegetação nativa remanescentes, embora alteradas, estão ao longo de alguns cursos d'água (matas ciliares) e nos interflúvios, associadas a solos pouco desenvolvidos com alguns resquícios de Floresta Estacional preservadas em médias vertentes e em solos mais desenvolvidos. 


\section{Clima}

A área de estudo está inserida no clima tropical subúmido do tipo Aw (Köppen, 1948), com um período seco (abril a setembro) e outro chuvoso (outubro a março),

De acordo com dados do Sistema Meteorológico de Goiás (SIMEGO), nos municípios que formam a bacia, a precipitação média varia de $(1400$ $1600 \mathrm{~mm} / \mathrm{ano}$ ). Os meses de junho a agosto são os mais secos e os meses de fevereiro, março, novembro e dezembro, os mais chuvosos. A temperatura média é de cerca de $25,24^{\circ} \mathrm{C}$, a maior temperatura é atingida geralmente nos meses de agosto a setembro, e as menores, entre junho e julho.

\section{Capacidade de uso das terras na bacia do ribeirão Santo Antônio}

O estudo da capacidade de uso das terras tem por finalidade o planejamento de ações que venham ao encontro do potencial ecológico, econômico e produtivo dos solos, levando, a cada local, técnicas de cultivo e de manejo adequados à sua aptidão. Dentre os maiores problemas relacionados ao uso das terras destaca-se, o risco de erosão, fato comum nas terras cultivadas sem planejamento, onde, muitas vezes, a recuperação se torna inviável ou até impossível.

É preciso considerar, além dos solos, o declive que associado com a falta ou precariedade da cobertura vegetal e com os índices e intensidades de chuva, pode provocar processos erosivos em maior ou menor grau.

Os solos com declive muito acentuado, por exemplo, tem capacidade de uso, no máximo, para pastagens ou reflorestamento, sendo desaconselhável o uso com culturas anuais, que necessitam revolvimento anual com arado. (LEPSCH, 2000, p. 169).

Neste estudo, foi feita uma avaliação parcial da capacidade à erosão laminar dos solos, utilizando-se a metodologia de Salomão (1995) que propõe a determinação da erodibilidade dos solos que no presente estudo, foi determinada através da identificação dos solos da bacia estudada e posteriormente, definida segundo o seu grau, com base nos estudos realizados por Bertoni e Lombardi Neto (1985) para os solos, do Estado de São Paulo. Uma vez conhecidos os índices relativos de erodibilidade de cada tipo de solo fezse o cruzamento das classes de erodibilidade com as classes de declividades encontradas para a bacia, através do mapa de declividades. 
Definidas as classes de suscetibilidade à erosão laminar foram definidas as classes de capacidade de uso das terras conforme metodologia de Lepsch (2000).

As classes de capacidade de uso das terras foram elaboradas com base no mapa de suscetibilidade à erosão laminar, no qual cada classe de suscetibilidade corresponde a uma ou mais classes de capacidade de uso da terra. Por exemplo, a classe de suscetibilidade I (Extremamente suscetível) equivale às classes de capacidade de uso VII e VIII de Lepsch (op cit), ou seja, terras com limitações permanentes mais severas, mesmo quando ocupadas com pastagens e terras nas quais não é aconselhável qualquer tipo de lavoura, pastagens ou florestas comerciais e devem ser reservadas para proteção da fauna e flora silvestre ou recreação controlada.

A seguir, tem-se a relação entre as classes de suscetibilidade à erosão laminar e sua relação com as classes de capacidade de uso das terras.

- A classe I de suscetibilidade (Extremamente suscetível), corresponde às classes VII e VIII de capacidade de uso das terras;

- A classe II de suscetibilidade (Muito Suscetível), corresponde à classe VI de capacidade de uso das terras;

- A classe III de suscetibilidade (Moderadamente Suscetível), corresponde à classe IV de capacidade de uso das terras;

- A classe IV de suscetibilidade (Pouco Suscetível), corresponde à classe III de capacidade de uso das terras;

- A classe V de suscetibilidade (Pouco a Não Suscetível), corresponde às classes I, II, e V de capacidade de uso das terras.

A utilização dos critérios de capacidade de uso das terras deve sempre vir seguida de práticas de manejo e conservação, condizentes com cada caso, além de uma preocupação séria com o cumprimento da legislação ambiental, principalmente no que diz respeito às áreas de preservação permanente.

Tendo como base o mapa de uso e ocupação atual do solo (Figura 2), foi possível estabelecer se o uso atual é ou não compatível com a suscetibilidade erosiva da área, conforme estabelece Salomão (1995).

A cobertura vegetal reflete o nível de proteção do solo em função da ação das chuvas e, consequentemente à erosão, enquanto a ação antrópica indica as áreas mais sujeitas à erosão laminar, pois o uso mais intensivo aumenta o potencial de perda de solo. Com base nisso, são estabelecidas as seguintes classes de uso e ocupação do solo: 
Classe I : cobertura vegetal de baixo e médio porte, com intensa atividade antrópica (culturas anuais, estradas e áreas urbanizadas);

Classe II: cobertura vegetal de baixo e médio porte, com atividade antrópica moderada (culturas perenes, cana-de-açúcar e pastagens);

Classe III - cobertura vegetal de baixo a médio porte, com atividade antrópica muito reduzida (pasto sujo e campo cerrado);

Classe IV - cobertura vegetal de porte alto a médio, com atividade antrópica muito reduzida (reflorestamento, capoeirão e florestas);

Classe V - espelhos d'água e várzeas, cujo potencial erosivo pode ser considerado nulo.

O mapa de suscetibilidade à erosão laminar foi construído com base na metodologia de Salomão (1995), sendo este mapa resultante do cruzamento entre solos declividade.

Cruzando a suscetibilidade à erosão laminar com as classes de ocupação atual das terras, se obtveram as classes de potencial atual à erosão laminar. Em função da generalização determinada pela escala de trabalho (1:100.000), a classe II (ocupação atual das terras) foi a que se destacou, e ao ser cruzada com as classes de suscetibilidade à erosão laminar estabelecidas para a bacia, resultou em três classes de potencial atual à erosão laminar, conforme o quadro abaixo.

Quadro 1. Classes de potencial atual à erosão laminar na Bacia do Ribeirão Santo Antônio.

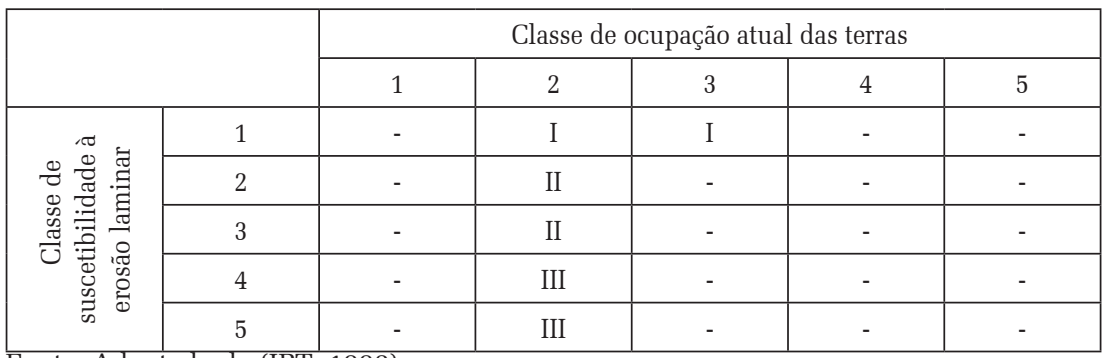

Fonte: Adaptado do (IPT, 1990).

O principal uso na bacia do Ribeirão Santo Antônio é a pastagem, que ocupa $75 \%$ do total da área. Na maior parte da bacia, a vegetação é de pequeno a médio porte em função das próprias características morfológicas do domínio do cerrado, onde se insere a bacia. 
Observando o quadro acima, temos os seguintes potenciais:

Quando cruzada a classe I de suscetibilidade à erosão laminar (extremamente suscetível), com as classes II e III de ocupação atual, obteve-se uma classe I de potencial atual, que representa um alto potencial, onde o uso atual do solo é incompatível com a suscetibilidade à erosão laminar. Estas áreas deveriam estar completamente preservadas. Em alguns pontos a vegetação nativa está de certa forma preservada, porém de forma descontínua em relação ao que deveria ser.

A classe II (Muito Suscetível) de suscetibilidade, quando cruzada com a classe II de ocupação atual, resultou numa classe II de potencial atual à erosão laminar, que apresenta médio potencial, significando um uso atual do solo incompatível com a suscetibilidade à erosão laminar, mas que pode ser controlada com práticas conservacionistas adequadas.

A classe III (Moderadamente Suscetível) de suscetibilidade, quando cruzada com a classe II de ocupação atual, resultou numa classe II de potencial atual à erosão laminar, com médio potencial, como descrito acima.

As classes de suscetibilidade à erosão laminar IV e V (Pouco Suscetível e Pouco a Não Suscetível respectivamente), quando cruzadas com a classe II de ocupação atual, resultaram na classe III de potencial atual à erosão laminar, ou seja, baixo potencial com um uso atual compatível com a suscetibilidade à erosão laminar.

Diante das análises e cruzamentos dos mapas temáticos foi possível perceber que a bacia do Ribeirão Santo Antônio apresenta sérias restrições quanto à sua ocupação e uso. As áreas com restrições em função do potencial atual à erosão laminar compreendem cerca de $70 \%$ do total de área da bacia.

Quanto ao tipo de uso recomendado, percebe-se que, de maneira geral, a bacia do Ribeirão Santo Antônio necessita de um planejamento que atenda a sua potencialidade econômica juntamente com a preservação de seus recursos naturais, principalmente água e solos.

A Figura 3 mostra a capacidade de uso das terras na bacia, enquanto o Quadro 2 mostra as porcentagens da bacia e suas aptidões de uso segundo suas características físicas.

A porcentagem da bacia ocupada por pastagens supera o limite recomendado para este tipo de uso, ou seja, pelas recomendações segundo a capacidade de uso das terras, apenas aproximadamente $50 \%$ da área total da bacia poderia estar ocupada com pastagens, que no uso atual compreende $75 \%$. 
Quadro 2. Uso recomendado segundo a capacidade de uso da terra.

\begin{tabular}{|l|c|c|}
\hline \multicolumn{1}{|c|}{ Uso Recomendado } & $\begin{array}{c}\text { Classe relativa de capacidade } \\
\text { de uso da terra }\end{array}$ & (\%) da Bacia \\
\hline Silvicultura, com restrições para pastagens. & VI & 42 \\
\hline Preservação permanente/Reflorestamento & VII e VIII & 10 \\
\hline Pastagens e culturas perenes & III & 3 \\
\hline Área com restrição parcial a qualquer cultivo & IV & 25 \\
\hline Área favorável para lavouras e pastagens & I, II, e V & 20 \\
\hline
\end{tabular}

Fonte: Adaptado de (LEPSC, 2000).

\section{Conclusões}

A irregularidade do relevo tem bastante influência sobre o uso da terra, pois, embora, na totalidade predomine, declividades mais amenas, as mesmas não são contínuas, nem mesmo a sua extensão é suficiente para um plantio de culturas temporárias, principalmente as de exportação, sendo estas, cultivadas esporadicamente e em pequena proporção dentro da bacia.

$\mathrm{O}$ uso da terra por pastagem se deve, principalmente, à irregularidade do relevo e a pouca extensão de solos bem desenvolvidos.

A declividade na bacia do Ribeirão Santo Antônio é bastante variada, porém predominam declividades entre 0 e 3\% com cerca de 56\% da área total da bacia, mas, esta classe de declividade não favorece o plantio de culturas temporárias que ocupem grandes extensões de terra, devido à descontinuidade ao longo da bacia. Embora as declividades mais acentuadas (acima de 20\%), ocupem apenas 7\% da área total da bacia, o relevo é bastante irregular, o que favorece uma variedade de tipos de solos.

As chuvas na região da bacia são concentradas em alguns meses específicos e, na totalidade, apresentam índices anuais bastante variáveis.

Outra observação importante refere-se à inexpressiva presença de vegetação nativa na bacia. As matas ciliares são descontínuas, não obedecem às faixas de largura estabelecidas pelo Código Florestal Brasileiro, sem contar a ausência de áreas destinadas à reserva legal, que não atinge os $20 \%$ recomendados.

A má conservação da vegetação nativa e dos solos favorece a erosão laminar, sendo que cerca de $52 \%$ da bacia apresenta suscetibilidade erosiva que vai de muito forte a extremamente forte, carecendo um melhor manejo para a área. 
A erosão linear aparece, predominantemente, na forma de sulcos e ravinas favorecidos pela má conservação dos solos e pela ausência de cobertura vegetal nativa.

De maneira geral, a bacia apresenta uma boa potencialidade ao uso econômico, porém é preciso que o seu uso seja bem planejado, seguindo os critérios de capacidade de uso das terras e utilizando os devidos procedimentos de manejo.

\section{Referências}

BERTONI, J. \& LOMBARDI NETO, F. - Conservação do Solo. Piracicaba/SP: Livroceres, 1985.

INSTITUTO DE PESQUISAS TECNOLÓGICAS DO ESTADO DE SÃO PAULO. Orientações para o combate à erosão no Estado de São Paulo: Bacia do Prado Grande> São Paulo, 1990.

KöPPEN, W. Climatología: com un Estúdio de los climas de la Tierra. Fundo de Cultura Económica. México, 1948.

LEPSCH, I. Conservação dos solos. São Paulo: Caderno de textos, 2002.

MAGNAGO, H., SILVA, M. T. M. da, FONZAR, B. C. - Vegetação: as regiões fitoecológicas, sua natureza e seus recursos econômicos. Projeto Radambrasil. (Folha SE.22 - Goiânia). Rio de Janeiro: MME, 1983. (Levantamento de Recursos Naturais 31).

MORETON, Luiz Carlos. Programa Levantamentos geológicos Básicos do Brasil. Iporá. (Folha SE.22-V-B). Escala 1:250.000. Estado de Goiás. Brasília: CPRM, 1999.

SALOMÃO, F. X. de T. Controle e prevenção dos processos erosivos. In: Erosão e Conservação dos solos. Jurandir L. S. Ross (org). São Paulo: Edusp, 1995.

Flávio Alves Souza - Prof. Ms. do curso de geografia da Universidade Estadual de Goiás (UEG) Iporá

Claúdia Valéria Lima - Professora Dra. do curso de geografia da Universidade Federal de Goiás

Recebido para publicação em agosto de 2007 Aceito pra publicação em novembro de 2007 



\title{
Análise sócio-ambiental da região do corredor Paranã-Pireneus - Estado de Goiás
}

\author{
Social-environmental analysis in the Paranã-Pireneus corridor - State of Goiás, Brazil \\ Flávia C. Ribeiro - CTE \\ flavia@cteengenharia.com.br \\ Cristiane da C. Vilela \\ criscvilela@hotmail.com \\ Fátima M. Kowata \\ fatmayumi@gmail.com \\ Manuel E. Ferreira - LAPIG/UFG \\ manuel@iesa.ufg.br
}

\section{RESUMO}

A savana brasileira, localmente conhecida como Cerrado, tem sido caracterizada como um dos ecossistemas mais ameaçados do mundo em termos de biodiversidade, com grande parte da área original convertida em atividades como a pastagem e a agricultura. Diante deste passivo ambiental, a criação de corredores ecológicos tem-se mostrado como uma das alternativas para preservar este ecossistema. Em Goiás, estado onde 0 Cerrado possui a sua maior representação, encontra-se em fase de criação o Corredor Ecológico Paranã-Pireneus, certamente uma das últimas áreas naturais com viabilidade ecológica no bioma Cerrado. Assim, neste trabalho realizamos uma caracterização sócio-ambiental do Corredor Ecológico Paraná-Pireneus, situado na porção nordeste do Estado de Goiás, com uma área aproximada de $66.000 \mathrm{~km}^{2}$. Dentre os resultados principais, apenas 17 municípios no corredor ecológico, de um total de 34, apresentam mais de $50 \%$ de remanescentes de Cerrado. No período de 2001 a 2006, os municípios de Cavalcante e Formosa foram os que mais apresentaram alertas de desmatamentos na área de estudo. Em dissonância com 0 ainda razoável percentual de Cerrado no corredor, esta área apresenta o menor índice de desenvolvimento humano $(0,68)$ quando comparado com as médias estadual $(0,73)$ e nacional $(0,74)$.

Palavras-chave: Cerrado, Análise sócio-ambiental, Corredor Ecológico Paranã-Pireneus.

\section{ABSTRACT}

The Brazilian savanna, locally known as Cerrado, has been characterized as one of threatened ecosystems in the world in terms of its high biodiversity, with a significant part of area converted into anthropic classes like pasture and agriculture. Ahead of this liability, the creation of ecological corridors has been considered as one of the alternatives to preserve this ecosystem. In Goiás, state with the major representation of Cerrado in Brazil, the Paranã-Pireneus Ecological corridor was created, certainly one of the last natural areas with ecological viability in the Cerrado biome. In this work we carryout a socialenvironmental characterization of the Paranã-Pireneus Ecological corridor, situated in the northeast portion of the State of Goiás, with an approach area of $66,000 \mathrm{~km}^{2}$. Amongst the main results, only 17 municipalities units in the ecological corridor (total of 34 ) present $50 \%$ of remnant native vegetation. In the period of 2001 to 2006, the Cavalcante and Formosa municipalities appear with the greater part of deforestations alerts. In disagreement with a still elevated occurrence of native vegetation, the study area presents a lower Human Development Index $(0.68)$ when compared with the state average $(0.73)$ and national average (0.74).

Key-words: Cerrado, socio-environmental analysis, Paranã-Pireneus Ecological Corridor 



\section{Introdução}

O bioma Cerrado é considerado ambientalmente como uma das savanas mais expressivas do mundo (et al., 2000), é dentre os biomas brasileiros, o mais ameaçado pelo uso e ocupação dos solos, sobretudo nas últimas décadas (et al., 1997). Cerca de 40\% de sua área original contínua (208 milhões de hectares) já foram convertidas, sendo normalmente associadas às atividades de pecuária e agricultura (Mantovani \& Pereira, 1998; Sano et al., 2002). Esta rápida transformação da paisagem é favorecida pelos baixos preços de terras na região, topografia favorável à maquinização da agricultura, além de incentivos governamentais como o POLOCENTRO e o PRODECER. Junto a isso, o Cerrado permanece desconhecido quanto ao seu valor ecológico. A sua rica biodiversidade, muitas vezes endêmica, é favorecida pela presença de três das maiores bacias hidrográficas da América do Sul (Paraná-Paraguai, Araguaia-Tocantins e São Francisco), além de uma grande diversidade de solos e geologia (1993).

Diante deste passivo ambiental, os Corredores Ecológicos vêm se compondo como um importante aliado a preservação da biodiversidade, ligado aos conceitos de desenvolvimento econômico e sócio-ambiental. Tais áreas interagem com a movimentação e dispersão de vida selvagem e de fluxo gênico, sustentando a conectividade entre habitats do referido ecossistema. Por outro lado, os corredores ecológicos são também importantes instrumentos de gestão ambiental, pois potencializam a cooperação entre variados níveis de governo e diferentes segmentos da sociedade civil (ex. IBAMA, SEMMA, ONGs, etc.). Assim, um dos principais objetivos de um corredor ecológico é a busca pela preservação da biodiversidade e o desenvolvimento humano (2004).

O presente estudo teve por objetivo caracterizar a região do Corredor Ecológico Paranã-Pireneus quanto aos aspectos políticos e sócio-ambientais. Especificamente, buscou-se analisar, de forma comparativa, os municípios inseridos na região do corredor, por meio de índices de desenvolvimento humano e econômico, além de dados temporais de desmatamentos (2001 a 2006), obtidos por imagens de satélites. 


\section{Fundamentação teórica}

\section{Os Corredores Ecológicos}

Na relação histórica entre sociedade e meio ambiente, são inúmeros os fatores de desequilíbrios ambientais oriundos do desenvolvimento humano, ao mesmo tempo em que cresce a necessidade de se manter os recursos básicos para a sobrevivência dos seres vivos. Esta necessidade ambiental incentiva ações políticas no sentido de se criar áreas legalmente protegidas e representativas da vida silvestre no planeta (et al., 2000).

A transformação dos ambientes naturais em meios antropizados (desmatamentos, queimadas, poluição, urbanização, etc.) acaba por acarretar o isolamento de espécies animais ou vegetais, podendo levar a sua própria extinção. No caso do fragmento florestal, que é definido como qualquer área de vegetação natural contínua interrompido por barreiras antrópicas (estradas, culturas agrícolas, etc.), capazes de diminuir significativamente o fluxo de animais, pólen e/ou sementes (1990).

Constantemente, processos como o de urbanização e expansão da agricultura levam a um aumento nas taxas de desmatamentos, muitas vezes influenciando no isolamento geográfico das espécies de fauna e flora. Quanto menores e mais isolados forem os fragmentos florestais, mais facilmente as populações das espécies animais e vegetais entram em extinção (Ricklefs 1996). A fragmentação elimina o processo de acasalamento dos animais , o que acarreta à degradação dos habitats (Plummer \& Mann, 1995). Dessa forma, os corredores ecológicos passam a ter importância primordial nos programas de conservação da biodiversidade. Em outras palavras, a re-conexão de parte destes habitats isolados é um ponto estratégico para a conservação dos ambientes remanescentes.

Nesta linha de pensamento, os corredores ecológicos agem como conexões entre diferentes ambientes e/ou fragmentos florestais, permitindo o fluxo entre as populações silvestres, diminuindo os efeitos do isolamento e, conseqüentemente, a possibilidade de sobrevivência e manutenção do conjunto de subpopulações conectadas por indivíduos que se movem entre fragmentos (1991). Este corredor pode ser composto de pequenas áreas ambientalmente sustentáveis, tais como parques nacionais, reservas legais nas propriedades rurais, áreas de preservação permanente ao longo de rios e até mesmo as terras indígenas.

Entretanto, a criação de corredores baseia-se na premissa de que as ameaças múltiplas e crescentes para a proteção da biodiversidade exigem 
mais do que o estabelecimento de áreas protegidas, porém isoladas, normalmente cercadas por atividades antrópicas. A gestão inadequada das reservas ambientais e a falta de integração das populações locais tornam as tais áreas alvos de caça, exploração madeireira, mineração, assentamentos rurais, entre outros.

O fundamento legal dos corredores ecológicos encontra-se na lei $\mathrm{n}^{\mathrm{o}}$. 9985/2000 que constitui o SNUC (Sistema Nacional de Unidades de Conservação), e na resolução CONAMA (Conselho Nacional do Meio Ambiente) $n^{\circ}$. 09/1996, sendo o IBAMA (Instituto Brasileiro do Meio Ambiente e dos Recursos Naturais Renováveis) responsável pela implementação de corredores ecológicos no Brasil. Os corredores devem ser dimensionados e administrados para garantir que espécies da fauna e flora possam sobreviver e continuar seus processos biológicos normais (i.e. sobrevivência e reprodução).

A delimitação de corredores ecológicos no Brasil tem sido definida por estudos científicos onde, inicialmente, se avalia a representabilidade dos ecossistemas em relação às unidades de conservação e aos tipos fisionômicos existentes. Os resultados desse estudo determinam o grau de prioridade para a conservação, sem necessariamente passar pelo completo isolamento de partes do ecossistema em questão, mas sim por um manejo adequado das comunidades humanas mais próximas, seguindo as determinações legais para a ocupação e proteção da biodiversidade.

\section{O Corredor Ecológico Paranã-Pireneus}

O Corredor Ecológico Paranã-Pireneus, projeto homônimo em fase de implantação, refere-se a um limite geográfico que engloba parte dos estados de Tocantins, Goiás e Distrito Federal, com uma área aproximada de 10 milhões de hectares. Produto de uma cooperação internacional entre o Brasil (Ministério do Meio Ambiente/IBAMA) e o Japão (JICA - Agência de Cooperação Internacional do Japão).

O projeto tem como finalidade integrar as comunidades locais na área do corredor, com orientação a um manejo sustentável dos recursos naturais, além de capacitar e implementar programas de educação ambiental como forma de garantir a conservação da biodiversidade no bioma Cerrado.

No Estado de Goiás, o Corredor Ecológico Paranã-Pireneus ocupa

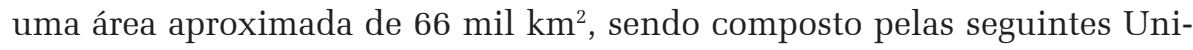
dades de Conservação, conforme (Figura 1). 
1. Região da APA do Pouso Alto / Chapada dos Veadeiros;

2. Região da APA da Serra Geral de Goiás;

3. Região da APA Nascentes do Rio Vermelho;

4. Região da APA do Planalto Central;

5. Região dA APA da Serra dos Pireneus.

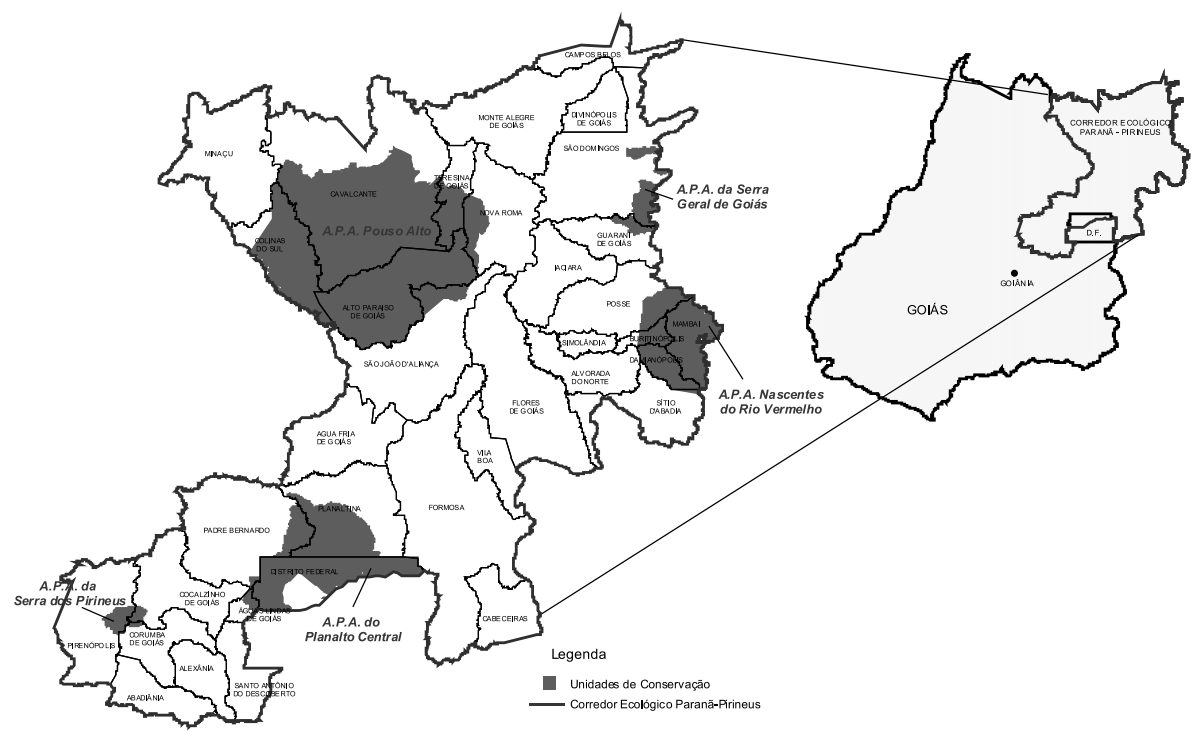

Figura 1. Inserção do Corredor Ecológico Paranã-Pireneus e respectivas Unidades de Conservação no Estado de Goiás.

\section{Abordagem metodológica}

\section{Área de Estudo}

Para os propósitos deste estudo, limitamos as análises ao limite do Corredor Ecológico Paranã-Pireneus, no Estado de Goiás, com uma área aproximada de 66 mil $\mathrm{km}^{2}$. A maior parte do corredor está localizada na região nordeste do estado, compreendida entre as Latitudes Sul $16^{\circ} 07^{\prime} 38$ ” / $12^{\circ} 55^{\prime} 07^{\prime \prime}$ e Longitudes Oeste 49 $11^{\circ} 47^{\prime \prime} / 46^{\circ} 07^{\prime} 06^{\prime \prime}$ (Figura 1).

O Corredor Ecológico Paranã-Pireneus em Goiás é composto por 34 municípios, com uma população de 605 mil habitantes (excluindo-se o Dis- 
trito Federal), sendo 122 mil vivendo na zona rural e 483 mil na zona urbana. O município com a menor densidade demográfica é Cavalcante, com 1,3 hab/ $\mathrm{km}^{2}$, enquanto o maior é Águas Lindas de Goiás, com 549,1 hab/km² (PNUD et al., 2000).

As atividades econômicas que se destacam na região são a pecuária e a agricultura, respectivamente $25,9 \%$ e 5,15\% (SIEG, 2006). O ecoturismo aparece ainda como uma atividade incipiente, mas de grande potencial. Atividades de carvoarias também são atuantes, ainda que de forma ilegal, causando enormes danos ao meio ambiente. De acordo com o IBAMA/GO, Mambaí é o município com o maior número de carvoarias no estado (15), seguido por Flores de Goiás (8) e a exploração já atinge os municípios de Sítio D’Abadia, Damianópolis, Posse e Colinas do Sul (2004).

Especificamente em relação ao ecoturismo, este é realizado normalmente nos parques da região, como o Parque Nacional Chapada dos Veadeiros, Parque Estadual dos Pirineus, Parque Estadual de Terra Ronca, Parque Municipal Ecológico Mata da Bica, Parque Municipal do Distrito de São Jorge, Parque Municipal Abílio Herculano Szervimsks, Parque Municipal Lavapés, todos relevantes, do ponto de vista econômico e ambiental, para os municípios de Alto Paraíso de Goiás, Cavalcante, Pirenópolis, Cocalzinho de Goiás, Corumbá de Goiás, Guarani de Goiás e Formosa.

\section{Base de Dados e Procedimentos de Análise}

Umas das principais bases de dados deste estudo diz respeito às imagens de satélite obtidas pelo sensor MODIS (MODerate resolution Imaging Spectroradiometer), à bordo da plataforma orbital TERRA (mais informações em http://modis.gsfc.nasa.gov/; Ferreira et al., 2006a; Ferreira et al., 2007). Dentre os produtos do MODIS, foi utilizado o MOD13Q1 (imagens índice de vegetação NDVI, 250 metros, 16 dias), disponibilizado gratuitamente pela internet no portal EOS/NASA (http://edcimswww.cr.usgs.gov/pub/imswelcome/). Estas imagens são fornecidas com georeferenciamento e corrigidas para os efeitos atmosféricos (nuvens, aerossóis e sombras).

As cenas MODIS (órbita/ponto h13v10), referente ao período de 2001 a 2006 (sempre no mês de outubro), foram processadas pelo Sistema Integrado de Alerta de Desmatamentos (SIAD) com o objetivo de detectar mudanças na cobertura vegetal (possíveis desmatamentos) para a área de estudo (mais informações em http://www.lapig.iesa.ufg.br/siadgoias/; Ferreira et al., 2004; Ferreira et al., 2006b). 
Para a detecção dos possíveis desmatamentos, foram adotadas as seguintes regras: área mínima de 50 hectares (área mínima de mudança na paisagem a ser detectada) e o limiar de mudança na paisagem de $30 \%$ (i.e. alteração mínima na cobertura vegetal a ser detectada). Nesta etapa de detecção, somente as imagens índice de vegetação NDVI (Normalized Difference Vegetation Index ou Índice de Vegetação por Diferença Normalizada) são analisadas, buscando-se a redução da biomassa entre duas datas (ex. outubro ano 1 - outubro ano 2).

Assim, o procedimento foi repetido para os anos 2001 - 2002, 2002 2003, 2003 - 2004, 2004 - 2005 e 2005 - 2006, completando-se os períodos de análise. Por fim, todos os prováveis desmatamentos detectados para todo o estado de Goiás foram filtrados de acordo com o limite do Corredor Ecológico Paranã-Pireneus (área de estudo).

Os dados de prováveis desmatamentos foram integrados com outras bases de dados de Goiás (restritas à área de estudo), tais como o mapa de limite político municipal e o mapa de uso do solo e de remanescentes vegetais para o estado. Especificamente ao mapa de cobertura vegetal, o mesmo tratase de uma compilação dos dados digitais elaborados no âmbito do projeto "Identificação de Áreas Prioritárias para a Conservação da Biodiversidade no Estado de Goiás” (Consórcio WWF/Imagem, sob coordenação da Agência Goiana de Meio Ambiente), na escala original 1:250.000 (Sano et al., 2006), disponibilizados atualmente nos Sistemas de Informações Estatísticas e Geográficas do Estado de Goiás (SIEG - www.sieg.go.gov.br).

Outra base de dados importante para a complementação deste estudo foi a análise sócio-econômica para os municípios goianos no corredor Paranã-Pireneus, representado aqui pelo Índice de Desenvolvimento Humano (IDH), Índice de Pobreza e Índice de GINI (referentes ao ano de 2000). Estes dados foram extraídos do Atlas de Desenvolvimento Humano no Brasil (PNUD et al., 2002), espacializados para os municípios em questão, e correlacionados com os valores de desmatamentos para os períodos analisados.

Numa breve descrição dos índices estudados, o IDH é um indicador elaborado pelo Programa das Nações Unidas para o Desenvolvimento (PNUD), o qual sintetiza três índices: escolaridade, renda per capta e longevidade. O intervalo de valores varia entre 0 (zero) e 1, onde 0 representa o mais baixo cenário de desenvolvimento, e 1 o mais alto cenário de desenvolvimento.

O Índice de Pobreza varia de 0 a 100\%, indicando a proporção de pessoas vivendo abaixo da linha de pobreza no Brasil, fixada (em R \$) de acordo com a metade do valor de um salário mínimo no país (em 2000, esta linha de pobreza correspondia a $\mathrm{R} \$ 75,00)$. 
O Índice de GINI descreve a concentração de renda para uma dada sociedade, onde 0 (zero) representaria, de forma hipotética, uma renda igualmente distribuída entre os indivíduos, e, 1 indicaria a concentração de toda a renda por um único indivíduo.

Todas as análises foram realizadas nos Sistemas de Informações Geográficas (SIG), empregando-se os softwares ArcGIS (ESRI) e ENVI (RSI), disponibilizados pelo Laboratório de Processamentos de Imagens e Geoprocessamento da Universidade Federal de Goiás (LAPIG/UFG).

\section{Resultados}

\section{Análise dos Desmatamentos}

Em relação às mudanças na paisagem observadas pelo SIAD para a região do Corredor Ecológico Paranã-Pireneus, no Estado de Goiás, detectouse a área de possíveis desmatamentos conforme metodologia descrita, para o período histórico entre 2001 e 2006. A tabela 1 indica a área destas detecções, por município.

Tabela 1. Área dos prováveis desmatamentos ocorridos no Corredor Ecológico Paranã-Pireneus, entre 2001 e 2006. Dados obtidos pelo Sistema Integrado de Alerta de Desmatamentos (SIAD - Goiás).

\begin{tabular}{|c|c|c|c|c|c|c|c|}
\hline \multirow{2}{*}{ Município } & \multirow{2}{*}{$\begin{array}{r}\text { Área } \\
\left(\mathrm{km}^{2}\right)\end{array}$} & \multirow{2}{*}{$\begin{array}{l}\text { Remanescente } \\
\text { de Cerrado (\%) }\end{array}$} & \multicolumn{5}{|c|}{ Desmatamento $\left(\mathrm{km}^{2}\right)$} \\
\hline & & & $\begin{array}{r}2001 / \\
2002\end{array}$ & $\begin{array}{r}2002 / \\
2003\end{array}$ & $\begin{array}{r}2003 / \\
2004\end{array}$ & $\begin{array}{r}2004 / \\
2005\end{array}$ & $\begin{array}{r}2005 / \\
2006 \\
\end{array}$ \\
\hline Abadiânia & $1.047,70$ & $39,91 \%$ & 0,00 & 41,30 & 1,65 & 0,08 & 0,00 \\
\hline Água Fria de Goiás & $2.036,70$ & $48,87 \%$ & 140,72 & 117,69 & 29,64 & 13,93 & 1,72 \\
\hline Águas Lindas de Goiás & 191,90 & $63,91 \%$ & 1,27 & 3,33 & 1,32 & 0,00 & 0,00 \\
\hline Alexânia & 850,80 & $59,16 \%$ & 2,42 & 26,36 & 6,20 & 1,45 & 1,43 \\
\hline Alto Paraíso de Goiás & $2.603,40$ & $84,13 \%$ & 191,82 & 113,17 & 143,97 & 1,11 & 3,06 \\
\hline Alvorada do Norte & $1.296,60$ & $47,73 \%$ & 13,20 & 15,48 & 5,27 & 3,44 & 0,00 \\
\hline Buritinópolis & 269,10 & $21,93 \%$ & 0,00 & 0,96 & 0,00 & 0,00 & 0,00 \\
\hline Cabeceiras & $1.117,40$ & $29,61 \%$ & 5,62 & 5,62 & 1,98 & 4,30 & 0,00 \\
\hline Campos Belos & 785,80 & $23,07 \%$ & 12,22 & 3,01 & 12,91 & 0,73 & 3,18 \\
\hline Cavalcante & $6.979,50$ & $90,48 \%$ & 531,25 & 311,12 & 212,82 & 52,97 & 49,12 \\
\hline
\end{tabular}




\begin{tabular}{|l|r|r|r|r|r|r|r|}
\hline Cocalzinho de Goiás & $1.794,30$ & $72,61 \%$ & 21,59 & 79,93 & 25,14 & 6,12 & 0,00 \\
\hline Colinas do Sul & $1.714,50$ & $78,05 \%$ & 156,53 & 13,83 & 124,69 & 4,78 & 0,00 \\
\hline Corumbá de Goiás & $1.066,20$ & $49,38 \%$ & 2,32 & 28,04 & 4,80 & 0,00 & 0,00 \\
\hline Damianópolis & 416,90 & $32,38 \%$ & 0,83 & 1,22 & 0,00 & 0,00 & 0,00 \\
\hline Divinópolis de Goiás & 834,30 & $77,03 \%$ & 5,74 & 51,86 & 9,60 & 0,00 & 6,41 \\
\hline Flores de Goiás & $3.722,80$ & $61,44 \%$ & 20,89 & 140,48 & 52,72 & 3,66 & 0,00 \\
\hline Formosa & $5.827,70$ & $50,66 \%$ & 280,32 & 103,32 & 283,43 & 34,49 & 7,18 \\
\hline Guarani de Goiás & $1.233,80$ & $56,54 \%$ & 14,51 & 68,69 & 19,55 & 0,56 & 0,00 \\
\hline Iaciara & $1.631,30$ & $48,93 \%$ & 0,00 & 286,07 & 19,57 & 0,00 & 0,00 \\
\hline Mambaí & 862,70 & $41,35 \%$ & 12,50 & 10,97 & 16,83 & 19,30 & 4,30 \\
\hline Minaçu & $2.871,60$ & $39,28 \%$ & 339,73 & 48,58 & 94,10 & 7,82 & 5,57 \\
\hline Monte Alegre de Goiás & $3.131,50$ & $55,17 \%$ & 47,76 & 444,56 & 42,33 & 5,63 & 1,45 \\
\hline Nova Roma & $2.143,90$ & $77,50 \%$ & 123,90 & 56,82 & 18,90 & 1,26 & 3,96 \\
\hline Padre Bernardo & $3.148,90$ & $48,68 \%$ & 80,95 & 110,25 & 90,51 & 1,66 & 1,65 \\
\hline Pirenópolis & $2.189,40$ & $23,29 \%$ & 67,84 & 14,91 & 46,35 & 0,00 & 1,66 \\
\hline Planaltina & $2.547,70$ & $73,02 \%$ & 123,34 & 123,47 & 123,35 & 28,44 & 16,37 \\
\hline Posse & $1.961,90$ & $43,16 \%$ & 12,35 & 193,67 & 7,05 & 1,28 & 5,30 \\
\hline Sto Antônio do & 941,60 & $30,95 \%$ & 11,10 & 86,20 & 30,58 & 0,80 & 0,77 \\
\hline Descoberto & $3.308,00$ & $62,14 \%$ & 16,57 & 364,08 & 51,04 & 9,62 & 15,40 \\
\hline São Domingos & $3.339,50$ & $72,91 \%$ & 256,49 & 58,82 & 196,20 & 1,22 & 6,33 \\
\hline Simolândia d'Aliança & 344,00 & $71,77 \%$ & 0,00 & 54,04 & 0,00 & 0,00 & 0,00 \\
\hline Sítio d'Abadia & $1.571,50$ & $42,71 \%$ & 1,81 & 22,22 & 9,20 & 1,72 & 0,00 \\
\hline Teresina de Goiás & 777,50 & $99,44 \%$ & 35,46 & 4,63 & 12,69 & 1,36 & 2,46 \\
\hline Vila Boa & $1.064,00$ & $41,84 \%$ & 17,13 & 23,52 & 6,03 & 0,00 & 0,00 \\
\hline Total & $65.624,40$ & $59,36 \%$ & $2.548,20$ & $3.028,24$ & $1.700,43$ & 207,73 & 137,32 \\
\hline
\end{tabular}

* Municípios no Corredor Ecológico Paranã-Pireneus, no Estado de Goiás.

Em análise aos dados da tabela 1, no período de 2001 a 2006, os municípios de Cavalcante e Formosa foram os que mais apresentaram desmatamentos na área de estudo, com 1.157,28 km² e 708,74 km², respectivamente. Foi verificada também uma queda significativa da área de prováveis desmatamentos nesta região. Vários motivos podem explicar tal redução, dentre estes uma maior repressão dos órgãos de defesa ambiental (federal e estadual) às ações ilegais de desmatamentos, sobretudo nas áreas utilizadas por carvoarias. Alterações na economia neste período, com influência nos 
preços de commodities agrícolas (maiores quedas no ano de 2005), também favoreceram a esta redução nos desmatamentos. Somado a estes motivos, ocorreram ainda mudanças sazonais no Cerrado, possivelmente com anos mais secos ou chuvosos, o que influi na quantidade de detecções para cada período analisado. A figura 2 ilustra a distribuição das detecções na área de estudo.

Como era o esperado para a região mais preservada em termos ecológicos no Estado de Goiás, todos os 34 municípios apresentam, pelo menos, 20\% de sua área com remanescentes de Cerrado. Destes 34, apenas 17 apresentam uma área de remanescentes superior a 50\%, com destaque para os municípios de Teresina de Goiás e Cavalcante, que ainda possuem mais de $90 \%$ de sua cobertura vegetal nativa.

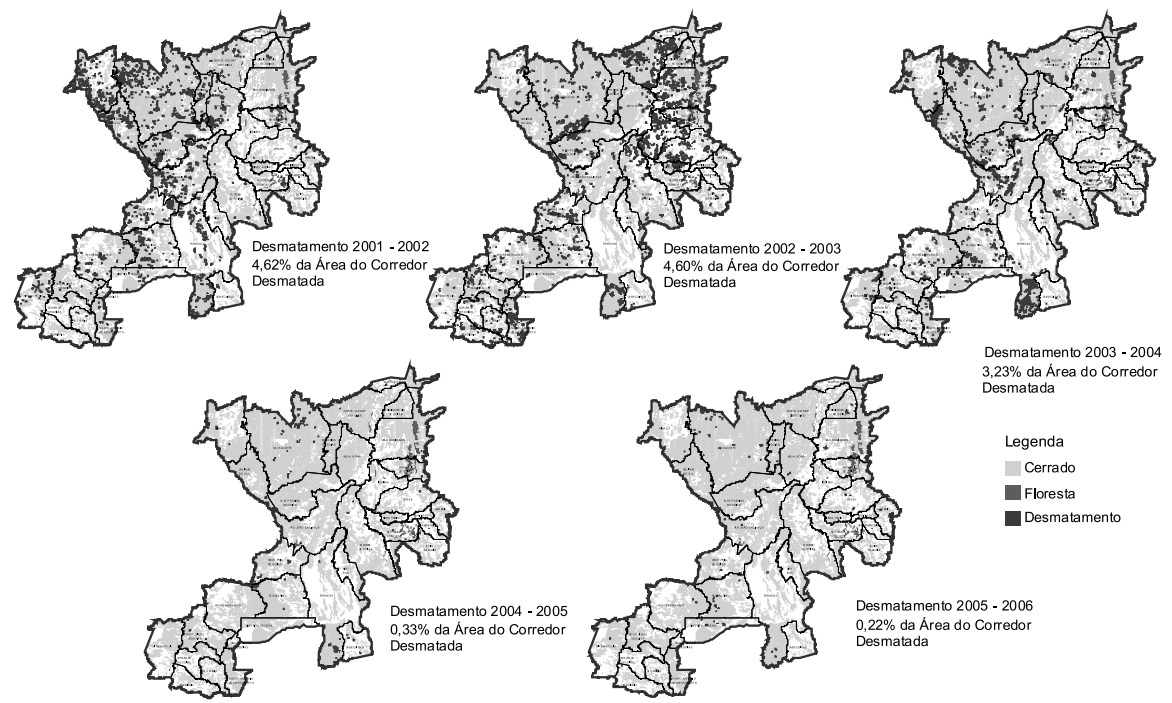

Figura 2. Distribuição dos prováveis desmatamentos no Corredor Ecológico Paranã-Pireneus no Período de 2001 a 2006, detectadas pelo SIAD.

O relevo acidentado, com áreas de acentuada declividade, é um fator natural que dificulta o avanço da agricultura mecanizada e da pastagem cultivada, favorecendo a preservação da cobertura vegetal nativa (et al., 2006c). A própria política de desenvolvimento do estado mantém esta região mais isolada em detrimento dos grandes centros produtores de Goiás, como Rio Verde e Goiânia. A figura 3 ilustra as classes de uso do solo e cobertura vegetal nativa para a área de estudo. 


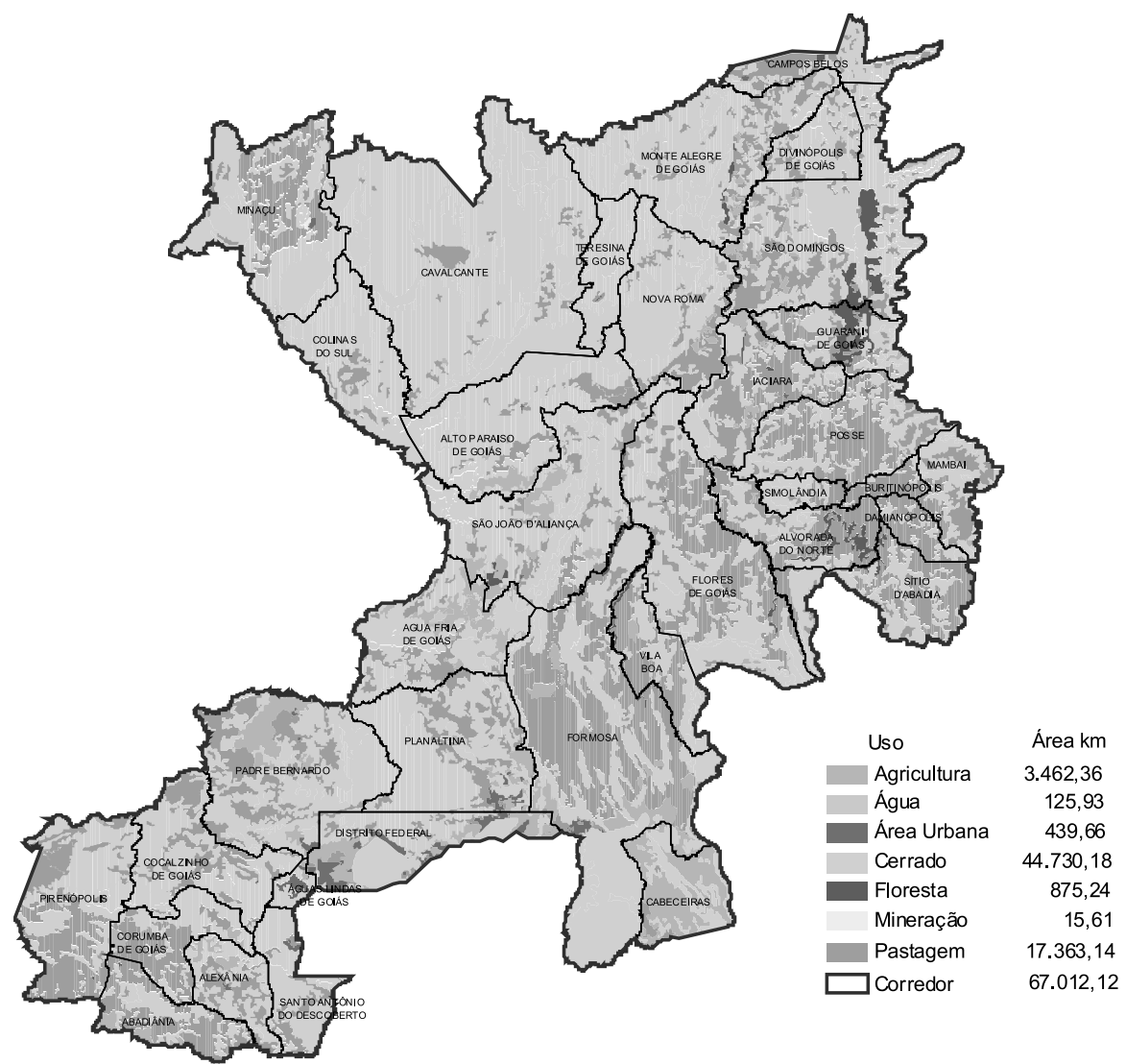

Figura 3. Uso do solo e cobertura vegetal nativa para o Corredor Ecológico Paranã-Pireneus. Fonte: base de dados do PDIAP (Sano et al., 2006).

\section{Análise Sócio-Econômica}

Especificamente em relação às análises sócio-econômicas, em geral os indicadores para esta região do corredor apontam, em média, um Índice de Desenvolvimento Humano Municipal (IDH-M) de 0,68, Índice de GINI de 0,60 e Intensidade de Pobreza de 50,9\%.

Com base na tabela 2, a qual compara os valores médios destes três índices com os demais municípios de Goiás e para o país como um todo, os índices obtidos para o corredor exibem um cenário preocupante e, ao 
mesmo tempo, desafiador, a medida em que estes apresentam os menores valores de IDH e maior proporção de pobres.

Tabela 2. Comparação do IDH-M, Índice de GINI e Intensidade de Pobreza para a área de estudo e demais localidades.

\begin{tabular}{|l|c|c|c|}
\hline \multicolumn{1}{|c|}{ LOCALIDADES } & IDH-M & Índice de GINI & Intensidade de Pobreza \\
\hline Corredor Ecológico Paranã-Pireneus (GO) & 0,68 & 0,60 & 50,90 \\
\hline Restante dos municípios de Goiás (GO) & 0,74 & 0,56 & 37,97 \\
\hline Brasil & 0,74 & 0,64 & 48,92 \\
\hline
\end{tabular}

Fonte: ATLAS do Desenvolvimento Humano. (valores médios para o ano de 2000).

Numa análise estadual, municípios como Goiânia e Rio Verde, com IDH-M de 0,83 e 0,81, respectivamente, apresentam estes valores acima da média estadual $(0,73)$ e nacional $(0,74)$, diferentemente dos municípios presentes na região do Corredor Ecológico Paranã-Pireneus, com IDH-M médio de 0,68. O mapa na figura 4 ilustra tal distribuição do IDH-M para o estado e corredor.

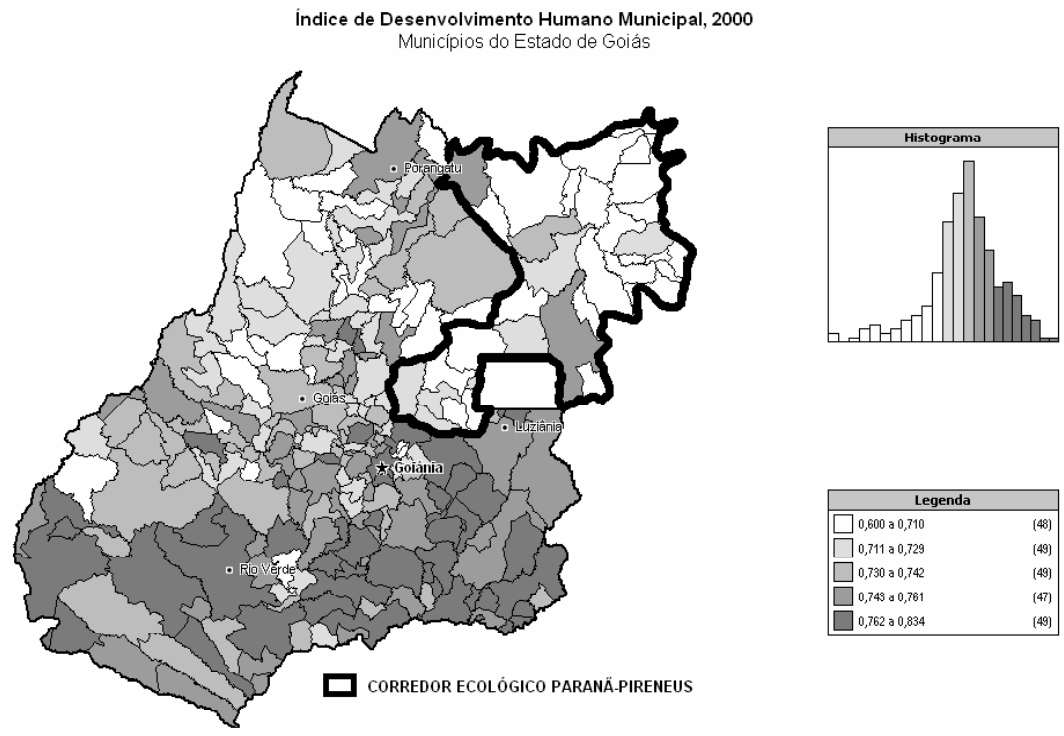

Figura 4. IDH-M para o Estado de Goiás, com destaque para o limite do Corredor Ecológico Paranã-Pireneus. 
Para uma melhor avaliação, dividiu-se a análise do Índice de Desenvolvimento Humano Municipal (IDH-M) em seus três componentes (educação, longevidade e renda per capta), como observado na tabela 3.

Pode-se observar que os valores médios do IDH-M na região do corredor (análise individual dos três componentes) estão abaixo da média estadual. Dentre estes componentes, o mais crítico é a renda per capta, apresentando média de 0,59 , enquanto que o menos crítico é o da educação, com média de 0,77, ainda abaixo da média das localidades de Brasília/DF (0,94), Goiânia $(0,93)$ e Rio Verde $(0,87)$.

Tabela 3. Índice de Desenvolvimento Humano Municipal (IDH-M, ano 2000), dividido em seus três componentes: educação, longevidade e renda per capta.

\begin{tabular}{|l|c|c|c|c|}
\hline \multicolumn{1}{|c|}{ LOCALIDADES } & IDH-M & $\begin{array}{c}\text { IDH-M } \\
\text { Educação }\end{array}$ & $\begin{array}{c}\text { IDH-M } \\
\text { Longevidade }\end{array}$ & $\begin{array}{c}\text { IDH-M } \\
\text { Renda }\end{array}$ \\
\hline Corredor Ecológico Paranã-Pireneus (GO) & 0,68 & 0,77 & 0,69 & 0,59 \\
\hline Goiânia (GO) & 0,83 & 0,93 & 0,75 & 0,81 \\
\hline Rio Verde (GO) & 0,81 & 0,87 & 0,80 & 0,75 \\
\hline Brasília (DF) & 0,84 & 0,94 & 0,76 & 0,84 \\
\hline Estado de Goiás & 0,73 & 0,82 & 0,73 & 0,65 \\
\hline Brasil & 0,74 & 0,83 & 0,71 & 0,68 \\
\hline
\end{tabular}

Fonte: ATLAS do Desenvolvimento Humano (valores médios para o ano de 2000).

Percebe-se, através da figura 5 que, a necessidade de geração de renda é um ponto crucial na maioria dos municípios que fazem parte do Corredor Ecológico Paranã-Pireneus, destacando-se, nesta situação, o município de Buritinópolis, que possui indicador abaixo de 0,50, ou seja, um nível bastante baixo para as médias estaduais e nacionais de IDH aceitáveis.

No tocante à educação, a situação dos municípios é mais promissora, com indicadores acima de 0,50. O município de Cavalcante é o que possui o menor índice de IDH-M Educação $(0,60)$. Esta categoria pode ser analisada pela figura 6. 

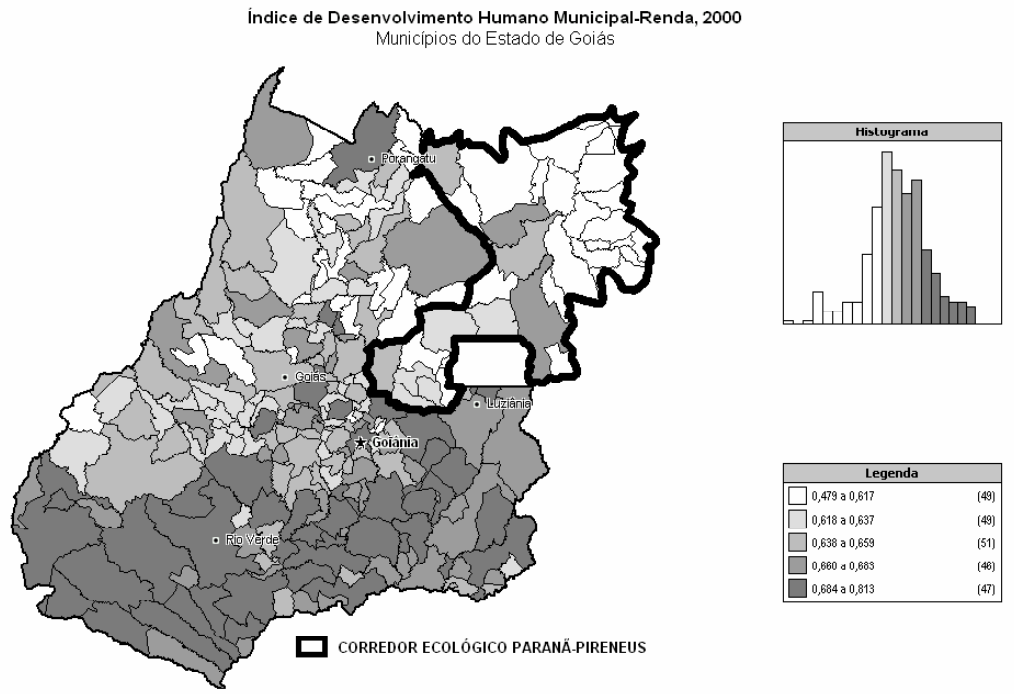

Figura 5. IDH-M, categoria Renda per capta, para o Estado de Goiás, com destaque para o limite do Corredor Ecológico Paranã-Pireneus.

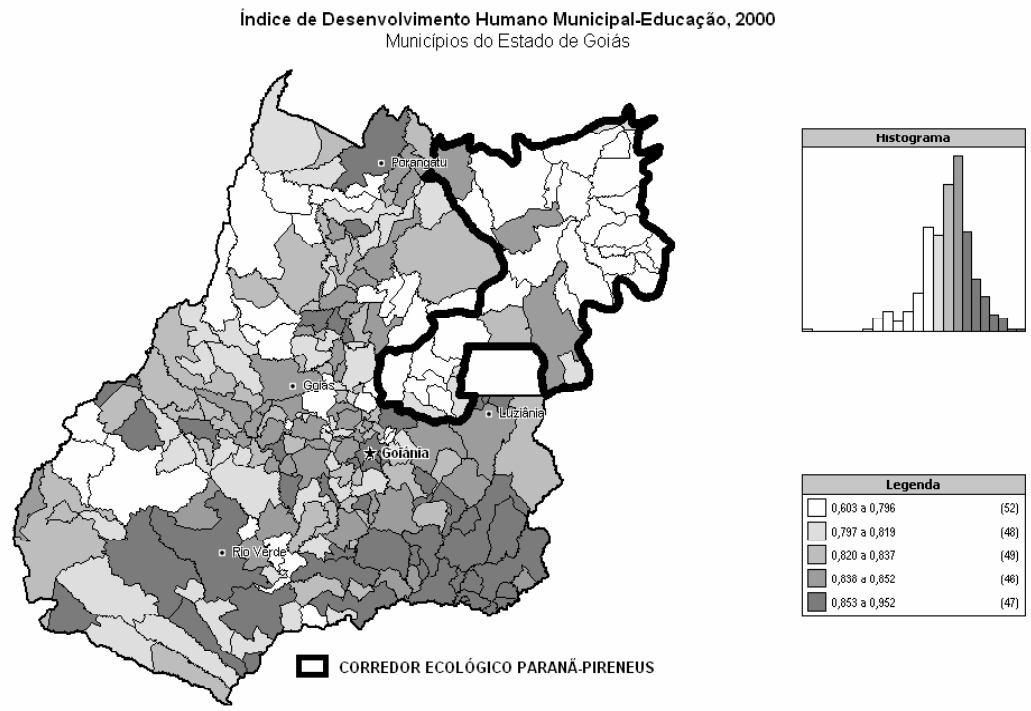

Figura 6. IDH-M, categoria Educação, para o Estado de Goiás, com destaque para o limite do Corredor Ecológico Paranã-Pireneus. 
Analisando o componente Longevidade, este se encontra numa situação mais próxima da média brasileira, com 0,69. Grande parte da região do corredor apresenta valores de longevidade baixos a médios, assim como o noroeste do estado de Goiás, em comparação aos valores mais altos para o restante do estado, conforme demonstrado pela figura 7.

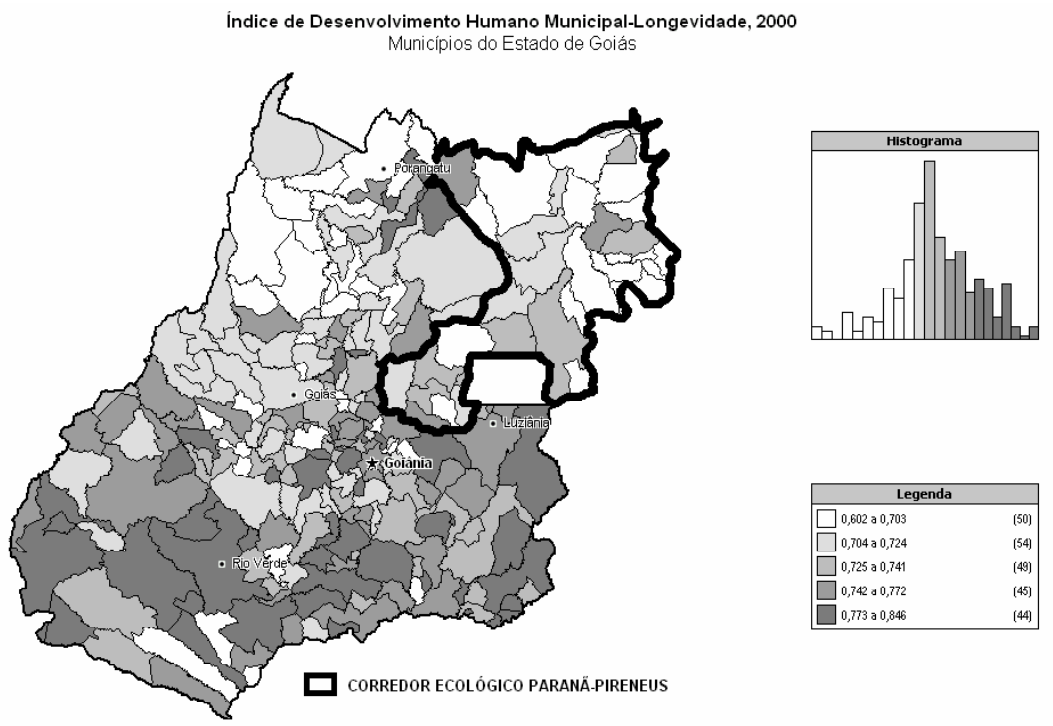

Figura 7. IDH-M - categoria Longevidade, para o Estado de Goiás, com destaque para o limite do Corredor Ecológico Paranã-Pireneus.

O Índice de GINI no Corredor Ecológico Paranã-Pireneus é de 0,60, isto é, acima da média estadual $(0,56)$, mas abaixo da média nacional $(0,64)$. Para este índice, quanto mais alto este valor, maior a concentração de renda. No momento, pode-se afirmar que a concentração de renda nos municípios do corredor ecológico está mais elevada do que deveria.

O município de Rio Verde (GO) apresenta o mesmo Índice de GINI $(0,60)$, enquanto Goiânia (GO) e Brasília (DF) apresentam médias mais altas do que aquelas do Corredor Ecológico Paranã-Pireneus, isto é, 0,61 e 0,64, respectivamente. A figura 8 ilustra tal distribuição.

A Intensidade da Pobreza na região do corredor ecológico apresenta média de 50,90\%, muito acima da média estadual $(39,79)$ e nacional $(48,92)$. Comparando-se com outras regiões mais desenvolvidas de Goiás, como Goiânia e Rio Verde, além de Brasília (DF), a região do corredor é a que, contra- 
ditoriamente, apresenta maior intensidade de pobreza e a maior cobertura remanescente de Cerrado.

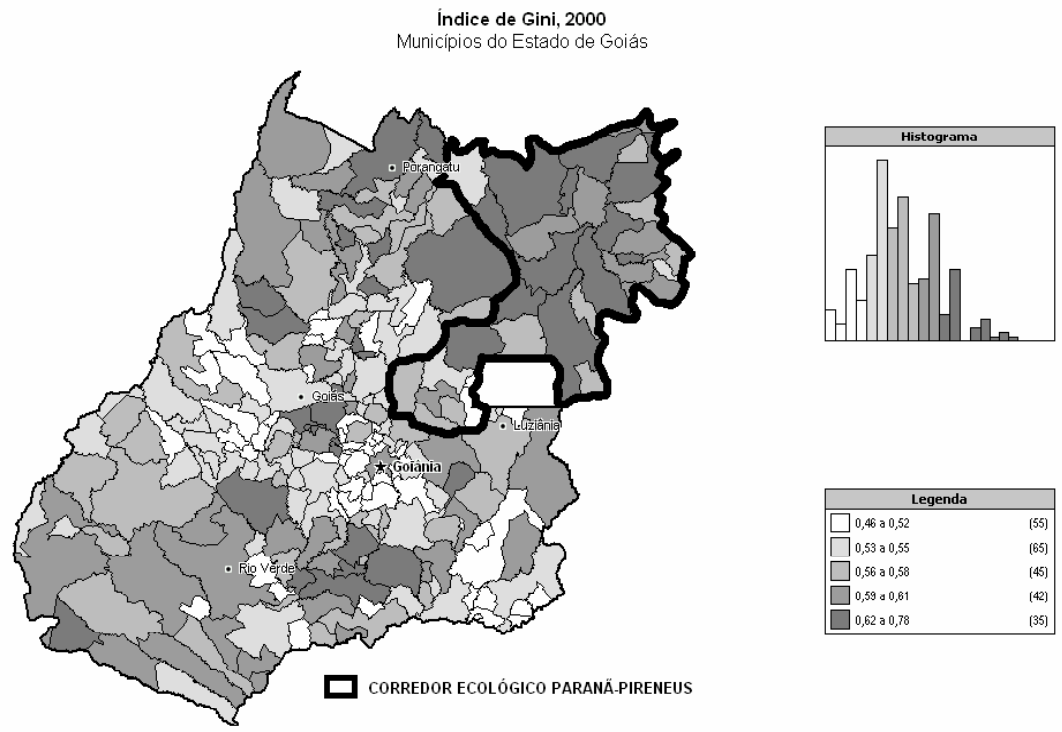

Figura 8. Índice de GINI para o Estado de Goiás, com destaque para o limite do Corredor Ecológico Paranã-Pireneus.

Estes dados, listados na tabela 4, assim como os demais apresentados, indicam que o chamado desenvolvimento sustentável ainda não ocorre verdadeiramente no Estado de Goiás, justamente porque as regiões mais desenvolvidas e com menor intensidade de pobres são justamente aquelas com maior grau de degradação do Cerrado e vice-versa. Por outro lado, a região de Rio Verde, por exemplo, apresenta um índice de GINI tão alto quanto àquele observado na região nordeste do estado (área do corredor ecológico), ou seja, as desigualdades persistem apesar do elevado desenvolvimento. Tão pouco vem sendo valorizada as localidades que mais preservam o Cerrado, caso dos municípios no corredor ecológico, os quais apresentam os valores de renda mais baixos do estado (tabela 3 ) e a intensidade de pobreza mais elevada (figura 9).

Assim, Novaes et al. (2006) discorrem sobre o assunto:

Em síntese, as populações mais empobrecidas do Estado podem, de forma significativa, ser encontradas nos locais com maior proporção de vegetação nativa. 
Mais ainda, quanto mais intensa essa pobreza, ou quanto mais pobres os pobres, independente da proporção de pobres na população, também maior é a presença de vegetação.

Tabela 4. Comparação do Índice de GINI e Intensidade de Pobreza para a área de estudo e demais localidades.

\begin{tabular}{|l|c|c|}
\hline \multicolumn{1}{|c|}{ LOCALIDADE } & Índice de GINI & Intensidade da Pobreza \\
\hline Corredor Ecológico Paranã-Pireneus (GO) & 0,60 & 50,90 \\
\hline Goiânia (GO) & 0,61 & 38,87 \\
\hline Rio Verde (GO) & 0,60 & 36,21 \\
\hline Brasília (DF) & 0,64 & 42,23 \\
\hline Goiás & 0,56 & 39,79 \\
\hline Brasil & 0,64 & 48,92 \\
\hline
\end{tabular}

Fonte: ATLAS do Desenvolvimento Humano (valores médios para o ano de 2000).
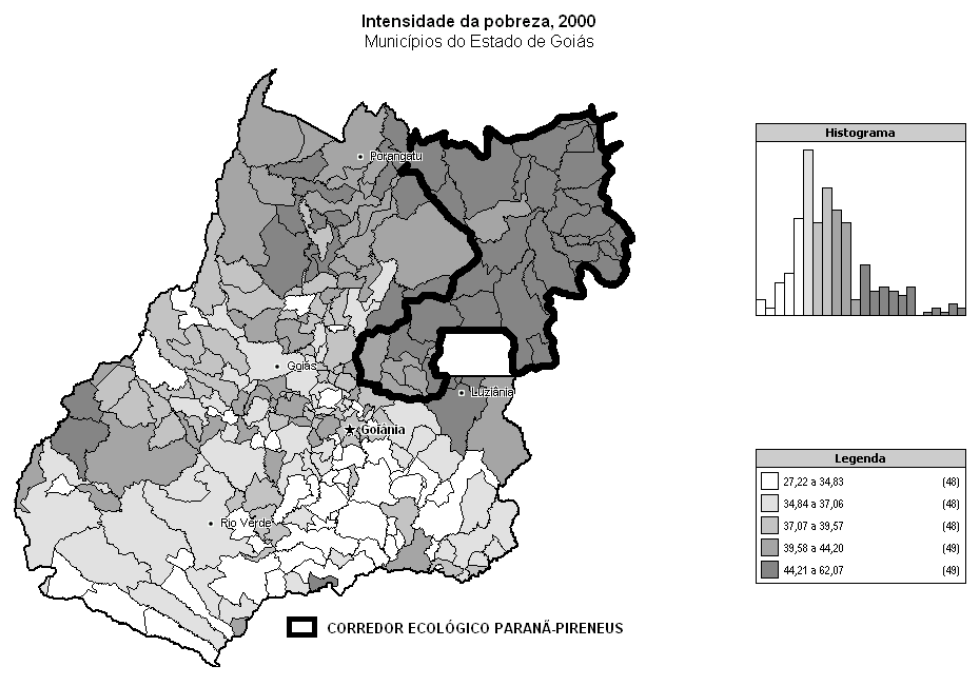

Figura 9. Intensidade de Pobreza para o Estado de Goiás, com destaque para o limite do Corredor Ecológico Paranã-Pireneus.

Quando confrontamos os dados sócio-econômicos com os de prováveis desmatamentos nos períodos analisados (tabela 5), observa-se que o município de Cavalcante apresentou em 2005/2006 a maior área de desma- 
tamento, correspondendo a 0,70\% da sua área geográfica. Este município é também o de maior Intensidade de Pobreza (60\%), o de menor Índice de Desenvolvimento Humano Municipal $(0,61)$, estando entre os municípios que possuem o maior índice de GINI $(0,63)$.

Por outro lado, o município de Nova Roma possui a menor área desmatada entre os 10 municípios listados (tabela 4), possui IDH-M igual à média do Corredor Ecológico Paranã-Pireneus $(0,68)$, com Índice de GINI $(0,59)$ abaixo da média de 0,60 . A Intensidade de Pobreza $(52,10)$ ainda está acima da média do corredor ecológico de 50,90.

Ainda com base na tabela 5, verifica-se que a grande parte dos prováveis desmatamentos que vem sendo realizada na região do Corredor Ecológico Paranã-Pireneus não resulta, necessariamente, em aumento de renda da população local. Portanto, o desmatamento não é condição sine qua non do crescimento econômico da região (Novaes et al., 2006).

Entretanto, os dados demonstram que a pobreza tão pouco é um fator significativo para a degradação ambiental no Corredor Ecológico ParanáPireneus. A maior presença de pobres na região pode estar contribuindo para a manutenção do Cerrado, já que eles próprios seriam os maiores prejudicados pela degradação deste meio ambiente (maior dependência dos rios e das matas preservadas).

Tabela 5. Lista dos 10 municípios com o maior de desmatamento no período de 2005/2006, em ordem decrescente.

\begin{tabular}{|c|c|c|c|c|c|}
\hline Município & $\begin{array}{c}\text { Desmatamento } \\
2005 / 2006 \\
\left(\mathrm{~km}^{2}\right)\end{array}$ & $\begin{array}{c}\text { Desmatamento } \\
2005 / 2006 \\
(\%)\end{array}$ & IDH-M & Índice de GINI & $\begin{array}{l}\text { Intensidade da } \\
\text { Pobreza }\end{array}$ \\
\hline Cavalcante & 49,12 & $0,70 \%$ & 0,61 & 0,63 & 60,00 \\
\hline Planaltina & 16,37 & $0,64 \%$ & 0,72 & 0,56 & 49,76 \\
\hline São Domingos & 15,40 & $0,47 \%$ & 0,63 & 0,63 & 57,57 \\
\hline Formosa & 7,18 & $0,12 \%$ & 0,75 & 0,63 & 51,19 \\
\hline Divinópolis de Goiás & 6,41 & $0,77 \%$ & 0,68 & 0,56 & 51,46 \\
\hline São João d'Aliança & 6,33 & $0,19 \%$ & 0,72 & 0,70 & 47,41 \\
\hline Minaçu & 5,57 & $0,19 \%$ & 0,75 & 0,54 & 51,85 \\
\hline Posse & 5,30 & $0,27 \%$ & 0,71 & 0,60 & 50,34 \\
\hline Mambaí & 4,30 & $0,50 \%$ & 0,65 & 0,56 & 52,82 \\
\hline Nova Roma & 3,96 & $0,18 \%$ & 0,68 & 0,59 & 52,10 \\
\hline
\end{tabular}

Fonte: ATLAS do Desenvolvimento Humano (valores médios para o ano de 2000). 


\section{Considerações finais}

De um modo geral, considera-se que o estado de pobreza de uma população leva à degradação ambiental. Todavia, em certas circunstâncias, como as que se verificam no Corredor Ecológico Paraná-Pireneus, o "atraso econômico" e a pobreza podem ter contribuído para certa forma de preservação. A população ainda é reduzida e isolada, com a principal atividade sendo a pecuária bovina praticada em pastagens naturais. Até a pouco tempo atrás, a população local retirava do Cerrado o que precisavam para subsistência, e não pensando em fins comerciais (ex. atividades madeireiras e carvoarias).

Atualmente, com a chegada do "progresso", a região passa a sofrer as conseqüências de um novo tipo de ocupação do solo, aumentando a pressão sobre os recursos naturais, com destaque para a cobertura nativa e os rios.

Uma auditoria recente feita pela AGMA constatou que as carvoarias estão servindo como intermediárias de grandes siderúrgicas para burlar a Lei Florestal e garantir a produção de carvão a baixo custo, empregando-se mão-de-obra barata (quando não escrava), sem qualquer preocupação com a preservação ambiental (Sano et al. 2006). Houve também a exploração de outras espécies, como a do Pequi, na região de Mambaí, e das sempre-vivas, na Chapada dos Veadeiros. Nessa fase, portanto, a falta de educação ambiental, aliada à pobreza da população local, deixa de “contribuir” para a preservação, com o registro cada vez mais freqüente de desmatamentos servindo a madeireiras ou carvoarias.

Nas regiões de Nova Roma, Iaciara, São João d'Aliança e Flores de Goiás já se torna comum a instalação de grandes e modernas fazendas de gado (ou frigoríficos), as quais aumentam a área de pastagem cultivada de forma extensiva. Com o avanço das lavouras comerciais, municípios como Flores de Goiás, Sítio d'Abadia e Alvorada do Norte passam a perder grandes áreas de Cerrado ou matas para implantar as lavouras mecanizadas de soja, por exemplo.

Para impedir o avanço na degradação do Cerrado em Goiás, se faz urgente a implantação e conservação do Corredor Ecológico Paranã-Pireneus, onde se localizam a maior parte de remanescente do estado.

Por fim, o sucesso de projetos como o do Corredor Ecológico ParanãPireneus é possível se forem adotadas estratégias voltadas para o desenvolvimento social da população local, valorizando o esclarecimento desta quanto à importância de se preservar a biodiversidade do Cerrado. 


\section{Agradecimentos}

Esta pesquisa contou com o apoio de dados e softwares do Laboratório de Processamento de Imagens e Geoprocessamento da Universidade Federal de Goiás (LAPIG/UFG). O $4^{\circ}$ autor é bolsista do Conselho Nacional de Desenvolvimento Científico e Tecnológico (CNPq).

\section{Referências}

Arruda, M. B., Dias, A., Latrubesse, E. M., Galinkin, M., Mendonça, A. F., Scardua, F. Projeto Corredor Ecológico Bananal - Araguaia. Brasília, DF. 2000.

Cardoso, E. S., Corrêa, R. S. Identificação de Corredores Ecológicos no Distrito Federal. In Anais do IV Congresso Brasileiro de Unidades de Conservação (pp. 241-249). Curitiba, PR. 2004.

Cerrado Vivo. Jornal da Reserva Particular do Patrimônio Natural. Publicação Trimestral do Projeto PNUD BRA/00/G35. Ano 2, n. 6 (pp. 1-4). Brasília, DF: Fundação FUNATURA. 2004.

Eiten G. (1993). Cerrado’s vegetation. In M. N. Pinto (Ed.), Cerrado: caracterização, ocupação e perspectivas (pp. 17-73). Brasília, DF: Ed. Universidade de Brasília.

Ferreira, L. G., Silva, A. A., Jesus, E. T. de, Sano, E. E., Shimabukuro, Y. E. Monitoramento Sistemático da Cobertura Vegetal no Bioma Cerrado através dos Índices de Vegetação Modis. In Anais XI SBSR (pp. 2729-2736). Belo Horizonte, MG: INPE. 2003.

Ferreira, M. E., Gomes, M. P., Aguiar, M. C. de, Ferreira, N. C., Ferreira Jr., L. G. Sistema Integrado de Alerta de Desmatamentos (SIAD) para o bioma Cerrado: uma nova abordagem para monitoramento sistemático e efetivo da região. In Anais $10^{\circ}$ Simpósio Ambientalista Brasileiro no Cerrado. Goiânia, GO. 2004.

Ferreira, M. E., Ferreira Jr., L. G., Peccinini, A. A., Huete, A. R. Análise Comparativa dos Produtos MODIS Ecologia para o Monitoramento Biofísico Ambiental do Bioma Cerrado. Revista Brasileira de Geofísica, 24, 251-260. 2006a.

Ferreira, M. E., Ferreira Jr., L. G., Ferreira, N. C. Cobertura vegetal remanescente em Goiás: distribuição, viabilidade ecológica e monitoramento. In L. G. Ferreira (Ed.), Conservação da Biodiversidade e Sustentabilidade Ambiental em Goiás: Prioridades, Estratégias e Perspectivas (pp. 148-164). Goiânia, GO: Universidade Federal de Goiás/Agência Ambiental/Banco Mundial. (no prelo). 2006c.

Ferreira, N. C., Ferreira, L. G., Ferreira, M. E. Sistema Integrado de Alerta de Desmatamentos do Estado de Goiás - SIAD-GO. Revista Infogeo. Curitiba, PR. 2006b.

Ferreira, N. C., Ferreira Jr., L. G., Huete, A. R, Ferreira, M. E. An operational deforestation mapping system using MODIS data and spatial context analysis. International Journal of Remote Sensing 28, 47-62. 2007.

Gilpin, M. E., Hanski, I. Metapopulation Dynamics. Empirical end Theoretical Investigations. Cambrige Univ. press, Cambrige and New York. 1991. 
Mantovani, J.E., Pereira, A. Estimativa da integridade da cobertura vegetal de cerrado através de dados TM/Landsat. In Anais $9^{\circ}$ Simpósio Brasileiro de Sensoriamento Remoto Santos, SP: INPE. 1998.

Myers, N., Mittermeier, R.A., Mittermeier, C.G., da Fonseca, G.A.B. \& Kent, J. Biodiversity hotspots for conservation priorities. Nature 403, 853-858. 2000.

Nepstad, D., Klink, C. A., UHL, C., Vieira, I. C., Lefebebvre, P., Pedlwski, M., Matricardi, E., Negreiros, G., Brown, I. F., Amaral, E., Homma, A., Walker, R. Land use in Amazônia and the Cerrado of Brazil, 49 (pp. 73-86), São Paulo, SP: Ciência \& Cultura. 1997.

Novaes, P. da C., Lobo, F., Ferreira, M. E. Pobreza, Desenvolvimento e Conservação da Biodiversidade em Goiás. In L. G. Ferreira (Ed.), Conservação da Biodiversidade e Sustentabilidade Ambiental em Goiás: Prioridades, Estratégias e Perspectivas (pp. 110-132). Goiânia, GO: Universidade Federal de Goiás/Agência Ambiental/Banco Mundial. (no prelo). 2006.

Plummer, M. L., Mann, C. C. Are wildlife corridors the right path? Science 270, 1428-1430. 1995.

PNUD, IPEAD e Fundação João Pinheiro Atlas do Desenvolvimento Humano no Brasil. Brasília: PNUD [Software]. URL http://www.pnud.org.br/atlas/. 2002.

Ricklefs, E. E. The Economy of Nature: a Textbook in Basic Ecology. University of Pennsylvania: Chiron Press. 1996.

Sano, E. E., Barcellos, A. O., \& Bezerra, H. S. Assessing the spatial distribution of cultivated pastures in the Brazilian savanna. Pasturas Tropicales 22 (3), 2-15. 2002.

Sano, E. E., Dambrós, L. A., Oliveira, G. C., Brites, R. S. Padrões de cobertura de solos do Estado de Goiás. In L. G. Ferreira (Ed.), Conservação da Biodiversidade e Sustentabilidade Ambiental em Goiás: Prioridades, Estratégias e Perspectivas (pp. 76-93). Goiânia, GO: Universidade Federal de Goiás/Agência Ambiental/Banco Mundial. (no prelo). 2006.

SIEG. Sistema Estadual de Estatística e de Informações Geográficas de Goiás http://www.sieg.go.gov.br. 2006.

Viana, V. M. Biologia e manejo de fragmentos florestais. In Anais $6^{\circ}$ Congresso Florestal Brasileiro (pp. 113-8). Campos do Jordão, SP. 1990.

Flávia C. Ribeiro - Agrimensor (CEFET/1997) e Especialista em Geoprocessamento (FAG0/2007).

Cristiane da C. Vilela - Agrônoma e Especialista em Geoprocessamento e Georeferenciamento (FAGO/2007).

Fátima M. Kowata - Engenheira Civil (FACEA/1996), Especialista em Engenharia de Segurança do Trabalho (UFG/1997) e Especialista em Geoprocessamento (FAG0/2007).

Manuel E. Ferreira - Geógrafo (UnB/2000), Mestre em Processamento de Dados em Geologia e Análise Ambiental (UnB/2003) e Doutorando em Ciências Ambientais (UFG). 


\title{
Territórios e territorialidades urbanas em Goiânia: as tribos dos moto clubes
}

\author{
Territories and urban territorialities in Goiania: the tribes of the motorcycle clubs \\ Maria Elisabeth Alves Mesquita - IESA/UFG \\ geoelisabeth@gmail.com \\ Carlos Eduardo Santos Maia - IESA/UFG \\ carlmaia@uol.com.br
}

\begin{abstract}
Resumo
0 intuito deste trabalho é analisar as tribos urbanas, fenômenos contemporâneos, a partir das categorias território e territorialidade. Na tentativa de ampliar a visão sobre tal assunto, de inegável importância na atualidade, busca-se demonstrar como estas se organizam espacialmente e como se dá a sua dinâmica organizacional e inter-relação com o espaço citadino, tomando-se o exemplo dos moto clubes da cidade de Goiânia - GO. Acerca deste caso específico, investigaremos sobre os modos como os membros dos moto clubes goianienses se relacionam com as atividades de comércio e lazer da cidade mas, ao mesmo tempo, criam fronteiras em espaços sociais tidos como públicos, controlando o seu acesso. Assim, notar-se-ão territórios que são firmados em códigos simbólicos, comportamentais e identitários de cada tribo no seu "pedaço".
\end{abstract}

Palavras-chave: território, territorialidade urbana, tribos urbanas e moto clubes

\begin{abstract}
The intention of this work is to analyze the urban tribes, phenomena contemporaries, from the categories territory and territoriality. In the attempt to extend the vision on such subject, of undeniable importance in the present time, one searchs to demonstrate as these if they organize space and as if it gives to its organizacional dynamics and interrelation with the space city dweller, being overcome the example of the motorcycles clubs of the city of Goiânia - GO. Concerning this in case that specific, we will invest on the ways as the members of the motion goianienses clubs if they relate with the activities of commerce and leisure of the city but, at the same time, they create borders in had social spaces as public, controlling its access. Thus, territories that are firmed in symbolic codes, mannering and identitários will be noticed of each tribe in its "piece".
\end{abstract}

Key-words: territory, urban territoriality, urban tribes e motorcycle clubs

\begin{tabular}{|l|c|c|c|c|c|c|}
\hline Boletim Goiano de Geografia & Goiânia - Goiás - Brasil & v. 27 & n. 3 & p. 125-142 & jul. / dez. & 2007 \\
\hline
\end{tabular}





\section{Ligando os motores}

Nesta pesquisa, busca-se contribuir com uma possível interpretação para determinados aspectos relativos à espacialidade dos moto clubes da cidade de Goiânia. Moto clubes são organizações formadas, em sua maioria, por homens que possuem como bem comum a motocicleta. Afora o mero sentido de locomoção, esses motociclistas cultivam um ideal de liberdade e aventura que é proporcionado pelo veículo, costumeiramente materializado em longas viagens, previamente agendadas, chegando a ultrapassar as fronteiras brasileiras.

Os membros de moto clubes que, por questões de trabalho, não fazem essas viagens de longos percursos podem ser vistos nos encontros de motociclistas, nas sedes das entidades, nos moto bares e nas comemorações festivas (como aniversários) e eventos que acontecem durante todo o ano em Goiânia. Essas organizações são registradas em cartório, possuem estatuto e características diferenciadas entre si, de modo que, atualmente, têm-se contabilizado trinta e nove moto clubes em Goiânia, mas já existiram sessenta e dois.

Ressalte-se que, atualmente, o maior diálogo entre as ciências e a complexidade da dinâmica social clama por múltiplos olhares, estando a geografia atenta a esses gritos com enfoques plurais. Desse modo, nas páginas seguintes, questiona-se o fenômeno das tribos urbanas com um discurso transdisciplinar, mas costurado pelos conceitos de território e territorialidade. Toma-se a cidade de Goiana enquanto recorte espacial, pois aí se constituem, como noutras metrópoles, apesar dos rótulos de cidade country, capital sertaneja ou ainda da qualificação idílica de cidade das flores.

Perseguindo nosso objetivo, tomaremos, inicialmente, o caminho do debate teórico sobre o tribalismo contemporâneo para, a seguir, trafegarmos pelos movimentos de contracultura e tribos urbanas com vistas a desbravaremos os pedaços territorializados pelos motoclubes.

\section{Com o pé na estrada: do individualismo para o tribalismo contemporâneo}

O conceito de tribo tem seu domínio original na etnologia, sendo utilizado para definir uma forma de organização da sociedade, especialmente as indígenas, pela antropologia. Para Magnani (1992), pode-se dizer que tribo constitui uma forma de organização mais ampla, que vai além das divisões de clã ou linhagem, de um lado, e da aldeia, de outro. Trata-se de um pacto 
que aciona lealdades, que extrapola os particularismos de grupos domésticos e locais. Porém, o tribalismo aqui tratado possui outra conotação e se manifesta em espaços diferentes destes comentados.

Em se tratando de tribalismo no mundo contemporâneo e de novos modos de organização social, faz-se imprescindível o seguinte recorte espaço-temporal, a fim de decifrar em quais sociedades eclodiram esse fenômeno e quando: o urbano, em especial as cidades industriais ou centros de gestão financeira, de porte médio e grande, que hoje são chamadas de metrópoles nacionais e mundiais. "A grande metrópole contemporânea é, portanto, a expressão aguda e nítida desse modo de vida, o lócus, por excelência, das realizações e traços mais característicos desse novo tipo de sociedade" (VELHO, 1987, p. 17).

Mas o tribalismo nos faz pensar também em sua antítese: o individualismo. Em termos antropológicos, individualismo "é qualquer cultura onde o indivíduo tem um valor superior ao grupo, o termo individualismo aqui não tem uma conotação moral, no sentido em que usamos normalmente, como sinônimo de egoísmo" (CALIGARIS, 2003, p.3). Ao fazer um resgate histórico do individualismo, Maffesoli (2004) afirma que o período de reforma religiosa proposta por Lutero e Calvino foi essencial para a propagação deste ideário, introduzindo naquela época a noção de livre-arbítrio e a expressão de uma relação individual que um "eu" iria estabelecer com uma alteridade absoluta. Esta noção foi igualmente constatada na Revolução Francesa e no código napoleônico, onde se postula que a partir do indivíduo relacional é estabelecido um contrato social. Outra expressão que atesta essas concepções iniciais do individualismo é a autonomia ou individuo autônomo, ambas presentes em Descartes, na reforma e no iluminismo. Maffesoli observa que a idéia do eu sou a minha própria lei foi o pivô da modernidade, enfatizando essa concepção do indivíduo que dá a sua lei a si mesmo e que, em seguida, pode se associar a outros indivíduos autônomos para fazer a história. A partir daí, se constrói o contrato social. No Brasil, um caso exemplar de exaltação deste indivíduo foi consignado na lei de Gerson, nos anos setenta, amplamente divulgada na mídia, que preconizava que o importante é fazer a sua própria lei e tirar vantagem em tudo. $\mathrm{O}$ individualismo, então, é uma expressão social específica da modernidade.

Para Velho (1987), não existem projetos individuais puros, ou seja, sem referência, isto quer dizer que o individualismo não é um fenômeno puramente interno, subjetivo. Formula-se e é elaborado dentro de um campo de possibilidades, circunscrito historicamente e culturalmente, tanto em 
termos da própria noção de indivíduo como dos temas, prioridades e paradigmas culturais existentes. Nessa perspectiva, quanto mais exposto estiver o sujeito a experiências diversificadas, quanto mais tiver de dar conta do ethos e visões de mundo contrastantes, quanto menos fechada for sua rede de relação cotidiana, mais marcada será a sua autopercepção de individualidade singular. Há que se considerar que se está mais sujeito a isso nas grandes cidades contemporâneas do que em sociedades de pequena escala em virtude das possíveis invasões de seus mundos e das irrupções e crises ocasionadas pela proximidade física e social com outros estilos de vida e definições de realidade.

Cardoza (2003) complementa, observando a relação entre um sujeito que não tem mais domínio sobre as limitações de si e o sistema coletivo a que ele se integra, o qual lhe envolve a ponto de tornar-lhe inconsciente de sua própria atuação social. A autora retoma a teoria psicanalítica do inconsciente do século XIX, que causou uma onda de racionalização no homem, dizendo que o homem não poderia ser conhecedor e senhor de suas atribuições, pois, como parte pertencente de seu psiquismo, estava um inconsciente, com caracterizações tão primitivas e tão próprias que nem mesmo este homem antropocêntrico poderia tomar-lhe as rédeas.

Tal como Velho (1987) que trata da inexistência de projetos individuais, Maffesoli recorre a este primado para tratar do tribalismo. O tribalismo não é um fenômeno específico, mas uma metáfora da pós-modernidade, em que as grandes bases sólidas de organização social, as instituições como família, religião e estado nação estão saturadas, ou mesmo, como diz Maffesoli, são "porosas". Tem-se a impressão de que se percebeu que as idéias não eram mais autônomas, pois foram criadas a partir de um coletivo, e esse coletivo está sendo questionado. A humanidade então vive um "período empático", em que predomina a diferenciação e o perder-se em um "sujeito coletivo". O autor comenta que o tribalismo, chamado também por ele de neotribalismo, deve ser tomado como um novo paradigma que substitui o do individualismo na compreensão da sociedade contemporânea, e continua: "Assistimos agora à passagem da identidade para as identificações múltiplas. É essa passagem que me parece fundar o nascimento de formas tribais de existência (...) Aqui, onde nós deveríamos pensar em nós mesmos, vemos constituir-se pequenas entidades sectárias, fanáticas, opondo-se umas às outras (MAFFESOLI , 2004, p.28)”.

Cardoza (2003) atesta que, desta forma, a pós-modernidade caracteriza-se por trazer consigo todas as mudanças culturais e sociais resultantes 
do triunfo do capitalismo sobre o socialismo real e do declínio de um individualismo hegemônico; da modernidade fundada na máxima da razão e nos princípios iluministas, o que é compartilhado por Maffesoli. Isto vem alterar a percepção da realidade do indivíduo, que é obrigado a redefinir suas práticas cotidianas e estar exposto às diferenciações de experiências a serem vivenciadas; acarretando o declínio das tradições e a acelerada pluralização de grupos primários - a chamada dessocialização causada pela cultura de massa, que resulta na constituição de um novo enfoque às subjetividades, promovendo novas noções de hábitos e valores.

Dando continuidade a essa explanação da saturação das instituições e da perda de evidências e valores, que tentam explicar a queda do individualismo e fixação do tribalismo, retomamos a Caligaris (2003) que atribui essa perda ao princípio do capitalismo de exaltar a predominância de sujeitos não definidos por suas origens, seus grupos, seus laços e suas histórias, tornando-se puros agentes econômicos, produtores e consumidores. Por um lado, nossa subjetividade, notavelmente rarefeita, continua assim porque tudo o que nos definia de maneira concreta (a origem, o sangue, a casta, o privilégio, as obrigações da história) não nos define mais. As tradições que regravam nossa vida, que fundavam as divisões em grupos de poder, são atacadas e recusadas. Paralelamente, espera-se que em nós mesmos enquanto indivíduos seja possível encontrar novos fundamentos para a convivência social, para não sermos regrados pelas mesmas tradições e cânones que então negamos.

Para Caligaris (2003), essa autodefinição de indivíduo é bastante abstrata, pois parte da premissa deste ser definido pelos grupos de pertencimento, chegando-se à busca da autenticidade, termo que se torna crucial, sobretudo nos últimos 200 anos. O autor exalta a idéia de a humanidade ter criado uma paixão pela autenticidade, ou seja, por aquele lugar onde seríamos únicos, diferentes e completamente nós mesmos.

Contudo, agora é visto que o capitalismo descobriu que o maior estímulo ao consumo é a nossa procura de autenticidade, a nossa consideração dos outros, pois só assim pode-se afirmar a autenticidade, ou seja, dependese do olhar dos outros. A diferença em nossa vida social é instituída pelo reconhecimento que vem dos outros. Aqui está o grande dilema das sociedades ocidentais contemporâneas: o sonho de uma sociedade de indivíduos e a necessidade de fragmentação social, para justamente cada um poder assim ser reconhecido pelo que ele é. Infere-se que estaríamos caminhando em direção à persona e à multiplicidade de papéis e máscaras a pessoa só existe 
em termos do papel ou máscara usada em dado momento ou situação, como chama atenção Maffesoli (2004).

Nessa perspectiva de existir como sujeito identitário em função de um grupo social, vimos que, em especial, o homem cuja vida é predominantemente urbana, está mais sujeito à absorver e criar novas identidades, ou, como afirma Amaral "é um homem multifacetado" (1992, p. 46). Simmel, de modo complementar, exara: "Sua noção de pessoa é constituída pela soma dos efeitos que dela emana temporal e espacialmente” (1987, p.21). Mesmo que as bases econômicas e forças globalizadoras nos transmitam a idéia de um ser uniformizado, universalista, essa idéia é aparente, "se a cidade atual parece apresentar uma sociedade sem estilo é justamente porque sua feição é a somatória dos estilos dos grupos que vivem nela" (1992, p. 35).

Somando outras a essas explicações sobre o fenômeno tribal, temos Takeuti (2004), que evidencia esse acontecimento na sociedade juvenil, mas traz observações pertinentes para tal escolha de viver em grupo em termos gerais, ou seja, nas demais faixas etárias. Takeuti atribui o tribalismo à ineficácia simbólica existente na sociedade. Essa sugestão não vem discordar dos autores citados anteriormente, mas sim complementar a idéia sobre a perda de evidências. Nota-se que, a precariedade simbólica consistente, em que se disponibilizam os modelos identitários, é fruto da valorização radicalizada da dimensão econômica e sua prevalência enquanto significação imaginária social causadora da aniquilação de valores que poderiam trazer outros sentidos de vida aos indivíduos.

Não se pode relegar o limite do vazio, fato notório nas sociedades industrializadas, o que para Bertaux (1988) revela-se como um estar em todos os lugares e ao mesmo tempo não se estar em parte alguma, no sentido efetivo de pertença. O indivíduo, desse modo, liberado de toda amarra, mas também desprovido de toda a individualidade, está pronto para se juntar a qualquer grupo, pronto a endossar a identidade que se queira bem lhe propor, ou seja, tudo menos o vazio.

Através de Caligaris (2003), Maffesoli (1944) (2004), Takeuti (2004), Velho (1987), Cardoza (2003) e Bertaux (1988) tem-se a caracterização da situação pós-moderna, na qual o tribal surge como uma espécie de compensação diante de uma sociedade cujos laços e coesão social são frágeis. Reencantamento pelo mundo é o termo usado por Quaresma (2006) para definir essa situação, ou seja, o fenômeno neotribal traz uma possibilidade de reencantamento, tendo como cimento principal uma emoção ou sensibilidade vivida em comum. O período pós-moderno demonstra que os homens estariam adotando um ponto de vista mais emotivo em relação ao mundo. 
Max Weber já fazia observações sobre esses laços quando se referia às comunidades afetivas ou emocionais, termo também utilizado por Mafessoli (2004) em relação ao homo estheticus, "base do tribalismo", na visão do autor, já que se constitui nas "emoções compartilhadas".

Para Quaresma (2006), essa proposta de Maffesoli traz mesmo um novo paradigma de compreensão da sociedade contemporânea, que está baseado na necessidade de solidariedade e de proteção característicos do conjunto social. Desta forma, a metáfora tribo dará conta do processo de desindividualização e da valorização do papel que cada pessoa (persona) é chamada a representar dentro do grupo.

Dentre os diversos comportamentos sociais nascidos nesse momento, o de desencantamento pelo mundo sobressai principalmente entre os jovens, que deram origem à composição de tribos urbanas. Embora não se afirme ainda que os motociclistas de moto clubes são jovens, ou mesmo grupos juvenis, já foi percebido que o seu surgimento é uma resposta a esta sociedade que os deixou de fora. Também se reconhece que esses grupos não tencionam necessariamente o questionamento da ordem social, mas não deixam de ser uma reação à dificuldade de "entrar" neste modo de vida, ou seja, produzem uma resposta à condição social. Resgatemos, para esclarecer melhor isto, o que foi caracterizado como Movimentos de Contracultura.

Antes Sonhava, Hoje não Durmo: percorrendo os movimentos de contracultura e tribos urbanas

A contracultura foi um movimento que teve como endereço de origem os Estados Unidos e, como data característica, o pós-guerra, final da década de 40. Entendamos a situação estadonidense naquele contexto para que compreendamos melhor o porquê de certas circunstâncias sociais, econômicas e culturais terem propiciado o nascimento desse movimento naquela sociedade.

Marcuse (1982) observa que, existiu, imediatamente, no pós-guerra, uma ausência de agentes de transformação social na sociedade norte americana tecnologicamente desenvolvida, o que demonstrava um certo grau de alienação social. Criou-se a falsa idéia de que nada faltava ao homem que possuía um emprego, dinheiro para as necessidades imediatas, para bens de consumo duráveis e não duráveis, e ainda podia escolher seus futuros representantes, gerando a sensação de autonomia e liberdade. Foi naquela nova sociedade, de indivíduos reprimidos e submissos a uma cultura massificada, em que prevalecia a ilusão de progresso e liberdade, que vieram à tona protestos contra a própria pátria e seus falsos pais, falsos professores e falsos 
heróis; movimentos que foram minados pela sua imaturidade, apolitização e sugados pelos meios de comunicação de massa.

Retornando-se ao início do povoamento dos Estados Unidos, percebe-se o enraizamento deste ideal de liberdade naquela terra. Vindos principalmente de países europeus, os povoadores fugiam dos tabus culturais e morais, dos padrões judaico-cristãos, das tradições, dos preconceitos e das velhas formas de instituições sociais, como afirma Almeida (1996). Esse imaginário de liberdade foi inculcado entre os jovens.

Após a Segunda Guerra Mundial e o intenso desenvolvimento tecnológico norte americano, vê-se a perda daqueles antigos ideais de liberdade e a aridez afetual e emocional citada anteriormente. Faz-se importante afirmar que essa aridez não é ocasionada especificamente pela consolidação do capitalismo, como se as mudanças econômicas fossem as únicas responsáveis pelas mudanças na organização social. Almeida (1996) diz que a contracultura não foi propriamente um movimento anti-capitalista. Ao mesmo tempo, manifestou-se contra a cultura estabelecida, daí o nome contracultura, plantando novos ideais de viver em relação à família, ao casamento, às relações sexuais, com o corpo e com a natureza.

Os jovens desse momento gozavam de tempo livre e da não necessidade de trabalhar, fala-se aqui dos jovens de classe média, favorecidos por uma intensa aquisição de bens materiais e vivendo em uma materialidade até então desconhecida. Envolvidos na propagação da guerra fria e ainda questionando o horror da guerra, tais jovens recorrem àquele velho ideal de liberdade e começam a questionar a cultura norte americana vigente. Porém, esse questionar foi impulsionado por uma educação liberal, que estimulava a capacidade de expressão. Com isso, os jovens passaram a ser mais críticos e contestadores, exigindo soluções para os problemas que os rodeavam, sendo esta ação uma resposta ao momento em que viviam, como atesta Santos:

Não é estranho que a contracultura tenha surgido no seio da sociedade norte americana, pois é justamente aí que a tecnocrata-sociedade, gerenciada por especialistas técnicos e seus modelos científicos - atingiu o auge de seu desenvolvimento, obrigando o jovem a adaptar-se rapidamente a uma realidade mecânica, árida e desprovida de qualquer impulso criativo. Com isso, a contracultura se tornou a forma de expressão mais importante dessa parcela de jovens que procuravam "cair fora" - drop out - dos padrões estabelecidos por essa sociedade, para construir um mundo alternativo com uma "cultura” própria (2005, p.63-64). 
Rebeldes sem causa foi uma expressão muito utilizada para definir aqueles jovens norte americanos, que, através do cinema, foram propagados. "Os problemas dos jovens norte americanos passavam a ser também os problemas de jovens de outros países" (Canhête, 2004, p. 49). O resultado disso foi a criação de uma postura de confronto com o mundo adulto, surgindo um novo estilo de organização social. Com os heróis do cinema, vieram as gangs, que se contrapunham inteiramente aos modos de vida preconcebidos pelo mundo dos adultos (Canhête, 2004). Contudo, é necessário pensar em gang como uma reunião de jovens da classe média, imigrantes, com ideais de mudança, e não no sentido atual dado ao termo gang relacionado com violência, periferia e jovens pobres.

Percebia-se, naquela época, uma exaltação ao ser jovem e à conquista de um espaço na sociedade pela juventude, iniciando-se a formação dos primeiros territórios juvenis, já que, de um contexto social em que se "saltava a adolescência”, passou-se a outro no qual a adolescência era a idade favorita. Deseja-se chegar a ela cedo e nela permanecer por muito tempo, como menciona Abramo (1994), que ainda salienta o aumento da disponibilidade e da procura por diversão e por elementos diferenciados de consumo. Isso provocou rápida resposta por parte da indústria, do comércio e da publicidade, que passaram a produzir bens específicos para esse público, alimentando o espraiamento dos novos hábitos, como a locomoção por motocicleta. Morin (1986) também percebe aquela juventude como resposta ao modelo da sociedade pois, favorecida pela "relativa autonomia monetária" (conseguida com mesadas ou empregos), acede a bens e formas de lazer e torna-se contestadora e exigente de maiores liberdades.

Roszac (1972) vê o movimento de contracultura como uma oposição juvenil a essa sociedade tecnocrática, que atinge o ápice de sua integração organizacional por meio de imperativos incontestáveis como a procura de eficiência e segurança, combinados com o desejo de racionalização.

Os ideais, pensamentos e manifestações juvenis, vindos do pós-guerra, nas sociedades mais industrializadas, formaram então o Movimento de Contracultura, que foi assumido por grandes grupos que tomam proporções internacionais, como os Hippies. E como se inserem nisso as tribos urbanas? Nos movimentos de contracultura, surgiram grupos específicos denominados de tribos urbanas por autores como Zalduendo (2000), Almeida (1996), Canhête (2004), Chies (2007), Borges e Covre (2007) e Coutinho (2007).

Os grupos vindos dos movimentos de contracultura, e que atualmente são chamados de tribos urbanas, são manifestações passageiras, ou 
seja, englobam a faixa de transição para a vida adulta e esta, quando chega, força o pertencente a abandonar sua tribo, como confirma Coutinho: "a transitoriariedade e o imediatismo se congregam numa certa apologia do presente vivido na tribo, não há projetos futuros ou preocupações com o destino da tribo" $(2007,04)$. São escassos os citadinos que permanecem vivendo em tribos urbanas, neste sentido, até a "velhice", e, quando isso acontece, como é o exemplo do movimento Hippie, eles criam vivências grupais fechadas e à margem do sistema, sem grandes configurações coletivas que permitam sua visualização enquanto movimentos culturais, como as comunidades alternativas.

Acerca dos moto clubes, a partir dessas observações, é nítido que eles surgiram em meio ao movimento de contracultura nos Estados Unidos e, atualmente, são incluídos nas tribos urbanas. A seguir será apresentado um breve histórico do surgimento desses grupos, assim como uma caracterização de seus territórios e territorialidades existentes na cidade de Goiânia.

\section{A Distância Mostra Como é Bom Estarmos Juntos: tribos de moto clubes goianienses}

Em meados de 1940, surgem os primeiros Moto Clubes do mundo, exatamente nos Estados Unidos, estando dentro dos ideais que posteriormente foram chamados de contracultura. Eram formados, naquele momento, por homens jovens, mas com idade e condições financeiras para possuir uma motocicleta e dedicare-se a viagens pelas rodovias do país, sendo conhecidos nas décadas seguintes como gangues de motociclistas. Outra origem foi a dos ex-combatentes que decidiram igualmente viajar de motocicletas na tentativa de esquecer os dias vividos em guerra (2004). Percebe-se, com isso, que o veículo apresentava outro sentido, ultrapassando o de simples locomoção de pessoas, posto que associava-se também a um novo modo de vida, um novo grupo urbano, ou uma nova tribo urbana.

Os primeiros M.C. foram os Hell's Angel, Diablos, Presidents, Road Rats, Nightriders, Question Marks e Satan's Slaves (Thompson, 2004). Origina-se aí também o mito do motociclista anti-social e da motocicleta como instrumento de liberdade, protesto e irreverência. As motos vindas das duas grandes guerras e modificadas por esses motociclistas foram batizadas de Choppers, termo britânico que possui o significado de cortada, modificada. Isto consiste em aproveitar o quadro e/ou o motor da moto original, sendo 
que os demais acessórios vão sendo moldados pela arte e criatividade. O que surge nesse momento é o processo conhecido na atualidade como personalização ou customização de motocicletas. Enquanto as indústrias automobilísticas produziam automóveis confortáveis e motocicletas tecnologicamente modernas para locomoção de pessoas, esportes e longas viagens, certos motociclistas preferiam construir as suas próprias e diferenciadas motocicletas.

Com o auxílio da indústria do cinema, principalmente de Hollywood, este modo de vida (viajar em grupos de motocicleta) se propagou pelo mundo através de filmes, seriados, documentários e desenhos animados como Jaspion, Carangos e Motocas, Jiban, O vigilante rodoviário, The wild one, Rebel without a cause, Easy Rider, East of éden, Ruas de fogo, Amor a toda velocidade, Selvagem da motocicleta e Selvagens da noite.

No que se refere ao Brasil, Zardini (2007) informa que, durante a segunda guerra mundial, o país enviava alimentos para os combatentes em troca de motocicletas usadas. Fonseca (2001) complementa que, em meados de 1940, foram importadas motocicletas vindas de fábricas da Itália, Alemanha, Inglaterra e Estados Unidos para fins militares, também sendo posteriormente vendidas para uso particular e para competições. Paralelamente, importou-se o costume europeu de expor os veículos militares, em especial as motocicletas, nos festejos e desfiles cívicos.

Em Goiânia, Fonseca (2001) comenta que as primeiras motocicletas chegaram em 1942, também importadas para fins militares, sendo isto incentivado por Pedro Ludovico Teixeira (primeiro prefeito de Goiânia), que possuía fascínio por este veículo. Em 5 de julho de 1942 as motocicletas entraram nas comemorações cívicas do batismo cultural da cidade, sendo expostas nos desfiles e participando de competições.

Em 1955, surge o Moto Clube de Goiânia, com 146 sócios, e também a Federação Goiana de Motociclismo, organizações que incentivaram as competições na cidade e a construção do Autódromo Internacional de Goiânia, em 1974. Porém, ressalte-se que essas organizações nada pareciam com os atuais moto clubes existentes em Goiânia e tampouco com os gestados em solo americanos.

O primeiro moto clube de Goiânia foi o Vikings, fundado em 1986 por colecionadores de motocicletas antigas e amantes do modelo chopper. Os seus membros participaram de encontros de colecionadores pelo país e promoveram esse tipo de encontro em Goiânia também. Com esses eventos, conheceram moto clubes brasileiros com ideais e formas de organização próximas às de contracultura dos Estados Unidos, foram eles os Sarracenos, 
Balaios, Carcarás e Águias de Aço. A partir desse contato, os Vikings modificaram a estrutura de apenas colecionadores de motocicletas para se tornarem de fato moto clube. Como isso, surgiram conflitos internos no grupo e alguns membros dissidentes fundaram o Chopper, o Papa-Léguas e o Alcatéia, todos em 1994 e existentes até hoje. Juntamente com esses moto clubes, surgiram oficinas especializadas em personalização e customização, além de espaços específicos para encontros e comércio especializado em acessórios; assim como a cidade se abre para que moto clubes de outros estados fundem facções1 em Goiânia.

Atualmente, são trinta e nove M.C.s com características diferenciadas entre si. Existem os que seguem ideais daqueles gestados em solo americano, os que são compostos por elos familiares ou de amizades, além dos maçônicos, filantrópicos, religiosos (evangélicos), de distinção sexual (mulheres) e que exigem marca, modelo ou cilindrada específica da motocicleta.

Nessa re-significação do uso da motocicleta e dos moto clubes, Teixeira (2006) divide essas entidades segundo as formas de organização em Moto associações, Moto clubes familiares e Moto clubes tradicionais. As Moto associações se identificam com aquelas organizações de 1955 em Goiânia (Moto Clube de Goiânia e Federação Goiana de Motociclismo, que envolve os esportes); os familiares são grupos de amigos, pais e filhos que viajam juntos; já os tradicionais "tentam” preservar o ideal originário dos Estados Unidos e têm regras mais severas para pertencimento ao grupo.

Para apreender melhor a razão de ser desses grupos e sua apropriação do espaço urbano, utilizam-se aqui os conceitos de território e territorialidade. Sobre território, é nítido que as tribos urbanas são formadoras de territórios diferenciados na cidade. A requisição, a posse, ou o controle espacial, mesmo que temporário, expressam relações de poder intimamente ligadas às maneiras de agir sobre os outros, diferenciando quem controla e quem é controlado em um dado terreno. De outro modo, conforme observa Sack (1986), o território é formado em determinado espaço apropriado, no sentido de afetar, influenciar e impor diferentes tipos de acesso às pessoas e aos recursos.

As tribos urbanas mencionadas se expõem, em especial, no cenário noturno, e delimitam os seus territórios com a "simples" presença corporal. Naquele tempo de estadia, o seu território é fixo e diferenciado, chegando a fazer os outros mudarem a direção do caminhar para não invadi-lo. Porém, mesmo na ausência corporal, os territórios podem delimitar-se através de suas representações simbólicas, o que se considera como território invisível. 
Propõe-se então que existem territórios fixos, eventuais, visíveis e invisíveis, não se podendo relegar o fato de que há territórios em diversas escalas, podendo se estender desde um país ou bloco continental (como no caso do moto clube Hell's Angels que é internacional e o que contém mais filiados, ou como o Chopper que só existe e contém três membros) até uma quadra de bairro, ou uma mesa de bar (como acontece nos encontros esporádicos).

Na formação de territórios são tomadas iniciativas individuais ou grupais (estratégias territoriais) para delimitação e manutenção. Essas estratégias são consideradas aqui como territorialidades. De acordo com Machado (1997) a territorialidade corresponde às ações desenvolvidas por vários agentes sociais em uma determinada área geográfica e em um dado momento histórico. As ações são produzidas pelas diferentes relações estabelecidas entre os agentes em um específico recorte espaço-temporal.

Olhando-se para os moto clubes a partir desses dois conceitos (território e territolialidade), tribo urbana torna-se uma metáfora para entendê-los como associações existentes na cidade que trazem consigo inúmeras cargas comportamentais e simbólicas para marcarem a sua territorialidade no espaço urbano, muitas vezes com a "simples" presença corporal de um membro usando o colete, ou mesmo pela presença de seus símbolos identitários, motocicletas diferenciadas, faixas de segurança, bandeira do moto clube, ou cones. Foi feito um levantamento dos territórios fixos e eventuais, abrangendo o período já mencionado, e concluiu-se, que na década de 8,0 os moto clubes utilizavam espaços públicos e comerciais para se reunirem e, posteriormente, surgiram as sedes e espaços públicos cedidos pela prefeitura para promoção dos encontros, notando-se, assim, o aumento desses territórios pela cidade (Figura 1).

Esses territórios apresentados demonstram diferenças em escalas espaço-temporais, e, principalmente, na forma de manutenção, portanto, o que deve ser explicitado são as rivalidades e conflitos na ultrapassagem dessas fronteiras físicas ou invisíveis.

No moto clube, existe hierarquia de organização composta por presidente, os membros mais velhos, com o colete completo, e os membros mais novos, com o colete faltando o brasão e geralmente constando apenas com o nome do moto clube. Estes geralmente são os guardas das motocicletas em eventos, para que não roubem, não toquem, ou mesmo não tirem fotografias. Os moto clubes com sede, restringem a entrada apenas a convidados e com datas e horários específicos. No caso dos moto bares, existem aqueles cujo proprietário é membro de um moto clube, mas isto não é regra. Em sendo 
proprietário, a freqüência, no que diz respeito a integrantes de moto clubes, é exclusiva de pares, ou brothers.

Quadro 1. Territórios de moto clubes na cidade de Goiânia - Década de 80 aos anos 2000 .

\begin{tabular}{|c|c|c|}
\hline Década de 80 & Década de 90 & Anos 2000 \\
\hline $\begin{array}{l}\text { § Oficina e Residência - Antônio } \\
\text { Águia } \\
\text { § Residência Derosi } \\
\text { § Pizzaria Quadra } 100 \\
\text { § Automóvel Clube } \\
\text { § Residência Sr. Guerino } \\
\text { § Oficina - Adir } \\
\text { § Bar Circus } \\
\text { § Loja } 1000 \text { Yamaha } \\
\text { § Sede dos Vikings M.C2. } \\
\text { § Residência e oficina do Alcides } \\
\text { § Residência e Oficina do } \\
\text { Zardini } \\
\text { § Estacionamento do M.C. } \\
\text { Donalds }\end{array}$ & $\begin{array}{l}\text { § I Encontro Nacional de } \\
\text { Antigomobilismo } \\
\text { § II Encontro Nacional de } \\
\text { Antigomobilismo - Classic } \\
\text { Motor Show } \\
\text { § Zardini Super MotoShow - } \\
1994 \text { até } 2000 \\
\text { § Praça Universitária } \\
\text { § Bar Honk Tonk } \\
\text { § Avalon Boate } \\
\text { § Terceira Onda Boate } \\
\text { § Oficina e Residência - Antônio } \\
\text { Águia } \\
\text { § Gyn Moto Rock } \\
\text { § Oficina do Geraldo e Luizim } \\
\text { § Oficina Jabur } \\
\text { § Estacionamento do Girafas } \\
\text { § Sede dos Vikings } \\
\text { § Pit Dog - Dog Din } \\
\text { § Pit Dog - Afonsos Burguer } \\
\text { § Pit Dog - Jocasto } \\
\text { § Feira da Marreta } \\
\text { § Alveria Bar } \\
\text { § Shopping Bouganville } \\
\text { § Goiânia Shopping }\end{array}$ & $\begin{array}{l}\text { § Shopping Bouganville } \\
\text { § Goiânia Shopping } \\
\text { § Shopping Flamboyat } \\
\text { § Centro Cultural Oscar } \\
\text { Niemeyer } \\
\text { § Parque de Exposição } \\
\text { Agropecuária de Goiânia } \\
\text { § Rua c-30 } \\
\text { § Sede do QBU M.C. } \\
\text { § Sede do Hurricane M.C. } \\
\text { § Vai Toma no Kuka Bar } \\
\text { § Avenida Paranaíba } \\
\text { § Sede dos Muthantes M.C. } \\
\text { § Bar Muthantes M.C. } \\
\text { § Bar Dom Guina } \\
\text { § Sede do Alcatéia M.C. } \\
\text { § Bar Aro 16 } \\
\text { § Sede do Chopper M.C. } \\
\text { § Lote do Chopper M.C. } \\
\text { § Bar Taverna Vikings M.C. } \\
\text { § Posto da Rua 74 } \\
\text { § Goiânia Moto Show 2002 até } \\
\text { 2005 } \\
\text { § Bar Taba de Chiqueiro } \\
\text { § Posto T 10 } \\
\text { § Bar Torneadora Kaverna } \\
\text { § Oficina do Luizim } \\
\text { § Oficina do Geraldo } \\
\text { § Oficina do Robertão } \\
\text { § Nana Moto Elétrica } \\
\text { § Bráulio - Aerografia } \\
\text { § Jozé - Pintura } \\
\text { § Sede Prospect 81 M.C. } \\
\text { § Sede dos Forasteiros M.C. }\end{array}$ \\
\hline
\end{tabular}

Em locais públicos, como a praça da Avenida Paranaíba no centro de Goiânia, existe um encontro de moto clubes todas as quintas-feiras em período noturno. Desde 2001, quando foi cedido este espaço, cada moto clube 
tem o seu "pedaço" fixo. Então os novos moto clubes devem conversar com os mais antigos para poderem se encaixar na praça e aos poucos conquistarem o seu território.

Outra rivalidade nítida é estabelecida a partir do modelo e da cilindrada das motocicletas. As japonesas de alta velocidade são as jaspeiras, e as custom e choppers são chamadas de estradeiras. Em determinados encontros, é proibida a entrada de jaspeiros. Quanto à cilindrada, nos encontros só cobra-se a entrada de motocicletas abaixo de 250 cilindradas.

\section{No fim do caminho, o recomeço!}

Neste rápido texto, demonstrou-se como a inspiração em movimentos culturais influenciou o surgimento dos moto clubes e implicou na adoção de certos equipamentos definidores de territórios que, no caso específico de Goiânia, são moto bares, bares, praças, sedes, shows, eventos etc. alguns dos quais apropriados de modo flexível, servindo de local de passagem ou de encontros eventuais. Entretanto, não basta passar por esse lugar ou mesmo freqüentá-lo com alguma regularidade para ser do pedaço; é preciso estar situado (e ser reconhecido como tal) numa peculiar rede de relações e num sistema de hierarquia. Com isso, constroem-se códigos capazes de separar, ordenar e classificar, distinguindo os do dentro e os de fora do pedaço, bem como em que grau o brother pertence à galera dos moto clubes.

Finalizando, recorremos a Magnani (2006) que destaca que as grandes metrópoles contemporâneas não podem ser vistas simplesmente como cidades que cresceram demais e desordenadamente, potencializando fatores de desagregação. Elas também propiciaram a criação de novos padrões de troca e de espaços para a sociabilidade e para os rituais da vida pública, como é o caso dos moto clubes goianienses.

\section{Notas}

1 Quando um moto clube surge em um estado ou cidade e funda uma facção em um local diferente da sua origem.

2 Abreviatura nossa para moto clube 


\section{Referências}

ABRAMO, H. W. Cenas Juvenis. São Paulo: Página Aberta, 1994.

ALMEIDA, A. F. J. A contracultura ontem e hoje. Salvador: Ciclo de debates, 1996.

AMARAL, R. C. Povo santo, povo de festa, estudo antropológico do estilo de vida dos adeptos do candomblé paulista. São Paulo: USP, 1992.

BERTAUX, D. Individualismo e modernité. Revue Espace Temps, n. 37, Paris, 1988.

BORGES, P.; COVRE, R. A. Tribos Urbanas. Disponível em: http://www.nu-sol.org/libertarias/ libertarias-4/tribos_urbanas.htm. Acesso em 03 fev. 2007

CALIGARIS, C. Pluralismo, Multiculturalismo e Universalismo: Diferenças e Aproximações. Seminário Cultura e Tolerância, SESC Vila Mariana, nov. São Paulo, 2003.

CANHÊTE, D. L. Ecos do Subterrâneo: a questão da juventude e do movimento punk como subcultura - a década de 80. Goiânia: UFG, 2004.

CHIES, T. C. Novas formas de viver: Clubbers e Ravers. Os urbanistas. Disponível em: http:// www.aguaforte.com/antropologia/Clubbers3.html. Acesso em: 03 fev. 2007.

FONSECA, R. Motopop 2001. Goiânia: Gráfica O popular, 2001.

MACHADO, M. S. Geografia e Epistemologia: Um passeio pelos conceitos de Espaço, Território e Territorialidade. GEO UERJ, Rio de Janeiro, n.1, janeiro, 1997.

MAFFESOLI, M. O tempo das tribos. Rio de Janeiro: Forense Universitária, 2004.

MAGNANI, J. G. C. De perto e de dentro: notas para uma etnografia urbana. Revista Brasileira de Ciências Sociais, v.1, n.49, jun. 2002.

MARCUSE, H. A ideologia da Sociedade Industrial. Rio de Janeiro: Zahar, 1982.

MORIN, E. Cultura de Massas no Século XX: o espírito do tempo. vol.I. Neurose. Rio de Janeiro: Forense, 1969.

ROSZAK, T. A contracultura. Petrópolis: Vozes, 1972.

SACK, R. D. Human Territoriality: Its theory and history. Cambridge University, 1986.

SALEM, T. Filhos do milagre, Ciência Hoje, vol.5 nº 25, SBPC, 1986.

SANTOS, G. S. Movimentos Contraculturais: Mitos de uma revolta, poetas de uma revolução. Akrópolis, Umuarama, v.13, n.1, jan. 2005.

SIMMEL, G. A metrópole e a vida mental. In: VELHO, G. (Org.) O fenômeno urbano. Rio de Janeiro: Guanabara, 1987.

TAKEUTI, N. Subjetividades e vínculos sociais. In: SOUZA, I.M. Café Filosófico: filosofia, cultura, e subjetividade. Natal: EDUFRN, 2004.

TEIXEIRA, L. R. M.C.s: Parte I. Boletim Informativo Tribo do Cerrado MC. Goiânia, ano 3, 12 Ed. dez. 2005.

TEIXEIRA, L. R. M.C.s: Parte II. Boletim Informativo Tribo do Cerrado MC. Goiânia, ano 4, 12 Ed. jan. 2006. 
THOMPSON, H. S. Hell's Angels: Medo e delírio sobre duas rodas.Tradução Ludimila Hashimoto. São Paulo: Conrad, 2004.

VELHO, G. Individualismo e Cultura: Notas para uma antropologia da sociedade contemporânea, 4 ed. Rio de Janeiro:Zahar, 1997.

ZALUENDO, C. L. La pasión neotribal contemporânea. In: TROPEA, F. (Org.) Tribus Urbanas: El ânsia de identidad juvenil: Entre el culto a la imagen y la autoafirmación através da violência. Buenos Aires: Paidós, 2000.

Maria Elisabethe Alves Mesquita - Mestranda em geografia pelo IESA - UFG

Carlos Maia - Prof. Dr. do IESA - UFG

Recebido para publicação em outubro de 2007 Aceito pra publicação em novembro de 2007 



\title{
0 entorno do Distrito Federal: nota exploratório de um trabalho de campo
}

\author{
Marcelo Antunes \\ marceloantunesufg@yahoo.com.br \\ Marcelo de Mello \\ mellogto28@yahoo.com.br \\ Tadeu Alencar Arrais \\ tadeu.arrais@pq.cnpq.br
}

Pensar em um trabalho de campo, planejá-lo, não é uma tarefa fácil. Por menor que seja a dimensão do espaço e sua densidade histórica, é imprescindível planejá-lo, o que significa avaliar os recursos e o roteiro com disposição e abertura de espírito. No caso aqui relatado, a realidade contemplada solicitou uma grande preocupação com as formas de abordagem, com os procedimentos que viabilizariam uma interlocução inicial com um território que pode ser caracterizado como um dos mais complexos do cenário nacional. Cabe registrar que o trabalho de campo foi uma etapa de um Projeto financiado pelo $\mathrm{CNPq}^{1}$, que tem como um de seus objetivos principais oferecer subsídios para a compreensão do processo que veio a promover uma acentuada fragmentação no Entorno do Distrito Federal, bem como no seu espaço intra-urbano.

A partir dessas considerações, foram definidos, teoricamente, vetores de articulação e expansão da mancha urbana do Distrito Federal, tendo como referência os municípios goianos. De forma simples, esses vetores correspondem aos eixos rodoviários de maior fluxo. $\mathrm{O}$ vetor 01 corresponde à BR-070, que faz a ligação entre Águas Lindas e o DF. O vetor 02 é a BR-040, que dá acesso a Valparaíso de Goiás, Cidade Ocidental e Luziânia. Como vetor 03, consideramos a BR-020, que dá acesso aos municípios de Formosa e Planaltina de Goiás.

Cada um destes vetores tem como marca uma área de transição no encontro entre o território goiano e o território brasiliense. Entretanto, esta transição apresenta peculiaridades que diferenciam substancialmente cada vetor. ${ }^{2}$ Devemos destacar, ainda, que todos os vetores têm como elemento de convergência a rodoferroviária, situada em um lugar estratégico do Distrito Federal, no entroncamento do Eixo Monumental com o Eixo Rodoviário Norte/Sul. Assim, a transição de um vetor para o outro implicou em percorrer o espaço intra-urbano do Distrito Federal, o que, certamente, contribuiu para o melhor entendimento da dinâmica regional. 
Em se tratando do Vetor 01, podemos afirmar que as primeiras impressões surpreenderam até quem já tinha experimentado um contato anterior com este município. O processo de expansão urbana é marcado, fundamentalmente, pela horizontalidade, uma das principais características de Águas Lindas de Goiás.

É importante destacar que o acesso a Águas Lindas se inicia por meio da Estrada Parque Ceilândia, uma via duplicada - sendo que cada sentido desta estrada possui várias faixas - de acesso rápido que, devido à intensidade do fluxo de veículos nos horários de pico tem seu trânsito direcionado em um único sentido duas vezes durante o dia. No início da manhã, os veículos que saem de Taguatinga, Ceilândia, Águas Lindas, dentre outros, vão rumo ao Plano Piloto e, no final da tarde, percorrem o sentido contrário. Essa inversão de fluxo é a evidência mais clara do intenso movimento pendular desses municípios.

Mas podemos afirmar que as margens da Estrada Parque Ceilândia já anunciam, acintosamente, o desordenamento e a heterogeneidade da ocupação espacial que passou a ser uma das principais marcas do território em foco. Após um setor destinado ao armazenamento e distribuição de produtos inflamáveis, tem início uma série de edificações que contrastam com o ordenamento percebido nas áreas originalmente planejadas do DF. Nos primeiros quilômetros, esta situação é mais flagrante na margem esquerda da Estrutural, pois, à direita, encontram-se os trilhos da ferrovia. No transcurso desta Estrada, encontramos galpões com variadas estruturas e destinações, habitações em condições de precariedade extrema e casas suntuosas compartilhando uma mesma referência espacial, que é a Estrada Parque Ceilândia. Estas construções contrastantes muitas vezes são encontradas a poucos metros de distância uma da outra e no mesmo lado da Estrada. Ao avançarmos efetivamente os solos que ladeiam a BR-070, entramos em contato com Ceilândia. A horizontalidade também é uma marca dessa cidade satélite que atingiu, no ano de 2004, uma população de 332.455 habitantes (GDF, 2006), o que a torna a mais populosa do Distrito Federal.

Com certeza, é entre os quilômetros 12 e 13 da BR-070 que nos defrontamos com uma das materializações presentes neste território que mais deixam à tona a grave dimensão dos problemas existentes na Região do Entorno do DF. Neste trecho da rodovia, surge um emaranhado de barracos de tábua. Estes se encontram submersos num mar denso de poeira, que faz com que não consigamos avaliar a verdadeira dimensão desta formação. E à beira da rodovia, crianças de seis anos trazem, sob sua tutela, seus irmãos de quatro e três anos. Este aglomerado de meninos e meninas fica sob a nuvem 
de poeira à espera do transporte coletivo com o firme propósito de se encontrarem com a escola e com a merenda escolar, que, na maioria dos casos, é a única refeição do dia.

Chegando a Águas Lindas de Goiás, percorremos uma de suas principais vias e o que impressionou foi a dificuldade de os moradores identificarem a avenida em questão, o que revela, com certeza, um desencontro da população com o ambiente em que vivem. Essa situação reforça, também, o argumento de esta ser uma cidade pouco povoada durante o dia, já que partes significativas dos moradores constroem suas relações cotidianas no DF. Em outro ponto da cidade, nos deparamos com o lugar que, a princípio, permitiu que percebêssemos uma identidade entre os migrantes e a cidade. Foi um dia de domingo e este lugar é a feira. Lá, constatamos a presença marcante de maranhenses, paraenses, tocantinenses e baianos, seja entre os feirantes ou mesmo entre os consumidores. O comércio de farinha, a música e a culinária regional lembram, de certa forma, as férias locais do interior do nordeste e suas falas e trejeitos remetem, sem nenhuma dúvida, a suas terras natalinas. Não por acaso, de acordo com dados do censo demográfico de 2000, Águas Lindas de Goiás é o município goiano com maior porcentagem de nordestinos. Trata-se do mais nordestino município goiano e as provas disso estão na própria paisagem. São inúmeras as referências do comércio local aos estados de origem.

A BR-040 demarca o vetor 02, e é a ligação com o município matriz do Entorno do DF, ou seja, Luziânia, antigo arraial de Santa Luzia. De Luziânia, a partir do processo de fragmentação municipal, surgiram Valparaíso de Goiás, Cidade Ocidental e Novo Gama ${ }^{3}$. Com isso, Luziânia deixa de fazer limite territorial com o Distrito Federal. O primeiro município a ser cortado por quem sai do DF via BR-040 é Valparaíso de Goiás. Seu território envolve os dois lados da rodovia. Uma das marcas deste município é a diferença revelada pela paisagem quando se compara as duas margens do Vetor. A margem esquerda de quem segue rumo à região sudeste do Brasil, desde o início do processo de ocupação deste território, apresentou como características um padrão de ocupação espacial definido por conjuntos habitacionais - como no caso do Bairro Cidade Jardim - que manifestam formas geométricas definidas, em que as quadras e o arruamento obedecem à lógica que tradicionalmente tem referenciado a ocupação do solo urbano efetivada pelas obras construídas com financiamento público ${ }^{4}$. Já a margem direita da rodovia apresenta uma paisagem que denuncia a ausência desta lógica no padrão de ocupação deste solo em seu processo de apropriação pela expansão urbana. 
Na realidade, o que percebemos ao avaliar as formas materializadas neste lado da BR-040, em Bairros como Parque São Bernardo e Morada Nobre, é a existência de uma situação inversa: o improviso por parte da população na fixação neste solo e a ausência dos agentes que deveriam regular a ocupação. Este cenário salta aos olhos por meio das expressões materializadas de maneira aleatória, reveladas, por exemplo, pelo traçado irregular do arruamento e pelo desenho das quadras que contrastam com as estruturas simétricas presentes na outra margem. Sem falar, ainda, da diferença da infra-estrutura existente nos dois lados da rodovia.

Seguindo a rodovia, defrontamos com a Cidade Ocidental, o município mais povoado do Entorno do Distrito Federal. Sua densidade demográfica em 2000 era de 2061.64 habitantes por $\mathrm{km} 2$, enquanto que o segundo mais povoado, Santo Antônio do Descoberto, tinha 883.48 habitantes por KM2. Como Valparaíso de Goiás e Novo Gama, os embriões que deram origem a este município foram conjuntos habitacionais construídos com o intuito de reduzir os conflitos por moradia no interior do DF. Após o desmembramento, este município foi tomado por loteamentos que brotaram rapidamente, criando, também, realidades distintas, só que neste caso a BR-040 não é o divisor de realidades opostas. Em Cidade Ocidental, município com um território maior do que Valparaíso de Goiás, a expansão urbana se concentrou à margem esquerda da rodovia, mesmo porque a porção do território deste município situada à margem direita da BR-040 é muito menor do que a porção territorial do município apresentada pela outra margem.

Seguindo em frente, encontramos Luziânia; em outros tempos chamada de Santa Luzia e conhecida pela qualidade das marmeladas ali produzidas. Na atualidade, apresenta duas realidades: a primeira, produto de uma história que antecede a construção de Brasília, e que, logicamente, também foi afetada pela chegada na nova capital; mas que apresenta antigas edificações e um núcleo urbano bem semelhante ao de outras cidades do interior de Goiás. A segunda, por sua vez, remete às feições encontradas na maior parte dos municípios anteriormente descritos, principalmente no que se refere à precariedade das ações que promoveram a ocupação deste solo, tornado urbano sem o acompanhamento de políticas, ou mesmo iniciativas, que referenciassem o processo de apropriação deste território marcado pela presença de pasto e pela distância das condições mínimas que garantiriam o acesso desta população ao transporte, educação, saúde etc.

Para percorrer o Vetor 03, foi necessário cortar o DF no sentido Norte-Sul, tomando a direção da BR-020. O aumento do fluxo fez com que, na 
última década, uma série de obras fossem construídas para possibilitar o fluxo nesta rodovia. A última destas obras se encontra em frente à própria rodoferroviária. Na verdade, esta rodovia, que em um passado próximo ligava principalmente as cidades-satélites Sobradinho e Planaltina e os municípios goianos de Formosa e Planaltina de Goiás ao DF, passou a ter que responder à necessidade de deslocamento de uma série de outras áreas urbanizadas nos arredores destas cidades-satélites. Entre elas está desde condomínios fechados irregulares formados a partir de demanda por moradia da classe média-alta, até invasões com barracos de tábua à beira da estrada.

Deve ser destacado que mesmo antes de chegar a Sobradinho já existe uma série de áreas urbanizadas em um momento bem posterior à criação desta cidade-satélite. Nelas estão presentes edificações individuais com vários pavimentos, condomínios fechados horizontais e barracos improvisados caracterizados por uma precariedade em sua construção. Percorrendo a BR020, constatamos o avanço da expansão urbana no interior do DF. Nas duas margens da rodovia, o que se vê são manifestações concretas que comprovam a extrema complexidade que tem marcado as tentativas de gestão dos conflitos por moradia no interior desta Unidade Federativa.

O Vetor 03 é o responsável pela ligação do Distrito Federal com Planaltina de Goiás e Formosa. Na realidade, este Vetor é o responsável pelo acesso inicial ao município de Planaltina de Goiás, já que para chegar a este município goiano é necessário sair da BR-020 e seguir pela rodovia DF-128 nas proximidades do trevo de acesso a cidade-satélite de Planaltina. Apesar de Formosa e Planaltina de Goiás terem suas fronteiras na divisa do DF, não foram tão afetados pelo processo de expansão urbana do DF como os municípios vinculados aos outros dois eixos. Formosa, além de estar mais distante da capital federal, tem, entre a sede de seu município e a área de expansão do DF, o Parque Nacional das Águas Emendadas. Além disto, este município vive uma situação peculiar: ao mesmo tempo em que sofre a influência direta do DF é um dos que mais constituiu uma economia em que atividades e setores da economia revelam certa independência do DF, como é o caso da pecuária. Já Planaltina de Goiás se encontra em um contexto diferente. Este município em momento algum foi visto como uma alternativa para as demandas por habitação não correspondidas pelo DF. Neste vetor, o que se percebe, já há algum tempo, é a ocupação do solo do próprio DF. Nos arredores de Sobradinho e Planaltina, ocorreu um processo vertiginoso de fragmentação do solo para fins de moradia.

Enfim, essa primeira de muitas outras incursões demonstra o quanto a geografia dos municípios goianos e também o leste goiano, foi afetado 
pela transferência da capital. Acostumamo-nos a pensar no papel das cidades médias no território goiano, destacando estudos sobre Jataí, Catalão, Rio Verde e Anápolis. Esquecemos, no entanto, que no interior do Distrito Federal e também no entorno do DF, existem aglomerados urbanos que ultrapassam, do ponto de vista populacional, esses municípios. Mas isso é só uma constatação. O que torna complexa essa geografia é, também, o arranjo institucional e o padrão de mobilidade populacional.

\section{Notas}

1 Reestruturação e fragmentação das cidades-regiões na dinâmica espacial dos Entornos de Goiânia e Distrito Federal. Coordenado pela Profa. Dra. Celene Cunha Monteiro Antunes Barreira.

2 É necessário ressaltar que o DF possui 26 Regiões Administrativas (RA's) e que somente uma parte destas foram diretamente observadas neste trabalho de campo. As Regiões Administrativas foram criadas a partir de 1964, com a lei 4.545 .

3 Sobre este processo de desmembramento ver: MELLO, Marcelo de. Luziânia: a fragmentação territorial de um município do Entorno de Brasília. Dissertação de mestrado. UFG. IESA. 1999.

4 Para maiores informações consultar CAIADO (2005).

\section{Referências}

MELLO, Marcelo de. Luziânia: a fragmentação território de um município do Entorno de Brasília. Dissertação de Mestrado. Goiânia: UFG, IESA, 1999.

GDF. CODEPLAN. Distrito Federal - síntese de informações sócio-econômicas. Brasília: 2006.

CAIADO, Maria Célia Silva. Estruturação intra-urbana na região do Distrito Federal e Entorno: a mobilidade e a segregação socioespacial da segregação. In.: Revista Brasileira de Estudos Populacionais. São Paulo: V. 22, n.1, jan./jun., 2005.

IBGE.Censo demográfico 2000 - Deslocamentos - resultado da amostra. Rio de Janeiro: IBGE, 2003.

Marcelo Antunes - Mestrando em geografia pelo IESA.

Marcelo Mello - Doutorando geografia e prof. da UEG

Tadeu A. Arrais - Doutor em geografia e professor adjunto do curso de geografia do IESA - UFG 


\title{
Estado da arte da Geografia produzida em Goiás: 20 anos do Boletim Goiano de Geografia (1981 - 2001) ${ }^{1}$
}

\author{
Ademir Batista Castorino - UFG \\ ademircastorino@gmail.com
}

\section{Considerações iniciais}

O Boletim Goiano de Geografia já está no seu vigésimo sétimo ano. Dada sua importância, acreditamos que seja o momento oportuno para fazer um balanço de sua caminhada. Essa idéia surgiu na disciplina do Estágio I, na qual propusemos fazer um balanço temático das publicações do BGG, o que resultou em relatório, cuja síntese apresentaremos a partir de agora.

\section{Gráfico 01}

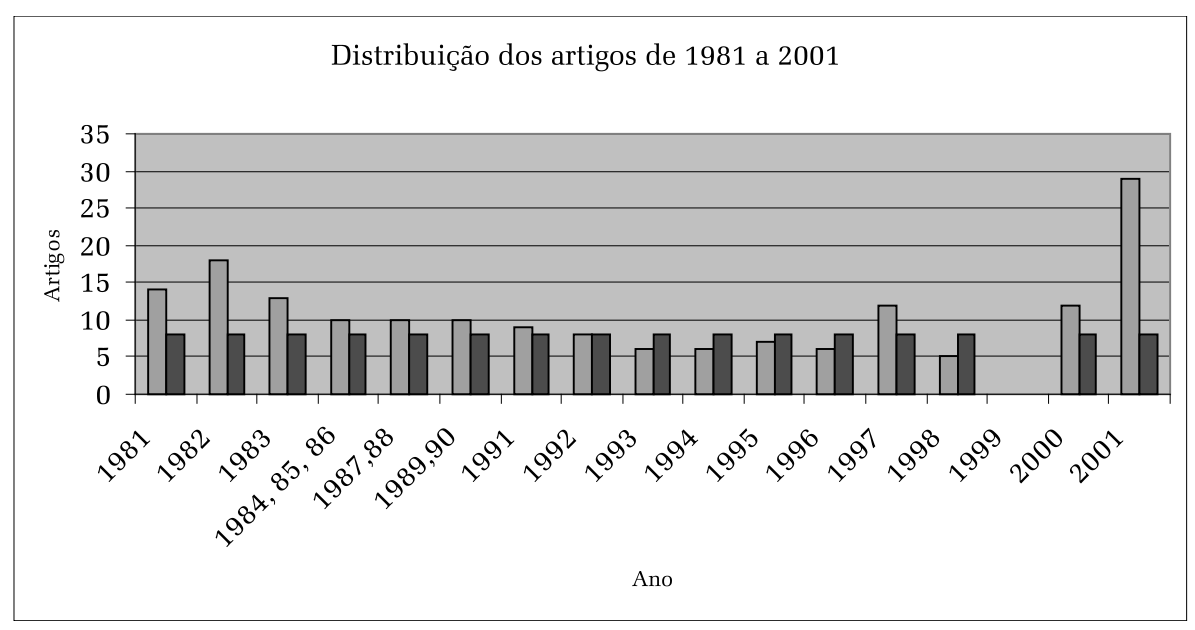

Fonte: BGG

O gráfico apresenta a quantidade de publicações no período. O número vem acompanhado da média de oito publicações por volume; em 1999, não foram publicados artigos, apenas resumos de um congresso internacional. De posse destas informações, faremos um balanço temático das publicações, dos temas, das principais abordagens e dos autores do BGG. 
Tabela 01

\begin{tabular}{c|c}
\hline \multicolumn{2}{c}{ A Produção do BGG em 20 anos (1981 - 2001) } \\
\hline Tipo de Publicação & Número de Publicações \\
\hline Artigos & 143 \\
\hline Resumos de Dissertações & 14 \\
\hline Resumos de Teses & 2 \\
\hline Notas & 6 \\
\hline Resenhas & 8 \\
\hline
\end{tabular}

Fonte: BGG (1981 - 2001)

O texto está estruturado de modo a facilitar a compreensão. Partimos da distribuição dos artigos por volumes; em seguida, trabalhamos os coordenadores, depois ou autores e, por último, os temas. Não há uma ordem para a compreensão do texto, as considerações são feitas em todos os tópicos e arrematadas nas considerações finais.

\section{Coordenadores do BGG}

A série analisada é composta de 175 publicações divididas entre artigos, resumos de teses e dissertações, notas e resenhas, muitos escritos por um mesmo autor. Seus coordenadores foram autores professores do Instituto de Estudos Sócio Ambientais - IESA. O nascimento do BGG dá-se sob a coordenação do então professor Horieste Gomes, no ano de 1981. As edições iniciais trazem, claramente, suas idéias e concepções.

Tabela 02

\begin{tabular}{l|c|c|c}
\hline \multicolumn{1}{c|}{ Coordenadores } & Formação inicial & Ano & Tendências \\
\hline Horieste Gomes & Historiador & 1981 & Gemorfologia \\
\hline Antônio Teixeira Neto & Historiador & 1984 & Biogeografia \\
\hline José Eduardo A M. Costa & - & 1989 & Meio Ambiente \\
\hline Maria Helena M. C Santos & - & 1991 & Geografia Econômica \\
\hline Alfredo Borges Campos & Geógrafo & 1997 & Geografia Urbana \\
\hline Maria Geralda de Almeida & Geógrafa & 2000 & Turismo \\
\hline
\end{tabular}

Fonte: Banco de Dados Pessoal

Fonte: Fonte: BGG (1981 - 2001) 
As tendências do período de coordenação das publicações nem sempre se impõem conforme a orientação do coordenador, embora este não deixe de influenciar, como pôde ser evidenciado nos três primeiros anos do BGG; muito embora fosse coordenado por um estudioso da Geografia Econômica, a tendência seguida foi a Geomorfologia ${ }^{2}$.

Contudo, é importante observar que isso não significa ou, pelo menos, não nos dá legitimidade para falar das influências dos coordenadores sobre as publicações, pois as tendências são classificadas através da quantidade de artigos publicados, enquanto as influências requerem uma análise mais apurada do conteúdo dos artigos.

Um exemplo que nos dá mostras de que as influências do coordenador podem ser visíveis sobre os temas das publicações são os dados dos períodos coordenados pelas professoras Maria Helena M. C Santos e Maria Geralda de Almeida. Durante o período de coordenação de cada uma, percebe-se a centralidade nos temas afins à "Geografia Marxista" ${ }^{3}$ ", no caso da primeira, e a grande atenção dada ao Turismo, no caso da segunda, o que evidencia um papel fundamental de seus coordenadores na proposta editorial do BGG.

\section{Os principais autores do BGG}

O BGG é uma revista de publicações periódicas do curso de geografia do IESA/UFG, dessa forma não é de se estranhar que os professores e pesquisadores do Instituto tenham nele um veículo de divulgação de suas pesquisas e reflexões, como podemos observar no gráfico 02.

A relação entre coordenadores e autores carece de estudos mais precisos. Contudo, o contato com as publicações nos faz crer na hipótese de que os primeiros "influenciaram" os segundos. Outra vertente de entendimento que também pode ser levantada é a de que os coordenadores “apenas” organizaram idéias já difundidas entre os autores.

A média de artigos publicados por autor é de 2,46, considerando os 58 autores que publicaram no BGG de 1981 até 2001. Porém, muitos escreveram apenas um artigo, outros tantos escreveram dois, uma parcela menor escreveu três. Observamos um significativo número de autores que escreveram mais de quatro artigos. No terceiro lugar, compartilhando com o professor Carlos Alberto, está o professor Antônio Teixeira Neto e a partir do quarto lugar as posições são compartilhadas por vários autores. É importante 
que se destaque a participação do professor Miguel Ângelo, pesquisador do Instituto Brasileiro de Geografia e Estatística - IBGE e professor da Universidade Federal do Rio de Janeiro.

\section{Gráfico 02}

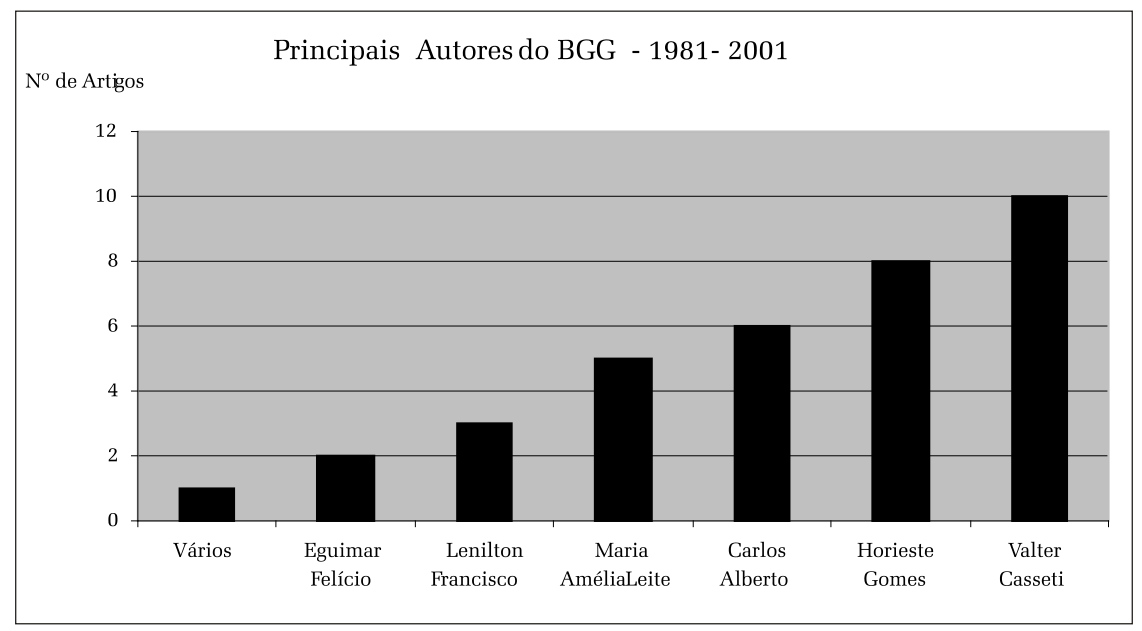

Fonte: BGG (1981 - 2001)

\section{Os principais temas publicados no BGG}

É preciso esclarecer que os temas foram divididos inicialmente em duas categorias: geral e específico, tomando por base a dimensão espacial de cada um. Dessa forma, entendemos como específicas, as publicações que têm por temática o recorte do Estado de Goiás e como gerais aquelas cuja base territorial não está circunscrita aos limites de Goiás.

Por se tratar de uma revista de publicações científicas editada em Goiás, no curso de Geografia sediado no mesmo Estado, que muitas vezes publica reflexões e resultados de pesquisas atinentes aos problemas do Estado, entendemos, então, que as publicações específicas são aquelas que trazem algumas reflexões sobre os problemas concernentes a geografia, vividos pelos goianos. 
Os temas classificados como gerais tratam de muitas geografias, problemas sociais de outros lugares do Brasil: geografia urbana e o problema das grandes cidades brasileiras; e do mundo: geopolítica e questões territoriais no Canadá, Alemanha e Colômbia são alguns dos exemplos. O BGG traz, ainda, reflexões e pensamentos de outros autores que não demonstram uma relação com a proposta do BGG, compondo-se majoritariamente de ensaios reflexivos sobre a geografia, discussões teóricas e opiniões sobre o pensamento geográfico etc.

Essa classificação considerou apenas os artigos, ficando de fora notas e resenhas. Do total, 65\% foram classificados como gerais e 35 específicos. O limite entre o que é um ensaio e um artigo no Boletim é muito tênue; mesmo entre aqueles classificados como publicações específicas, não há uma definição muito clara do que vem a ser cada uma delas. Embora o BGG denomine a maioria de suas publicações como sendo artigos, muitos deles não apresentam uma estrutura compatível com o que comumente assim se classifica.

A divulgação de pesquisas originais ainda é pequena ${ }^{4}$, pelo menos não é feita nos moldes tradicionais da ciência, como faz a Geologia, a Geomorfologia ou mesmo a Geografia em outras universidades. Essa ausência é agravada pelo confuso papel exercido pela Geografia no campo das ciências ou mesmo pela fragmentação do entendimento do que de fato venha a ser Geografia e com que ela deve se preocupar.

Se tivéssemos que usar indicadores de produção geográfica no Estado de Goiás, considerando uma série histórica consolidada e tomando por base o universo acadêmico de produção, a expressão produtiva da Geografia acadêmica em Goiás teria a forma do gráfico $03^{5}$.

Estão apresentados no gráfico os cinco principais temas sobre os quais os professores e pesquisadores tem se ocupado em publicar no BGG, de 1981 até 2001. O destaque é para a geomorfologia. Não por acaso essa linha é muito forte na pesquisa voltada para problemas geomorfológicos de Goiás e da região do Cerrado de uma forma geral.

A forte presença da Geografia Urbana é um fenômeno que só pode ser explicado se nos valermos das influências externas ao IESA/UFG, principalmente da Universidade de São Paulo - USP, onde estudou boa parte dos professores-pesquisadores que atuam em Goiás, uma das razões pela qual ela disputa a liderança com a Geomorfologia. Os estudos das cidades são muito comuns naquela universidade, que é cercada pela maior metrópole do país. Por alguma razão, pode estar ligada ao intercâmbio docente esta 
maneira de pensar a geografia que acabou se infiltrando e se consolidando em uma realidade predominantemente agrícola como a goiana.

\section{Gráfico 03}

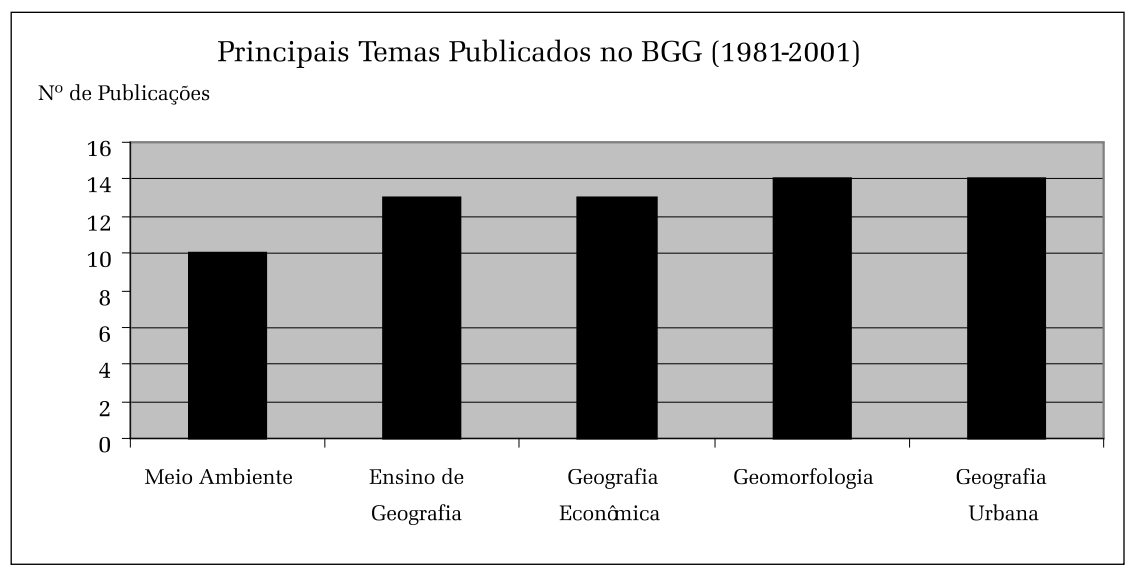

Fonte: Fonte: BGG (1981 - 2001)

A geografia econômica pode ser classificada como geral, uma vez que não tem em Goiás o ponto de partida de suas reflexões feitas, na maioria das vezes, em forma ensaios e sem base espacial definida; são as "leis do marxismo" tentando homogeneizar o espaço que têm no prof. Horieste Gomes seu principal representante.

O ensino de geografia, ao contrário da geografia econômica, traz em sua maioria reflexões cujos pontos de partida são quase sempre a prática do ensino de Geografia no Estado de Goiás. Dos 26 temas catalogados, o ensino é o quarto em numero de publicações. As publicações ligadas à licenciatura gozam de muito prestígio no BGG, o que não é de se estranhar, visto que em Goiás 76\% dos cursos de Geografia oferece apenas a licenciatura como possibilidade de formação.

Há um fator importante a se considerar em relação à classificação dos temas expressa pelo gráfico 03. Estes têm no universo acadêmico do Instituto de Estudos Sócio-Ambientais da Universidade Federal de Goiás, grande significação. Este curso, por sua vez, é parâmetro para os demais cursos desenvolvidos no Estado e é em torno daqueles temas que se desenvolve o curso de geografia do IESA/UFG cuja expressão no BGG compõe-se de três 
correntes majoritárias: Geografia Física (Geomorfológia), Geografia Humana (Geografia Econômica ou Marxista) e o Ensino de Geografia.

Outros temas como a geografia agrária e a migração ocuparam pouco espaço nas publicações, mas sempre se fizeram presentes. Pode-se dizer que são vertentes marginais que não desfrutam de muito prestígio, mas que aparecem, aleatoriamente, em todo período analisado.

A educação ambiental é um tema que surge pelas pressões internacionais em torno da questão ambiental; evidentemente, o BGG não está desligado do mundo, reproduzindo, de uma forma ou de outra, o discurso hegemônico, sendo as ONGs - Organizações Não-Governamentais, a "mola propulsora” desta discussão na mídia geral e especializada.

\section{Considerações finais}

A idéia que fica para os leitores do BGG é a de uma publicação consolidada na difusão do pensamento geográfico em Goiás, pensamento originário de muitas reflexões, geografias, Universidade, Faculdades e Escolas de todo o Estado, mas que também traz reflexões oriundas de pesquisadores de outros Estados: Rio de Janeiro, São Paulo, Tocantins e muitos outros.

Nestes vinte anos de história, o BGG coleciona artigos dos mais renomados estudiosos em Geografia do Estado, alguns bastante reconhecidos nacionalmente, tais como: Antônio Teixeira Neto, Maria Geralda de Almeida, Valter Casseti - nomes que em muito contribuíram e contribuem para a atual consolidação da única publicação periódica especializada em geografia no Estado de Goiás.

O Boletim seguiu uma linha tradicional até o ano de 2000, especializada em ensaios e reflexões gerais. Já a partir do ano 2000, sob coordenação da Professora Maria Geralda de Almeida, a revista começa a apresentar algumas adequações que buscam aproximá-lo das exigências para a indexação de periódicos nacionais pela CAPES: o editorial, o sumário em dois idiomas, um novo projeto gráfico, um conselho editorial mais amplo e o espaço para a publicação de resumos de dissertações e teses da pós-graduação são algumas das mudanças.

Em 2011, o Boletim fará 30 anos e embora esteja atualmente consolidado e qualificado pelas CAPES, há muito ainda por fazer para que tenhamos uma publicação especializada em geografia no Estado de Goiás que sirva de referência para outras publicações especializadas em geografia que venham 
a se estabelecer. Para que seja consolidado na comunidade acadêmica e bem qualificado pelas entidades credenciadas, é preciso ampliar o espaço para pesquisadores externos e dar mais ênfase ao resultado de pesquisas. Esperamos que esses gargalos possam ser superados nos próximos anos.

Título do Periódico: Boletim Goiano de Geografia

\begin{tabular}{c|c|c|c|c}
\hline ISSN & Título & Qualidade & Circulação & Área de Avaliação \\
\hline 0101-708X & Boletim Goiano de Geografia & A & Local & Multidisciplinar \\
\hline 0101-708X & Boletim Goiano de Geografia & B & Nacional & Geografia \\
\hline $0101-708 X$ & Boletim Goiano de Geografia & C & Nacional & Geociências \\
\hline
\end{tabular}

Fonte: CAPES 2007.

\section{Notas}

1 Agradeço a todos que diretamente ou indiretamente participaram deste trabalho. Em especial à equipe do BGG que garantiu o acesso irrestrito aos arquivos. Ao professor Tadeu Alencar Arrais, coordenador editorial, agradeço pelas conversas. Ao professor Eguimar F. Chaveiro, com quem dividi as primeiras idéias desta pesquisa, que mais tarde se tornou objeto de duas das três disciplinas do estágio supervisionado, deixo um agradecimento especial.

2 Nos três primeiros anos do BGG, foram publicados sete artigos que tratavam sobre gemorfologia, como exemplo pode-se citar o artigo Geomorfologia do Município de Goiânia-GO de Valter Casseti.

3 Carlos Eduardo dos Santos Maia escreve um artigo que merece destaque: Teoria Marxista da evolução urbana: uma breve introdução.

4 A quantidade de pesquisas originais publicadas é de difícil precisão, estimamos que varie entre 10 e $15 \%$ de todas as publicações analisadas.

5 O Instituto Histórico e Geográfico de Goiás - IHGG tem boa parte de suas publicações alinhadas com o que podemos chamar de uma "historiografia ou uma geografia literária de Goiás"

\section{Referências}

Boletim Goiano de Geografia. Goiânia: Editora UFG, 1981 a 2001. Anual/semestral. ISSN 0101$708 \mathrm{X}$

CASSETI, V. Geomorfologia do Município de Goiânia-Go. Boletim Goiano de Geografia, v. 12, n. 1, p. 65-85, 1992.

CASTORINO, A. B. Banco de dados, Excel, armazenamento de dados do Boletim Goiano de Geografia - BGG - 1981 - 2001. 
Critério de Implantação QUALIS-2005. CAPES - Coordenação de Aperfeiçoamento de Pessoal de Nível Superior. Acesso em www.capes.gov.br/qualis_2005. Julho de 2006.

FERREIRA, Norma Sandra. A. As Pesquisas Denominadas "Estado Da Arte" in: Educação \& Sociedade, Ano XXIII, No 79, Agosto/2002.

GOMES, Horieste, A Produção Geográfica Em Goiás, in, O Espaço Goiano: abordagens geográficas/ Antônio Teixeira Neto... [et al.]; org. [por] Horieste Gomes. - Goiânia, Associação dos Geógrafos Brasileiros, 2004.

MAIA, C. E. S.; Teoria Marxista da evolução urbana: uma breve introdução. In. Boletim Goiano de Geografia, v 16, n. 1 p. 25-41 1996.

Ademir Batista Castorino - Graduado em geografia pelo IESA. 



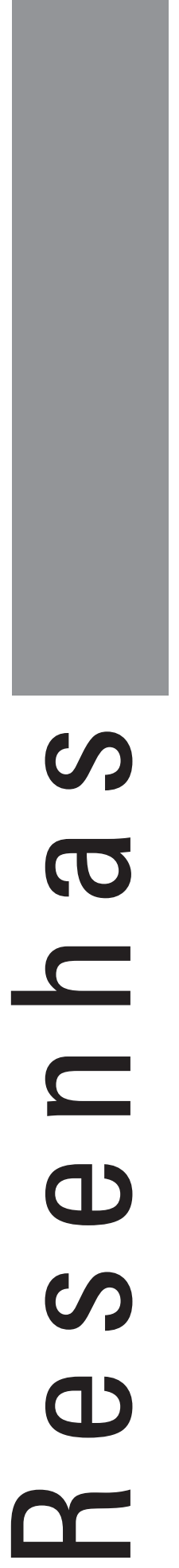





\title{
RESENHA
}

ELIAS, Denise; PEQUENO, Renato (Orgs.) Difusão do Agronegócio e Novas Dinâmicas Socioespaciais. Fortaleza: Banco do Nordeste, 2006. 483p.

\author{
Rosimary Gomes Rocha - UFG \\ rosegeografia@hotmail.com
}

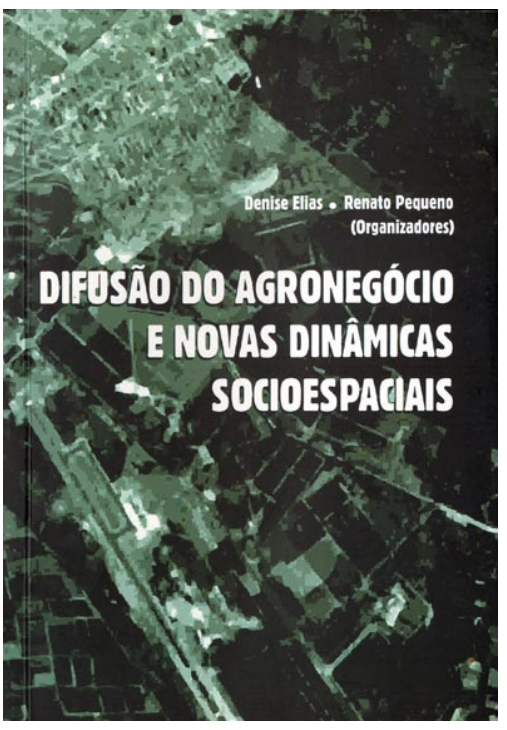

A obra intitulada Difusão do Agronegócio e Novas Dinâmicas Socioespaciais, organizada por Denise Elias e Renato Pequeno, professores da Universidade Estadual do Ceará e da Federal do Ceará, respectivamente, encontra-se dividida em três partes. Ao todo, são quatorze textos elaborados por diferentes autores. O tema principal são as transformações recentes ocorridas no Nordeste a partir da implantação do agronegócio, da sojicultura, da fruticultura irrigada e das novas relações de trabalho surgidas nesta região a partir de um novo uso do tempo e do espaço.

Pode-se dizer, sem exageros, da importância assumida pela obra, principalmente por discutir os processos de implantação da agricultura modernizada no Nordeste brasileiro, situando, de forma pertinente, as desigualdades socioespaciais surgidas no contexto da modernização que tem como principal componente desse processo as políticas e as ações baseadas na reprodução do capital monopolista.

Maria Encarnação Beltrão Sposito é a responsável pelo prefácio que faz uma síntese minuciosa das principais questões abordadas nos diversos artigos e chama a atenção para a coerência teórico-conceitual, valorização das escalas e interação entre o urbano e o rural existente nessa coletânea.

Denise Elias inicia as discussões com o texto: Pensando os espaços agrários luminosos do Nordeste do Brasil. Através dessa leitura, pode-se compreender os novos arranjos territoriais produtivos no Nordeste, fruto da 
dispersão do agronegócio pelo território brasileiro e inserção dos lugares de reservas à produção e ao consumo da agropecuária globalizada. A autora deixa claro, ainda, que o objetivo do livro é discutir os processos que regem a difusão do agronegócio, os elementos da estrutura social e agrária e os impactos para o incremento da urbanização. Há, ainda, um relato da história do livro, no qual são citadas as Universidades, os Programas e os pesquisadores que colaboraram com a construção do referido trabalho.

A primeira parte da coletânea tem como tema: Um Novo Nordeste. O primeiro texto: Agronegócio e Desigualdades Socioespaciais, da professora Denise Elias, aborda a formação de um novo arranjo territorial produtivo no espaço agrário Nordestino como resultado da introdução, nesta região, do meio técnico-científico-informacional. Enfatiza-se que, ao contrário das regiões sul e sudeste, o processo de difusão do agronegócio no Nordeste tem se dado de forma descontígua, resumindo-se a determinados pontos, a que ela denomina de pontos luminosos.

Entretanto, ressalta que, paralelamente ao crescimento econômico, gerado pela implantação do agronegócio, da-se o avanço dos impactos negativos em termos sociais, territoriais e ambientais e se formam novos circuitos produtivos vinculados ao capital globalizado, articulado através de fluxos rápidos.

Como exemplos dos novos arranjos territoriais, destacam-se três como principais: a produção de frutas que se estende do Baixo curso do Rio Açu $(\mathrm{RN})$ ao Baixo curso do Rio Jaguaribe (CE), o composto pela região polarizada pelos municípios de Juazeiro (PE) e Petrolina (BA), também associado à produção de frutas tropicais, e, por último, o complexo da soja nos cerrados nordestinos, abrangendo o oeste da Bahia, o sul do Maranhão e o sul do Piauí. A problemática da concentração fundiária na região e as transformações que vem passando o espaço urbano, como por exemplo, o crescimento desordenado e acirramento da divisão do trabalho e uso racional do solo também são elementos em destaque no referido texto.

O texto de Edgard Porto se refere às distintas fases de implantação das políticas de desenvolvimento regional no Brasil, na medida em que busca traçar a caracterização do papel e das ações do Estado brasileiro após a década de 1950, dando ênfase às propostas da PNDR (Política Nacional de Desenvolvimento Rural) e seus reflexos na região Nordeste. Um outro aspecto relevante é a análise da flexibilidade da circulação a nível mundial, permitido pelos avanços tecnológicos e que tem propiciado a territorialização dos espaços pelo capital.

Na segunda parte do livro que tem como eixo a Expansão da Fruticultura e da Soja no Nordeste, as discussões são introduzidas por Josefa 
Salete Barbosa Cavalcanti, Dalva Maria da Mata e Pedro Carlos Gama da Silva, autores do artigo: Transformações Recentes nos Espaços de Fruticultura do Nordeste do Brasil. Os autores discorrem sobre as políticas destinadas ao aproveitamento das águas das barragens localizadas no Rio São Francisco, tendo como objetivo principal o cultivo de legumes e frutas tropicais, desde 1980, na região dos municípios de Petrolina - PE e Juazeiro - BA, e outro no Vale do Açu-Mossoró-RN. Para os autores, toda essa dinâmica tem gerado mudanças estruturais no espaço em análise, através de privilégios às empresas e redução do número de empregos, proporcionando formas precárias de parcerias e grande exclusão e desigualdades sociais.

No texto seguinte, Soraia de Fátima Ramos, escreve sobre a introdução do processo de modernização seletiva nos municípios de Petrolina-PE e Juazeiro-BA. Para tanto, faz uma descrição histórica das práticas e uso territorial e discute o uso racional das técnicas como elemento preponderante para a seletividade espacial.

O artigo de Maria Dione Carvalho de Moraes, intitulado: Do destino pastoril à vocação agrícola: modernização agrícola dos cerrados e inflexões discursivas nas narrativas mestras do Piauí, relaciona a passagem do imaginário social do Piauí como estado agropastoril para a vocação agrícola modernizada, através das narrativas mestras. A autora conceitua este fato como inflexão do ideário do destino pastoril que data da década de 1970 - 1980, período em que se inicia a transformação territorial no referido estado pela introdução de uma nova forma de produzir baseada em técnicas avançadas que culminou na modernização do espaço agrário.

O quarto artigo da segunda parte do livro, de Maria do Socorro Lira Monteiro e Terezinha de Jesus Alves Aguiar, aborda os consensos e as políticas econômicas condicionantes de ocupação do cerrado brasileiro e, especificamente, em Uruçuí-PI, a partir da década de 1970, e faz uma relação desse fenômeno com as políticas ambientais aplicadas na área em análise, como por exemplo: decretos, legislações e licenças ambientais.

Vicente Lemos Eudes Alves, estuda o sul do Piauí enquanto espaço inserido na modernidade pelo incremento das técnicas avançadas de produtividade agropecuária, incorporando novas funcionalidades, tanto no campo como nas cidades, integrando esta região aos circuitos nacionais e globais do sistema capitalista.

A terceira parte do livro é composta por artigos direcionados à análise do novo espaço frutícola globalizado, localizado no Baixo Jaguaribe-CE. 
As discussões são iniciadas por Alexandra Muniz, que, em seu artigo, faz uma leitura da nova dinâmica do trabalho agrícola do Baixo Jaguaribe e do uso de tecnologia para a irrigação associada ao de insumos modernos para o cultivo de arroz e frutas, Destaca ainda, que a reestruturação produtiva não é benéfica para a maior parte da população devido aos baixos salários, concentração fundiária e do poder político nessa região.

A estrutura fundiária também é tema do artigo de Francisco Kennedy Silva dos Santos, que discute as relações de determinantes de preço e uso das terras do Perímetro Irrigado de Morada Nova, a exemplo de alguns textos já citados anteriormente, os planos, programas e ações governamentais que expressam as mudanças da agropecuária brasileira são expostos para que se possa compreender o contexto de redefinição da estrutura e dos preços da terra na área da pesquisa.

Andréa Ballestero dedica-se à compreensão do Baixo Jaguaribe pela ótica das políticas públicas de irrigação no Ceará, responsável pela re-configuração do espaço geográfico local. Segundo a autora, a implantação da reforma do setor hídrico Cearense nos anos 90, tem resultado na participação de atores tradicionalmente excluídos das instituições políticas e das dinâmicas produtivas. As políticas de irrigação baseiam-se, ainda, na inserção do Estado do Ceará no discurso modernista, entretanto tem sido quase inexistente a democratização do acesso a água para a maioria da população rural.

No texto escrito por Maria Lucenir Jerônimo Chaves, a análise se concentra no papel regional de Limoeiro do Norte. O artigo mostra que há uma redefinição dessa sub-região após o advento da modernização da agricultura, que se dá por Projetos governamentais, neste caso, as transformações ocorridas no urbano são comandadas pelo campo. Limoeiro do Norte passa a apresentar assim, uma nova função regional no momento em que guarda uma íntima relação com as articulações intra-urbanas.

Continuando com as discussões sobre a cidade e o urbano, Renato Pequeno mostra que houve uma alteração dos espaços intra-urbanos no Baixo Jaguaribe. Para isso, traça uma análise da evolução recente dessa sub-região abrangendo os caracteres referentes à demografia, uso do solo, transportes, infra-estrutura e elementos sociais, de planejamento e desenvolvimento urbano.

Francisco Rérisson Carvalho Correia Máximo escreve sobre a produção da moradia no Baixo Jaguaribe com o advento da agricultura moderna. Nesta região, as políticas públicas baseadas em isenções fiscais e especulação fundiária favorecem a problemática da segregação do espaço que é 
abordada como elemento pra se compreenderem as diversidades socioeconômicas presentes na localidade.

Ao fechar a terceira e última parte desta obra, o artigo de Edílson Pereira Júnior e Diego Gadelha tem como foco a atividade industrial calçadista no município de Russas. As discussões se pautam na redefinição das dinâmicas socioespaciais no espaço urbano propiciadas por incentivos estaduais para a instalação da indústria de calçados da marca Dakota S/A. Todo esse contexto tem propiciado um fluxo migratório para a cidade, ocasionando um novo dinamismo urbano.

Os autores Denise Elias e Renato Pequeno, através da organização desta coletânea, nos fazem compreender as principais questões pertinentes aos processos de reorganização dos espaços agrícolas e urbanos incorporados aos circuitos produtivos do capital globalizado no Nordeste brasileiro. Um aspecto de suma importância é a valorização existente entre as diferentes escalas articuladas ao empírico, mostrando assim que a agropecuária comandada pelo agronegócio inaugura uma unidade indissociável entre o rural e o urbano.

O trabalho contou com apoio financeiro do CNPq, inclusive no concernente à pesquisa de campo. Nos anexos, encontra-se exposto um conjunto de fotos referentes aos novos circuitos agrícolas do Nordeste brasileiro, objeto de estudo dos artigos que compõe esta coletânea.

Os temas e as discussões abordados nos diferentes textos nos valem como pressuposto teórico e metodológico para estudos direcionados à compreensão da articulação dos pontos "luminosos" da região Nordeste ao circuito da economia global. 



\section{RESENHA}

Latrubesse, Edgardo; Carvalho, Thiago.

Geomorfologia do Estado de Goiás e Distrito Federal. Goiânia:

Secretaria de industria e comercio. 2006. 127 p.

\section{Thiago Morato de Carvalho}

tmorato@infonet.com.br

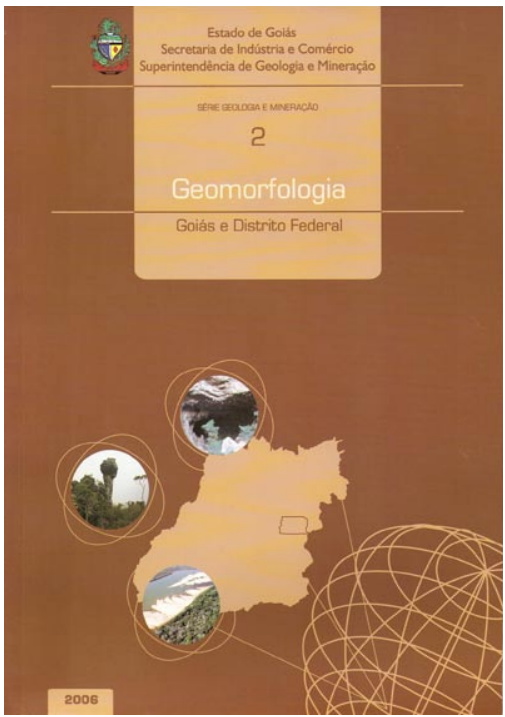

O livro Geomorfologia de Goiás e Distrito Federal da Série Geologia e Mineração volume 2 , foi editado pelo Governo de Goiás através da secretaria de Indústria e Comércio - Superintendência de Geologia e Mineração no ano de 2006. Essa obra retrata de forma didática as características morfológicas do relevo do Estado de Goiás e Distrito Federal ajustadas na escala 1:250000. O livro é resultado de pesquisas anteriores e novas investigações realizadas pela equipe de pesquisadores da Universidade Federal de Goiás; Dr. Edgardo Manuel Latrubesse, MSc. Thiago Morato de Carvalho (doutorando em Ciências Ambientais) e da Universidade de Guarulhos Dr. José Cândido Stevaux.

O primeiro capítulo descreve as técnicas e métodos utilizados na elaboração do mapa geomorfológico, como o uso de técnicas de sensoriamento remoto e geoprocessamento utilizando imagens IFSAR - Interferometric Synthetic Aperture Radar, que foi ferramenta importante na interpretação de geoformas, suas semelhanças e relações. Outras ferramentas utilizadas foram: cartas topográficas do IBGE escala 1: 250.000 com curvas de nível com eqüidistância de 100 metros; imagens Landsat 7 ETM+; produtos gerados a partir das imagens SRTM (Shuttle Radar Topography Mission), tais como, perfis topográficos, relevos sombreados e hipsometria; mapa geológico; e mapa de drenagem. A interpretação foi realizada em meio analógico e 
digital, com uso dos softwares ENVI 4.0, ERDAS Imagine 8.7, ArcView $3.2 \mathrm{e}$ SPRING 3.4. O mapeamento gerou produtos na escala 1:250.000, 1:500.000 e 1:1.000.000 digitalizados, modelados e formatados na Superintendência de Geologia e Mineração da SIC sob supervisão da MSc. Maria Luiza Ośorio. O mapeamento contou ainda com pesquisa de campo para corroborar e descrever as principais geoformas identificadas e elaborar perfis que auxiliaram na interpretação da compartimentação geomorfológica. Neste trabalho, aplicouse uma classificação do tipo genético. Essa classificação está organizada em vários níveis, sendo as categorias dominantes a de Sistemas Agradacionais e as de Sistemas Denudacionais.

No segundo capítulo apresentam-se as diferentes formas denudacionais que predominam no Estado de Goiás e Distrito Federal. No Estado de Goiás, há uma expressiva predominância de formas denudacionais ocupando $98,30 \%$ da sua superfície $\left(346.882 \mathrm{~km}^{2}\right)$. As formas denudacionais foram subdivididas em dois grandes grupos: aquelas com forte controle estrutural e as com fraco ou nenhum controle estrutural. Dentre as unidades denudacionais sem ou com fraco controle estrutural se destacam as Superfícies Regionais de Aplainamento (SRA), nas quais foram identificadas quatro SRAs variando em diferentes patamares (altitudes), diversas associações de morros e colinas (MC) e as Zonas de Erosão Recuante (ZER) estas associadas a evolução das SRAs. Entre os relevos com forte controle estrutural se destacam colinas em terrenos dobrados, formando hogbacks, e estruturas dômicas em dobras, braquianticlinais, geralmente associadas a corpos intrusivos. Os sistemas cársticos também estão presentes no estado, porém com pequena expressão cartográfica e associados a outras unidades espacialmente mais representativas.

O capítulo seguinte apresenta os sistemas de agradação, estes ocupam 1,70\% de Goiás, sendo absolutamente dominantes os sistemas de agradação fluvial cuja planície aluvial do Rio Araguaia é a mais expressiva no estado, juntamente com as planícies de seus afluentes. Neste capítulo, foi feita uma síntese da rede de drenagem e planícies fluviais do Estado, com ênfase no rio Araguaia. Além dos sistemas fluviais, os sistemas lacustres também fazem parte dos sistemas agradacionais, os quais ocorrem restritamente na $\mathrm{Su}$ perficíe Regional de Aplainamento IV; por nesta ocorrerem principalmente níveis lateríticos bem desenvolvidos, os lagos geralmente possuem formas arrendondadas e dimensões reduzidas (algumas dezenas de metros), porém podem atingir centenas de metros ou quilômetros de comprimento.

No capítulo 4, Geomorfologia Aplicada, se faz uma correlação com a geomorfologia e demais processos geomórficos, como a relação dos mantos 
de intemperismo e lateritas e seu potencial econômico no Estado de Goiás. Os depósitos de ouro associados com as coberturas lateríticas ocorrem sobre a SRAIIA, assim como jazidas de manganês geradas por processos de laterização que estão distribuídas principalmente sobre a SRAIIA. Outras morfologias e associações aos processos mecânicos e de imtemperismo também são discutidas neste capítulo como inselbergs e tors; stone lines; placers e planícies fluviais; processos erosivos; correlação entre geomorfologia e uso do solo; processos erosivos de sedimentação e mudanças geomorfológicas no Rio Araguaia; correlação entre geomorfologia e hidrogeologia; sítios geomorfológicos - patrimônio natural; uma síntese do quaternário no Estado de Goiás e enchentes na cidade de Goiás. Esta síntese dos processos geomorfológicos associados aos recursos minerais, hídricos e sociais é importância para elaboração de planos de ordenamento territorial e demais políticas públicas para o planejamento urbano, rural e gestão ambiental.

O último capítulo do livro Geomorfologia de Goiás e Distrito Federal apresenta alguns modelos teóricos da evolução da paisagem, sendo os mais conceituados o de King, Davis e Budel. Analisando juntamente estes modelos, podemos fornecer alternativas para a evolução do relevo do Estado de Goiás e Distrito Federal. O conceito de King baseia-se na existência de movimentos de reativação tectônica de forma rápida em relação aos longos períodos intermediários de denudação, assim como no retrocesso que sofrem as vertentes de forma paralela. Conforme ocorre o retrocesso das vertentes, estas articulam-se com os pedimentos; estes, com o passar do tempo, coalescem formando extensas superficíes aplainadas, denominadas de pediplanos. O modelo de Davis refere-se ao controle do ciclo de erosão para a geração da peneplanície, e que possui um ciclo evolutivo passando por uma idade jovem, madura e senil. Este modelo explica a evolução da paisagem com o delínio progressivo de energia potencial do relevo que está sobre o nível do mar, que tende a se estabilizar ao chegar ao nível base de erosão (ao nível do mar); ou seja, as vertentes se tornam mais suaves à medida que perdem material (são erodidas). Budel elaborou o modelo de etchplanação, ou denominado de dupla superfície de planação, este modelo explica que a denudação de uma superfície está associada, simultaneamente, aos processos de erosão superficial e decomposição química profunda, este processo gera uma superfície denominada de etchplano. Dependendo da estrutura interna da superficie e litologia, poderá ocorrer um manto irregular intemperisado, as litologias mais resistentes a este processo formam morfologias peculiares como tors, inselbergs e campos de blocos e matacões. Dentre estes três modelos, o de Budel é o qual mais se enquadra, porém não é suficiente 
para explicar a evolução das SRAs de Goiás, por não levar em consideração os sistemas fluviais como sistemas dinâmicos e modificadores do relevo por retrocesso das vertentes como agentes erosivos.

Thiago Morato de Carvalho - Pesquisador Colaborador do Laboratório de Geologia e Geografia Física - LABOGEF/ IESA - Doutorando em Ciências Ambientais/UFG 


\section{RESENHA}

CANCLINI, Néstor García. Culturas híbridas: estratégias para entrar e sair da modernidade. Trad. Heloísa P. Cintrão e Ana Regina Lessa. 2.ed. São Paulo: Edusp, 1998. $392 p$.

\section{Ivanilton José de Oliveira}

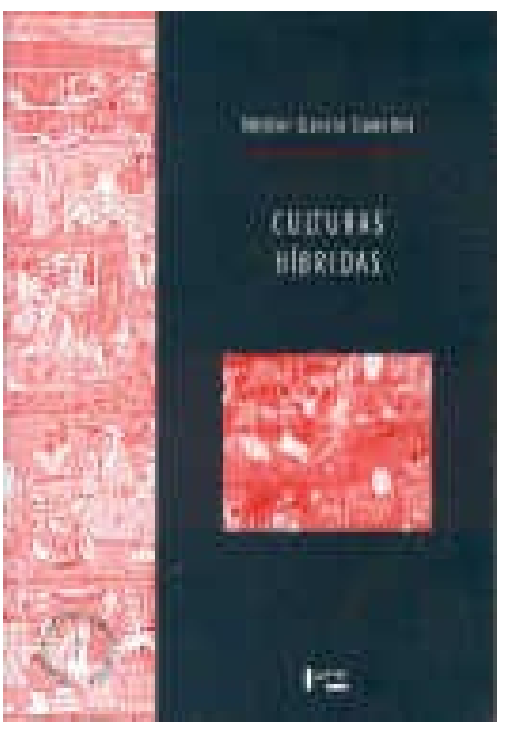

O mexicano Néstor Canclini expõe, nesta obra, suas avaliações acerca das relações entre a modernidade sociocultural e a modernização econômica no conjunto dos países da América Latina - mas com ênfase em alguns deles, como a Argentina, o Brasil e o México.

O livro é estruturado em 7 capítulos, antecedidos de uma Entrada e sucedidos por uma Saída. Assim como aparece já em seu subtítulo, o autor apresenta sua obra, na Entrada, questionando sobre quais seriam, nos anos 90, as estratégias para entrar e sair da modernidade. Em especial na América Latina, "onde as tradições ainda não se foram e a modernização não terminou de chegar".

Canclini foca sua atenção nos papéis dos agentes sociais envolvidos na construção dos produtos culturais ditos cultos, populares ou massivos (aqueles ligados à produção da indústria cultural) e suas relações com a modernidade. Para tanto, ele apresenta as estratégias de diversos setores, como os artistas, os literatos, os museus, as disciplinas sociais (especialmente a Antropologia e a Sociologia), a mídia e as classes políticas, na abordagem do que é tradicional e do que é moderno, para então reforçar a idéia de que, na América Latina, há uma longa história de construção de uma cultura híbri$d a$, em que a modernidade é sinônimo de pluralidade, mesclando relações entre hegemônicos e subalternos, tradicional e moderno, culto, popular e massivo. 
Para justificar sua forma de abordagem, Canclini apresenta-nos três hipóteses: a primeira, de que a incerteza em relação ao sentido e ao valor da modernização deriva não apenas do que separa nações, etnias e classes, mas também dos cruzamentos socioculturais em que o tradicional e o moderno se misturam; a segunda, de que o trabalho conjunto das ciências sociais pode gerar outro modo de conceber a modernização latino-americana, mais do que como uma força alheia e dominadora que busca substituir o tradicional, como as tentativas de renovação com que diversos setores se encarregam da heterogeneidade multitemporal de cada nação; e, a terceira e última, de que o olhar transdisciplinar sobre os circuitos híbridos tem conseqüências que extrapolam a investigação cultural. "O estudo da heterogeneidade cultural é uma das vias para explicar os poderes oblíquos que misturam instituições liberais e hábitos autoritários, movimentos sociais democráticos e regimes paternalistas, e as transações de uns com outros".

No primeiro capítulo, Das utopias ao mercado, Canclini afirma que é possível condensar as interpretações atuais do que seja moderno dizendo que quatro movimentos básicos constituem a modernidade: um projeto emancipador, um projeto expansionista, um projeto renovador e um projeto democratizador. Ao final do livro, o autor retoma esse enfoque para demonstrar como esses quatro movimentos ocorreram na América Latina.

O autor enfatiza, neste capítulo, o papel dos agentes do meio artístico, que travam um embate entre a busca pelo mercado e, ao mesmo tempo, a luta pela distinção de sua produção em relação aos meios massivos. Nas palavras do autor, as sociedades modernas necessitam ao mesmo tempo da "divulgação" - ampliar o mercado e o consumo dos bens para aumentar a margem de lucro - e da "distinção" - que, para enfrentar os efeitos massificadores da divulgação, recria os signos que diferenciam os setores hegemônicos (p. 37).

Por sua vez, a internacionalização do mercado artístico está cada vez mais associada à transnacionalização e concentração geral do capital. A autonomia dos campos culturais não se dissolve nas leis globais do capitalismo, mas se subordina a elas com laços inéditos (p. 62). Canclini exemplifica isso ao abordar como o mercado da arte, valorizando as obras de "mestres" a um nível estratosférico, tem inviabilizado a permanência desse tipo de produto nos museus, ao mesmo tempo em que o "poder" sobre as exposições se desloca para as grandes galerias dos EUA, Alemanha, França e Japão (o mercado sobrepuja a autonomia das elites).

Para o autor essa situação é paradoxal: no momento em que os artistas e os espectadores "cultos" abandonam a estética das belas-artes e das van- 
guardas porque sabem que a realidade funciona de outro modo, as indústrias culturais, as mesmas que encerraram essas ilusões na produção artística, reabilitam-nas em um sistema paralelo de publicação e difusão.

Outro paradoxo apresentado pelo autor é o de que o discurso da sociologia da cultura moderna, de um desenvolvimento autônomo dos campos artísticos e científicos como chave da estrutura contemporânea, não condiz com as práticas artísticas dos últimos vinte anos, que apresentam uma descentralização dos campos e dependência inevitável com relação ao mercado e às indústrias culturais.

No segundo capítulo, Contradições latino-americanas: modernismo sem modernização?, o autor apresenta uma discussão sobre o descompasso entre a modernização socioeconômica e o modernismo literário-artístico.

Com base num artigo de Perry Anderson (Modernity and revolution), o autor desvincula a suposta reciprocidade entre a modernização e o modernismo, tanto na Europa quanto na América Latina. "Ser culto e inclusive ser culto moderno, implica não tanto vincular-se a um repertório de objetos e mensagens exclusivamente modernos, quanto saber incorporar a arte e a literatura de vanguarda, assim como os avanços tecnológicos, matrizes tradicionais de privilégio social e distinção simbólica” (p. 74).

Para Canclini, a América Latina registra uma "heterogeneidade multitemporal" em sua cultura moderna e as críticas ao "descompasso" negligenciam os vínculos das criações artísticas/literárias com os conflitos internos nas sociedades e os obstáculos para comunica-las aos seus povos, dado o analfabetismo (atraso social). As contradições entre modernismo e modernização condicionam as obras e a função sociocultural dos artistas. A modernização cultural não espelha apenas um transplante daquilo que ocorre na Europa, "sobretudo nos principais artistas plásticos e escritores, mas de reelaborações desejosas de contribuir com a transformação social” (p. 79).

O modernismo latino, em muitos casos, deu impulso para a construção da identidade nacional, embora alguns projetos de inserção social tenham se diluído parcialmente em "academismos, variantes da cultura oficial ou jogos do mercado". Para o autor, contudo, “[...] seria preciso entender a sinuosa modernidade latino-americana repensando os modernismos como tentativas de intervir no cruzamento de uma ordem dominante semi-oligárquica, uma economia capitalista semi-industrializada e movimentos sociais semitransformadores" (p. 83).

Entre os anos 50 e 70, fenômenos estruturais - como a expansão urbana, o desenvolvimento econômico, a massificação das relações culturais, 
entre outros - transformaram as relações entre modernismo cultural e modernização social. Estabeleceu-se, contudo, um confronto entre a lógica socioeconômica do crescimento do mercado (literário e artístico) e a lógica voluntarista do culturalismo político. O voluntarismo cultural declinou pelo incremento diferenciado de investimentos nos mercados de elite e de massa, acentuando seu afastamento.

Canclini conclui que, em um certo momento, embora o Estado latinoamericano tenha procurado administrar e se responsabilizar pelo patrimônio cultural, especialmente o tradicional, a iniciativa privada - a indústria cultural - passa a assumir tanto a promoção da cultura moderna para as massas quanto para as elites (seria o caso da Televisa, no México; da Rede Globo, no Brasil; e do Grupo CAYC, na Argentina).

O capítulo três, Artistas, intermediários e público: inovar ou democratizar, é utilizado por Canclini para discutir as relações entre a modernidade e a democratização do acesso à cultura (um dos "pilares" da modernização). Para o autor, o construtivismo plástico e arquitetônico manifestou-se na América Latina antes mesmo de fazer parte do desenvolvimento produtivo porque, mais que reflexo do que auge tecnológico, ele procurou dar o impulso modernizador (p. 116).

O autor apresenta uma ampla exposição sobre o papel de alguns artistas/literatos, como Paz e Borges, acerca de suas críticas à modernização latino-americana, na figura da ação do Estado, e seu apego ao modernismo como forma de resgate de uma formação "nacional". Visível contradição, tendo em vista o elitismo da linguagem. Por sua vez, mostra artistas plásticos engajados numa produção modernista mas focada numa relação com o passado tradicional latino ou o que a formação latina tem de diferenciada, mas que não se enquadram nos moldes da indústria cultural e são, por isso mesmo, alijados do "mercado".

Voltando seu enfoque para o ponto de vista dos receptores quanto à modernidade, Canclini afirma que na América Latina o frágil enraizamento na própria história dificulta buscar numa análise dos museus o entendimento de como a modernidade é vista, até por uma deliberada opção pelo predomínio da cultura escrita sobre a visual (o que alijava a maioria analfabeta do contato com tais produções). De acordo com o autor, "não chegamos a uma modernidade, mas a vários processos desiguais e combinados de modernização" (p. 154).

Por sua vez, a democratização da cultura é pensada como se se tratasse de anular a distância e a diferença entre artistas e público, como na utopia 
de socializar a cultura moderna, tentada pelas revoluções latino-americanas e por regimes populistas. Para o autor, "há um componente autoritário quando se quer que as interpretações dos receptores coincidam inteiramente com o sentido proposto pelo emissor. Democracia é pluralidade cultural, polissemia interpretativa” (p. 156).

No capítulo quatro, $\mathbf{O}$ porvir do passado, Canclini apresenta o embate entre os setores tradicionais e os setores modernos nas sociedades latinoamericanas, quanto ao patrimônio cultural - que tem nos museus o agente principal de sua "salvaguarda".

De acordo com o autor, para entender o desenvolvimento ambivalente da modernidade, é preciso analisar a estrutura sociocultural das contradições presentes em alianças entre os grupos tradicionalistas (fundamentalistas culturais e religiosos) e renovadores (grupos econômicos e tecnocráticos modernizadores). Por sua vez, o patrimônio cultural é o lugar onde melhor sobrevive hoje a ideologia dos setores oligárquicos - o tradicionalista substancialista -, que fixaram o alto valor de certos bens culturais (centros históricos de grandes cidades, música clássica, saber humanístico, folclore etc.). Preservar tais bens teria um caráter estético e simbólico, de embate com a descaracterização promovida pela modernização.

As "tradições" são ritualizadas para servir à legitimação daqueles que as construíram ou se apropriaram delas: uma teatralização do patrimônio cultural que tem a escola como palco fundamental por meio dos conteúdos conceituais do ensino, assim como as celebrações, festividades, exposições e visitas a lugares míticos. A comemoração tradicionalista assenta-se freqüentemente sobre o desconhecimento do passado.

Analisando o papel dos museus, Canclini destaca que "Se o patrimônio é interpretado como repertório fixo de tradições, condensadas em objetos, ele precisa de um palco-depósito que o contenha e o proteja, um palco-vitrine para exibi-lo" (p. 169). E que "Hoje devemos reconhecer que as alianças, involuntárias ou deliberadas, dos museus com os meios de comunicação de massa e o turismo foram mais eficazes para a difusão cultural que as tentativas dos artistas de levar a arte para as ruas" (p. 170).

Os museus, por sua vez, valem-se de rituais para expressar como abordam o patrimônio. A exclusão dos não-iniciados em tais rituais, portanto, continua latente. Segundo Bourdieu, esses ritos instituem uma diferença duradoura entre os que participam e os que ficam de fora (p. 192). E a cultura tradicional busca "naturalizar" essa barreira entre incluídos e excluídos, usa 
a encenação cultural para proclamar que a organização social arbitrária é assim e a não poderia de outra forma.

No quinto capítulo, A encenação do popular, Canclini analisa o papel de alguns agentes na criação de uma "imagem" distorcida do que vem a ser a cultura popular.

A primeira crítica do autor refere-se ao recorte do objeto de estudo: "Interessam mais os bens culturais - objetos, lendas, músicas - que os agentes que os geram e consomem. Essa fascinação pelos produtos, o descaso pelos processos e agentes sociais que os geram, pelos usos que os modificam, leva a valorizar nos objetos mais a sua repetição que sua transformação" (p. 211).

Canclini define o popular como sendo o excluído: aqueles que não têm patrimônio ou não conseguem que ele seja reconhecido e conservado; os artesãos que não chegam a ser artistas, a individualizar-se, nem a participar do mercado de bens simbólicos "legítimos"; os espectadores dos meios massivos que ficam de fora das universidades e dos museus, "incapazes" de ler e olhar a alta cultura porque desconhecem a história dos saberes e estilos (p.205). O popular costuma ser associado ao pré-moderno e ao subsidiário. Contudo, o popular deve ser visto mais como algo construído que como préexistente.

Para o autor, na teatralização da cultura popular os três protagonistas são o folclore, as indústrias culturais e o populismo político. Para enfatizar sua crítica, Canclini sistematiza seis refutações à visão clássica dos folcloristas (p. 215-238):

a) o desenvolvimento moderno não suprime as culturas populares (estatísticas indicam aumento do percentual de artesãos na população econômica ativa de paises latino-americanos);

b) as culturas camponesas e tradicionais já não representam a parte majoritária da cultura popular (há participação significativa de populações urbanas e uma maior relação com a vida urbana);

c) o popular não se concentra nos objetos (há maior preocupação da antropologia e da sociologia com as condições econômicas de produção e consumo, os comportamentos e processos comunicacionais, interações e rituais);

d) o popular não é monopólio dos setores populares (uma mesma pessoa pode participar de diversos grupos folclóricos; os processos comunica- 
cionais e práticas sociais também sofrem a intervenção de órgãos governamentais e da iniciativa privada);

e) o popular não é vivido pelos sujeitos populares como complacência melancólica para com as contradições (há muitas práticas rituais que transgridem humoristicamente a simples reprodução da ordem tradicional, como os carnavais);

f) a preservação pura das tradições não é sempre o melhor recurso popular para se reproduzir e reelaborar sua situação (a incorporação de novas tecnologias e/ou materiais em adaptação ao mercado pode significar uma consolidação para comunidades tradicionais sem desvirtuá-las).

Para o autor, assim como a análise das artes cultas, o exame das culturas populares requer livrar-se da pretensão de autonomia absoluta, de uma pureza ou de uma auto-suficiência sem relação com as indústrias culturais, o turismo, as relações econômicas e políticas com o mercado nacional e transnacional de bens simbólicos.

No capítulo seis, Popular, popularidade: da representação política à teatral, Canclini faz a crítica à apropriação da cultura popular pela indústria cultural e pelas classes políticas.

De acordo com o autor, a "noção de popular construída pelos meios de comunicação, e em boa parte aceita pelos estudos nesse campo, segue a lógica do mercado. Popular é o que se venda maciçamente, o que agrada as multidões. A rigor, não interessa ao mercado e à mídia o popular e sim a popularidade” (p. 260). Nessa visão, o popular não interessa como tradição que perdura. Ao contrário, prevalece uma "lei da obsolescência incessante": tudo deve ser constantemente renovado. "O popular massivo é o que não permanece, não se acumula como experiência nem se enriquece com o adquirido” (p. 261).

No populismo, por sua vez, "os valores tradicionais do povo, assumidos e representados pelo Estado, ou por um líder carismático, legitimam a ordem que estes últimos administram e dão aos setores populares a confiança de que participam de um sistema que os inclui e os reconhece” (p. 264).

Para Canclini, o populismo tornou possível para os setores populares novas interações com a modernização, tanto com o Estado quanto com outros agentes hegemônicos, fazendo com que parte de suas demandas fossem parcialmente atendidas. No entanto, o autor destaca três mudanças ocorridas nos últimos anos que debilitam esse tipo de constituição popular: as transformações geradas pelas indústrias culturais, como o alto custo uma campanha eleitoral, ressignificando o campo político sob a ótica da lógica publicitária; a crise econômica e a reorganização neoliberal dos Estados, 
com a estagnação e a recessão dos anos 80, que implicam escassez de verbas para atender as reivindicações populares; o desinteresse do povo pela atuação político-partidária e a crescente atuação das informações jornalísticas (a mediação política entre movimentos populares e o aparelho governamental ou partidário é substituída por uma mediação simbólica da imprensa e dos programas de informação da mídia).

Canclini destaca que na busca pela investigação do popular sobressaem a teoria da reprodução e a concepção gramsciana da hegemonia. A primeira vê a cultura popular como resultado da apropriação desigual dos bens econômicos e simbólicos por parte dos setores subalternos. A segunda vê as culturas populares retomando suas tradições e experiências próprias no conflito com os que exercem a hegemonia.

No sétimo capítulo, Culturas híbridas, poderes oblíquos, Canclini expõe o que ele considera como exemplos de uma construção da hibridez cultural presente nas sociedades latino-americanas.

Para o autor, a expansão urbana é uma das causas que intensificaram a hibridação cultural. Cidade e meio rural se articulam pela mídia eletrônica. A mobilização social, do mesmo modo que a estrutura da cidade, fragmentase em processos cada vez mais difíceis de totalizar, e a eficácia dos movimentos sociais, por sua vez, cresce quando atuam nas redes massivas.

A vida urbana transgride a ordem "imposta" pelo desenvolvimento moderno na tentativa de distribuir os objetos e os signos em lugares específicos e classificar as "coisas" e as "linguagens" que falam delas, com uma organização sistemática dos "espaços" sociais em que devem ser consumidos. Como os monumentos, que abertos à dinâmica urbana, facilitam que a memória interaja com a mudança, que os heróis nacionais se revitalizem graças à propaganda ou ao trânsito.

A "agonia das coleções", por sua vez, "é o sintoma mais claro de como se desvanecem as classificações que distinguiam o culto do popular e ambos do massivo. As culturas já não se agrupam em grupos fixos e estáveis” (p. 304). Proliferam os dispositivos de reprodução que não podem ser definidos como cultos ou populares: fotocopiadoras, videocassetes, vídeo clips, videogames. Neles se perdem as coleções, desestruturam-se as imagens e os contextos, as referências semânticas e históricas que amarravam seus sentidos.

"As buscas mais radicais sobre o que significa estar entrando e saindo da modernidade são as dos que assumem as tensões entre desterritorialização” (p. 309). Na análise dessa transformação das culturas, Canclini enfoca a transnacionalização dos mercados simbólicos (como a massificação dos 
mercados culturais nacionais) e as migrações (os fenômenos de desterritorizalização e reterritorialização ligados aos migrantes), e o sentido estético dessa mudança seguindo as estratégias de algumas artes "impuras", como o grafite e as histórias em quadrinhos, consideradas pelo autor como "constitucionalmente híbridas”.

Canclini afirma que a hibridez tem um longo trajeto nas culturas latino-americanas. Os projetos de independência e desenvolvimento nacionais buscaram compatibilizar o modernismo cultural com a semimodernização econômica, e ambos com as tradições persistentes.

Outro modo pelo qual a obliqüidade dos circuitos simbólicos permite repensar os vínculos entre cultura e poder é a busca de mediações, de vias diagonais para gerir os conflitos, como a satirização da classe política, expressa nos Carnavais, nos grafites e/ou no humor jornalístico. Contudo, para Canclini, as práticas culturais são, mais que ações, atuações. “[...] Talvez o maior interesse para a política de levar em conta a problemática simbólica não resida na eficácia pontual de certos bens ou mensagens, mas no fato de que os aspectos teatrais e rituados do social tornem evidente o que há de oblíquo, simulado e distinto em qualquer interação” (p. 330).

Assim como declara já na parte inicial de sua obra, as considerações finais do autor, expressas na Saída, afirmam que a análise exposta no livro "não permite estabelecer relações mecânicas entre modernização econômica e cultural. Nem tampouco ler esse processo como simples atraso. [...] Essa modernização insatisfatória deve ser interpretada em interação com as tradições que persistem” (p. 353).

Para Canclini, a compreensão da modernidade requer observar, ao mesmo tempo, as formas de entrada e saída que nela ocorrem. Vê-la com uma condição que nos envolve. Compreender como se reestruturam os agentes sociais que participam tanto do campo culto ou popular quanto do massivo e como isso abranda as fronteiras entre seus praticantes e seus estilos.

Tais relações devem revelar, claramente, aquilo que autor denominou de culturas híbridas. 


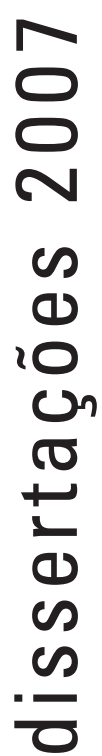

잉

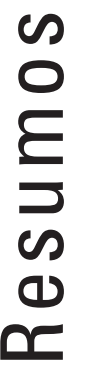





\title{
1. Formas de Apropriação Dos Espaços Externos E Privados No Setor Bela Vista Em Goiânia-GO: Estudo De Caso.
}

\author{
Autor: Lorena Rodrigues Leite Caixeta \\ Data da Defesa:07/03/2007 \\ Banca Examinadora: \\ Prof. Dr. João Batista de Deus \\ Prof. ${ }^{\text {a }}$ Dr. ${ }^{\text {a Beatriz Ribeiro Soares }}$ \\ Prof. Dr. Eguimar Felício Chaveiro
}

\section{RESUMO}

A busca pela facilidade de trabalho e meio de sobrevivência faz com que os indivíduos migrem das zonas rurais e pequenas cidades para grandes centros urbanos, provocando um crescimento acelerado e desordenado. Assim, os padrões habitacionais relacionam-se direta ou indiretamente, dentre outros aspectos, com o modo de apropriação do espaço intra-urbano e incorrem em problemas ambientais que afetam a qualidade de vida dos citadinos. Proliferam nas grandes cidades, os ambientes inóspitos, promovidos, dentre outros motivos, por políticas que conduzem à segregação sócioespacial que expõe a insuficiência de acesso à infra-estrutura. Uma delas encontra-se na oferta de espaços verdes. Em Goiânia, apesar dos estudos já existentes sobre áreas verdes serem poucos, observa-se também que os mesmos tratam basicamente das áreas públicas e da arborização urbana. Não contemplam, de maneira mais detalhada, as áreas externas das habitações de uso individual - áreas privadas externas - que não podem servir para usufruto direto da população geral, embora possam indiretamente contribuir para seu bem-estar. 0 estudo a seguir além de trazer um levantamento bibliográfico focando os vários aspectos que irá ser tratado neste estudo com relação ao setor Bela Vista, situado em Goiânia, trará um estudo quantitativo através de entrevistas com os próprios moradores da região, bem como suas análises.

Palavras Chaves: Zoneamento, estrutura, Bela Vista - Goiânia.

\section{As Transformações Da Paisagem: Contribuição Ao Estudo Da Formação De Areais Na Bacia Do Ribeirão Sujo, Município De Serranópolis/GO.}

\author{
Autor: Marluce Silva Sousa \\ Data da Defesa:30/03/2007 \\ Banca Examinadora: \\ Profa. Dra. Luciana Maria Lopes \\ Profa. Dra. Dirce Maria Antunes Suertegaray \\ Prof. Dr. Valter Casseti
}

\section{RESUMO}

0 Ribeirão Sujo é afluente da margem direita do Rio Verde que, por sua vez, é afluente do Rio Paranaíba. Sua microbacia abrange área de 165 km2 no município de Serranópolis, na microrregião Sudoeste de Goiás, apresentando extensas manchas de solos arenosos degradados e sem cobertura vegetal, chamados de "areais". Nesta microbacia foram 
analisados os condicionantes naturais e as transformações da paisagem pelos processos sociais para compreender a formação dos areais. A análise baseou-se na avaliação individual e, também, integrada dos elementos físicos da paisagem, a partir dos quais foram estabelecidas seis unidades de paisagem. Avaliaram-se as potencialidades e limitações das unidades de paisagem com base na aptidão agrícola das terras, na fragilidade potencial e na legislação ambiental. Verificou-se a transformação da paisagem por processos sócio-econômicos, identificando-se suas transformações históricas e comparando-se o uso da terra em diferentes períodos, bem como suas implicações nas unidades de paisagem. A paisagem da bacia do Ribeirão Sujo sofreu uma série de transformações impostas pelas atividades sociais que nela se implantaram. As mais significativas ocorreram a partir da década de 1980, com a introdução de atividades agrícolas modernizadas, principalmente da monocultura da cana-de-açúcar. Por fim, analisou-se a distribuição e características dos areais, identificando-se aspectos de sua origem e evolução, com ênfase na compreensão do nível de degradação do solo. 0 processo de formação de areais envolve uma dinâmica que se desencadeou a partir do manejo inadequado do solo numa área de forte fragilidade potencial, originando pequenas manchas de areia exposta, cujo histórico evolutivo compreende, em geral, as seguintes etapas: retirada da vegetação nativa de cerrado, cultivo da cana-de-açúcar, num primeiro momento, e após, semeadura de braquiária, cujo estabelecimento tornou-se precário em função da fertilidade e do manejo do solo, desencadeando processos erosivos e redução nos teores de nutrientes e de matéria orgânica. Por fim, a excessiva pressão de pastejo determinou o colapso total da fraca estrutura da camada superficial do solo e da própria pastagem, 0 que, por sua vez, facilitou a expansão dos areais. A dimensão dos areais já perfaz $1,4 \%$ da área da microbacia, sendo que o maior atinge cerca de 79 ha. Esses areais ocupam diversas posições topográficas, com maior incidência em rampas convexas, secundariamente, rampas côncavas e topos. Atualmente, verifica-se nos areais a ocorrência de erosão laminar e, secundariamente, de erosão linear e eólica; entretanto, não se verifica relação causal exclusiva entre erosão e formação de areais, nem a ocorrência do areal é determinada unicamente pela deposição de areia. Concluiu-se que um dos principais fatores desencadeadores da formação de areais é o uso/manejo do solo. Sugere-se, de imediato, a implantação de medidas mitigadoras para conter 0 avanço dos areais e, com tempo, a sua possível recuperação.

Palavras-chave: Cerrado; Fragilidade ambiental; Uso e manejo do solo; Areais.

\title{
3. Meio Físico E Uso Da Terra Na Bacia Do Córrego Da Lagoinha, Anápolis (G0)
}

\author{
Autor: Lidiane Ribeiro dos Santos \\ Data da Defesa:18/04/2007 \\ Banca Examinadora: \\ Profa. Dra. Luciana Maria Lopes \\ Profa. Dra. Suely Regina Del Grossi Michelotto \\ Prof. Dr. Alfredo Borges de Campos
}

\section{RESUMO}

Na bacia do córrego da Lagoinha, à noroeste da cidade de Anápolis, procedeu-se à análise ambiental através do exame integrado dos condicionantes do meio físico visando a identificação dos distintos setores do relevo e conhecimento das suas fragilidades e potencialidades. As indagações que nortearam a pesquisa foram: "Qual a natureza, atributos e propriedades dos componentes do meio físico da bacia? Quais os compartimentos morfopedológicos? Qual a importância do conhecimento do meio físico para a avaliação das potencialidades e fragilidades dos distintos setores da paisagem? 0 uso atual da terra está em consonância com seu potencial de uso? Há impactos decorrentes do uso? Quais são? A continuar o tipo de uso/ocupação atuais da terra na bacia, qual o prognóstico para a área?" Para tal foram, através do exame dos condicionantes geologia-relevo-solos-vegetação e uso/ocupação da terra, e da interação entre eles, delimitados quatro compartimentos morfopedológicos: Cimeira, das Morrarias, Inferior e Planícies Fluviais. 0 Compartimento de Cimeira, com altitudes entre 1140 a $1060 \mathrm{~m}$, e com declividades entre $0-12 \%$, é revestido por laterita ferruginosa com solos do tipo Plintossolos Pétricos Concrecionários, a vegetação natural sendo a de Cerrado sobre os solos dis- 
tróficos. Este compartimento possui fragilidade Muito Fraca a Fraca, com capacidade de uso no Grupo B - Classe Vs, com pouca a nenhuma suscetibilidade à erosão laminar e linear. 0 uso indicado é de preservação permanente nos 100 $\mathrm{m}$ à montante da escarpa que delimita o compartimento de Cimeira daquele das Morrarias, enquanto no restante 0 uso deve ser controlado por se tratar de área de recarga do lençol freático. 0 compartimento das Morrarias, com cotas entre 1060 a 940 m, com declividades entre $12-20 \%$ (predominantes), 20 a $30 \%$ (restritas) e 30 a $50 \%$ (pontuais) foi elaborado, assim como os demais, sobre as rochas do Complexo Granulítico Anápolis-Itauçú. Apresenta um alinhamento estrutural NW-SE de interflúvios estreitos de vertentes declivosas e vales profundos e encaixados. Os solos são os Cambissolos associados aos Argissolos Vermelho Amarelos e Neossolos Litólicos restritos. A vegetação natural é de remanescente de Floresta Estacional Decidual e Semidecidual sobre os solos, no geral, eutróficos. Este compartimento possui fragilidade Média a Muito Forte, com capacidade de uso no Grupo B - Vlles. Os solos, extremamente suscetíveis à erosão laminar, são suscetíveis à ravinas, e não suscetíveis a voçorocas, pois se tratam de solos rasos com ausência de lençol freático. 0 Compartimento Inferior, situado entre 940 a $850 \mathrm{~m}$ de altitude, e com declividades entre 3 e $12 \%$, apresenta interflúvios amplos com vertentes longas retilíneas a suavemente convexiformes revestidas por Latossolos Vermelhos, a vegetação natural sendo a de remanescentes da Floresta Estacional Decidual e Semidecidual. 0 compartimento Inferior possui fragilidade classificada como Fraca a Muito Fraca, e capacidade de uso das terras no Grupo A - Classe I. É considerado como pouco suscetível à erosão, porém se mal manejado ou submetido à fluxos de água concentrados torna-se muito suscetível à erosão. Este compartimento é o mais indicado à urbanização e a cultivos diversos, sem necessidade de técnicas complexas de conservação. Na Planície Fluvial, entre 940 a $850 \mathrm{~m}$ de altitude, e com declividades entre 0 e 6\%, os solos são os Gleissolos Melânicos e a vegetação natural mais comum é a de taboa. Possui fragilidade muito fraca, sendo entretanto extremamente suscetível à inundações, com capacidade de uso enquadrada no Grupo $\mathrm{C}$ - VIlla. Seus terrenos apresentam suscetibilidade erosiva nula mas não são indicados à urbanização ou qualquer tipo de edificações desde que instáveis.

Palavras-chave: Bacia hidrográfica, Compartimentos morfopedológicos, Fragilidade Ambiental, Capacidade de uso, Uso atual, Suscetibilidade à erosão, Diretrizes de uso.

\title{
4. Impactos Ambientais Na Alta Bacia Urbana Do Rio Das Antas Em Anápolis (GO).
}

\author{
Autor: Andrelisa Santos de Jesus \\ Data da Defesa:18/04/2007 \\ Banca Examinadora: \\ Profa. Dra. Luciana Maria Lopes \\ Profa. Dra. Suely Regina Del Grossi Michelotto \\ Profa. Dra. Maria Amélia Leite Soares do Nascimento
}

\section{RESUMO}

A alta bacia do rio das Antas possui aproximadamente $17 \mathrm{~km} 2$, situando-se numa área de expansão urbana na porção sudoeste de Anápolis. Elaborada sobre paragranulitos do Complexo Granulítico Anápolis-Itauçú, apresenta distintos modelados. 0 Modelado de Aplanamento, com altitudes acima de $1100 \mathrm{~m}$, com declividades predominantemente inferiores a $5 \%$, caracteriza-se pela presença de topos planos sustentados por laterita ferruginosa. 0 Modelado de Dissecação, com altitudes entre 1100 e $<1000 \mathrm{~m}$, abrange o domínio das vertentes compartimentadas em vertentes do trecho superior, com declividades de 5 a $10 \%$, vertentes médias com valores entre $10 \%$ e $>25 \%$, e baixas vertentes que voltam a exibir valores entre 5 e 10\%, todas recobertas por Latossolos Vermelho-Amarelos. 0 Modelado de Acumulação, com altitudes $<1000 \mathrm{~m}$, possui declividades inferiores a $5 \%$ compreendendo uma planície de inundação segmentada evidenciada pela característica plana e pela presença de aluvião e de Gleissolos. Tal bacia é área de tensão ecológica 
com vegetação de Cerrado no Modelado de Aplanamento e de remanescentes da Floresta Estacional nas vertentes dos interflúvios, destacando-se ocorrências pontuais de Mata de Galeria inundável em áreas de proximidade do lençol freático. As primeiras formas de uso e ocupação da terra na bacia ocorreram pela agropecuária que se encarregou de desmatar parte considerável da vegetação natural. Posteriormente, o uso do solo foi se tornando urbano e, gradativamente, a área foi sendo parcelada. Tal parcelamento não ocorreu necessariamente em função de uma demanda social, mas para atender interesses associados a uma explícita especulação imobiliária o que contribuiu para a implantação de loteamentos sem infraestrutura adequada que considerasse as fragilidades naturais do meio físico e, principalmente, a importância de uma vida digna para os moradores. Da implantação dos bairros sem infra-estrutura sobre vertentes longas revestidas por solos suscetíveis à erosão resulta que a área da bacia é intensivamente afetada por erosões em sulcos, ravinas e voçorocas tendo sido cadastras 14 voçorocas, 28 ravinas, 52 áreas afetadas por sulcos, e 20 áreas afetadas por uma associação de sulcos e ravinas. A grande maioria dos focos erosivos ocorrem no Modelado de Dissecação especialmente nas vertentes com declividades entre 10 e $25 \%$ na margem leste da bacia onde o comprimento da vertente é maior. Os horizontes A + B do Latossolo Vermelho Amarelo que revestem as vertentes são pouco espessos, de modo que as incisões erosivas atingem rapidamente o horizonte $C$ muito profundo e altamente friável derivado da alteração de rocha félsica rica em quartzo (paragranulito). A suscetibilidade erosiva de tais solos é potencializada pela implantação de ruas no sentido da declividade, a maioria desprovida de pavimentação asfáltica e de microdrenagem. Outro fator que contribui para a instalação de erosões é a ocorrência de chuvas de verão de alta intensidade e curta duração que concorrem à formação de fluxos concentrados de água. Às incisões erosivas associam-se depósitos tecnogênicos exemplificados por aterros resultantes do lançamento de entulho e lixo. Esse lixo é carreado, junto com as partículas do solo, para o leito do rio das Antas onde existem cones de dejeção bem esboçados que evidenciam o assoreamento do rio das Antas, processo também muito nítido à jusante no lago do Parque Onofre Quinan. 0 assoreamento do Antas, juntamente com outros fatores, favorece a ocorrência de inundações, tendo sido também registrados vários pontos de alagamento associados à impermeabilização do solo e ineficiência da microdrenagem. Todos esses impactos agravam a já precária qualidade de vida dos moradores da bacia dificultando, entre outros procedimentos comuns, sua trafegabilidade, e os colocando à mercê de vários riscos tais como quedas e contaminação.

PALAVRAS-CHAVE: Bacia hidrográfica, meio físico, uso da terra, erosão, qualidade de vida.

\title{
5. Chuva, Erodibilidade, Uso Das Terras E Erosão Hídrica Na Alta Bacia Do Rio Araguaia.
}

\author{
Autor: Neiva Maria Pio de Santana \\ Data da Defesa:04/05/2007 \\ Banca Examinadora: \\ Profa. Dra. Selma Simões de Castro \\ Prof. Dr. Iraci Scopel \\ Prof. Dr. Marcos Noberto Boin
}

\section{RESUMO}

0 intenso processo de ocupação do Centro-0este brasileiro nas últimas décadas vem impactando, significativamente, os recursos naturais, sendo a erosão hídrica uma das conseqüências mais graves. A alta bacia do Rio Araguaia é representativa desse processo, devido a uma convergência de fatores, tais como: a existência de solos arenosos altamente suscetíveis, usos e manejos inadequados, elevado índice pluviométrico anual, concentrado em alguns meses e alta erosividade. Essa pesquisa objetiva identificar e caracterizar as ralações possíveis entre a dinâmica pluvial e espacialização da erosividade, erodibilidade, uso dos solos e os focos erosivos lineares (ravinas e voçorocas) visando 
fornecer subsídios para a avaliação da suscetibilidade e risco à erosão para fins de planejamento ambiental. A abordagem adotada neste estudo apoiou-se no princípio da análise sistêmica ou integrada de cunho geoambiental, baseada na correlação e integração de dados, na climatologia dinâmica e geográfica, que prevê os movimentos combinados dos elementos e fatores do clima, com ênfase nas chuvas, considerando-se sua influência nas paisagens e vice-versa e no contexto de bacia hidrográfica como categoria de análise espacial de referência. Os resultados revelaram: concentração de chuvas no tempo (primavera-verão) e no espaço (setores das nascentes dos tributários do rio Araguaia, além dele próprio); concentração dos focos erosivos a leste, numa faixa central e sul, onde se encontram também os maiores índices de erosividade e erodibilidade (solos suscetíveis) e maiores áreas de conversão do Cerrado nativo em agricultura e pastagem, não raro, degradada. Revelaram paralelamente que áreas preservadas (a oeste), apesar da erosividade e erodibilidade elevadas não apresentaram fenômeno erosivo e finalmente que os índices pluviométricos anuais podem estar diminuindo desde 1970.

PALAVRAS-CHAVE: Precipitação pluvial; erodibilidade; uso e ocupação do solo; erosão linear.

\title{
6. Entre A Conquista E A Permanência Na Terra: Formas De Luta No Assentamento Mosquito No Município De Goiás-G0, 1986/2006.
}

\author{
Autor: José Braga Coelho \\ Data da Defesa:10/05/2007 \\ Banca Examinadora: \\ Profa. Dra. Celene Cunha Monteiro Antunes Barreira \\ Profa. Dra. Vera Lúcia Salazar Pessôa \\ Prof. Dr. Barsanufo Gomides Borges
}

\section{RESUMO}

Apresenta-se nesse trabalho a luta pela conquista da terra, que organizada de forma coletiva teve como primeiro resultado no município de Goiás o Assentamento Mosquito, sendo esse o primeiro no município e um dos primeiros no Estado de Goiás. A origem da apropriação da terra no Brasil se deu com a formação de grandes propriedades, as quais prevalecem até os dias atuais. No país foram freqüentes as políticas públicas incentivando o movimento de fronteira demográfica e econômica na ocupação do interior, beneficiando a grande produção e a formação de grandes propriedades, registrando também constantes conflitos entre a frente de expansão e a frente capitalista. 0 mais recente desses movimentos foi a modernização da agricultura brasileira, que exigindo a presença de maior volume de capital, direcionou a agricultura para as áreas de cerrado, condenando ao esfacelamento a pequena propriedade e 0 trabalhador do campo que vivia em função da oferta de sua força de trabalho. Assim, além da concentração de terras intensificou a migração rural urbana, o crescimento desordenado dos grandes centros urbanos, o favelamento, o desemprego e a fome. Tudo isso fez com que a classe de trabalhadores sem terra no campo e sem emprego na cidade, se organizasse coletivamente iniciando um processo de ocupação de latifúndios improdutivos, de terras devolutas ou de documentação ilegal. No município de Goiás, esse processo iniciou antes da criação do Movimento de Trabalhadores Rurais Sem Terra (MST), quando no ano de 1985 aconteceu a ocupação da fazenda São Sebastião do Mosquito, que resultou na desapropriação da área e criação de um dos primeiros assentamentos de reforma agrária do Estado de Goiás, quando 42 famílias foram assentadas no dia 08 de agosto de 1986. A baixa fertilidade do solo fez com que muitas parcelas fossem comercializadas, porém, atualmente as famílias do assentamento lutam de diversas formas no sentido de vencer os obstáculos que dificultam a sua permanência na terra. Assim o objetivo dessa pesquisa é analisar a estrutura e organização do Assentamento Mosquito através do olhar geográfico.

PALAVRAS-CHAVE: Fronteira - Latifúndio - Assentamento Rural - Reforma Agrária. 


\title{
7. Rali De Jegues De Turvânia-G0: A Refuncionalização Da Paisagem Para 0 Lazer E Turismo No Mato-Grosso Goiano.
}

\author{
Autor: Romero Ribeiro Barbosa \\ Data da Defesa:03/05/2007 \\ Banca Examinadora: \\ Profa. Dra. Maria Geralda de Almeida \\ Prof. Dr. Jadir de Morais Pessoa \\ Prof. Dr. Marcelo Rodrigues Mendonça
}

\section{RESUMO}

Esta dissertação propõe investigar a modalidade esportiva denominada de rali de jegues que ocorre durante três dias do ano, na cidade de Turvânia. Esta cidade situa-se a $90 \mathrm{~km}$ da capital goiana, na região central do Estado conhecida como 0 antigo Mato-grosso goiano. 0 objetivo é analisar a relação entre a paisagem local, de tradição agropecuária com a prática do lazer e do turismo, por meio do rali de jegues. Essa cidade, como a maioria dos municípios goianos, surgiu a partir do desenvolvimento da agricultura e da pecuária - tradição que o Estado de Goiás herdou após o período aurífero e que ainda constitui-se como a base de sustentação da economia local. No mês do aniversário de emancipação do município (14/11/1962), teve início uma nova prática esportiva que, a cada adquire dimensões sociais relacionadas ao crescimento de turistas em direção ao município. Entre os anos 2002 e 2006, ocorreu um aumento bastante significativo em relação ao número de expectadores (turistas) e competidores. Estes últimos eram $13 \mathrm{em} 2002$ e $38 \mathrm{em} 2006.0$ número de expectadores obteve expressivo crescimento: 500 em 2002 e 10.000 em 2006. Essa mobilidade de turistas e competidores em função do rali de jegues desencadeia múltiplos olhares da mídia regional como também de outros Estados. A paisagem agrícola e pecuária local, tradição do município, se apresenta com uma nova função, mesmo que sazonalmente, ao permitir a realização de uma modalidade esportiva voltada ao entretenimento. Se, conforme Cosgrove (1998, p.108) "todas as paisagens possuem significados simbólicos porque são produtos da apropriação e transformação do meio ambiente pelo homem". Para esta dissertação adota-se o conceito de paisagem alternativa.

PALAVRAS-CHAVE: Rali, jegues, refuncionalização da paisagem, lazer, turismo.

\section{0 Jovem E A Cidade: Um Estudo Sobre Os Jovens Migrantes E Sua Relação Com Goiânia.}

\author{
Autor: Eliete Moreira dos Santos \\ Data da Defesa:22/05/2007 \\ Banca Examinadora: \\ Profa. Dra. Lana de Souza Cavalcanti \\ Profa. Dra. Maria Tereza Canezin Guimarães \\ Prof. Dr. Eguimar Felício Chaveiro
}

\section{RESUMO}

Goiânia representa, atualmente, a cidade da região metropolitana que concentra a maior quantidade de instituições de ensino superior do Estado de Goiás, proporcionando um fluxo de vários estudantes de todo o Estado, principalmente 
da região metropolitana, para estudarem na capital. A migração de jovens para Goiânia com o objetivo de estudo é um ponto relevante no contexto da UFG, uma vez que mais de $30 \%$ dos estudantes precisam se deslocar de seu local de residência para estudarem na universidade. Neste sentido, é preciso conhecer os espaços que a cidade proporciona para tais práticas; e conhecer esses espaços requer interesses e vivências que promovam seu acesso até que este se torne 0 seu lugar. A cidade engloba diferentes formas de apropriação e prática, que são determinadas conforme 0 objetivo de cada agente modelador e construtor deste espaço. Também são de diferentes perspectivas os olhares sobre a cidade, por isso a importância de uma análise da imagem da cidade para o migrante, pois a partir disso pode-se chegar ao conteúdo da prática espacial produzida. Assim, o objetivo dessa dissertação é entender o migrante jovem enquanto segmento social que se integra à produção da cidade, apreende sua imagem e a partir dela realiza sua prática espacial. 0 trabalho teve uma abordagem metodológica dentro da perspectiva da pesquisa qualitativa pelo viés do estudo de caso. Os sujeitos da pesquisa foram os alunos migrantes universitários da UFG, que passaram a morar em Goiânia em função de estudos. Os resultados demonstraram que as principais referências espaciais da cidade de Goiânia para o jovem são os espaços destinados ao lazer, sendo que grande parte desses espaços está localizada nos bairros nobres ou centrais da cidade. A imagem que os jovens migrantes têm da cidade contém mais aspectos positivos do que negativos. A prática espacial dos jovens migrantes passa por uma imagem que se constrói a partir de percepções pré-estabelecidas da cidade que se realimentam na experiência cotidiana com o espaço de destino. Neste sentido, conclui-se que as práticas espaciais dos migrantes jovens não se distinguem da população jovem em geral, entretanto, suas percepções espaciais de Goiânia contêm perspectivas diferentes que carregam boas expectativas frente ao seu futuro e ao da cidade.

PALAVRAS-CHAVE: Migrante, Jovem, Imagem, Prática espacial, Cidade, Cotidiano.

\title{
9. Corpos Negros Femininos Em Movimento: Trajetórias Socioespaciais De Professoras Negras Em Escolas Públicas.
}

\author{
Autor: Lorena Francisco de Souza \\ Data da Defesa:29/06/2007 \\ Banca Examinadora: \\ Prof. Dr. Alecsandro José Prudêncio Ratts \\ Profa. Dra. Denise Maria Botelho \\ Profa. Dra. Lana de Souza Cavalcanti
}

\section{RESUMO}

Esta pesquisa trata-se de um estudo que envolve uma análise sobre gênero, raça e espaço na Geografia. Existem diferenças culturais entre o masculino e o feminino na maneira de conceber o mundo e vivê-lo e nas desigualdades postas por uma sociedade herdeira do poder masculino e, principalmente, branco. A pesquisa focaliza uma proposta de análise e reflexão sobre gênero, raça - enquanto uma construção social - e as trajetórias socioespaciais de um grupo socialmente discriminado, e, não raro, segregado, representado por mulheres negras no ofício de professoras. 0 objetivo maior é, assim, compreender as trajetórias socioespaciais (escola, casa e outros "espaços") vividas e construídas pelas professoras negras em Goiânia ao longo de sua existência, deparando-se com manifestações explícitas e implícitas de preconceito, discriminação, desvantagem no mercado de trabalho e refletir sobre os espaços ocupados por tais muIheres enquanto professoras, mães e cidadãs. A metodologia utilizada para a realização da pesquisa consistiu em uma revisão bibliográfica sobre a temática relacionada ao objeto de estudo, roteiro de entrevistas que exploraram a história de vida das professoras, possibilitando uma análise dos espaços de confronto, sociabilidade e estranhamento de tais atrizes sociais perante a coletividade e 0 imaginário social. Após a coleta de dados e realização das entrevistas, foram elaboradas mapas temáticos relacionados aos deslocamentos espaciais realizados pelas professoras. A presença de professoras negras nas escolas públicas citadas desperta a necessidade de uma organização que ressalte uma preocu- 
pação coletiva com a questão racial. As diferenças sociais são, não raramente, fruto de imaginários construídos, firmados por mitos que insistem em permanecer na estrutura de uma determinada sociedade, como o da democracia racial. Assim discutir os espaços sociais e os lugares vividos por professoras negras permitiram compreender o propósito de reflexão ou mudança deste grupo estigmatizado pela cor, pelo gênero e pela classe social a que pertence.

PALAVRAS-CHAVE: raça, gênero, trajetórias socioespaciais.

\title{
10. A Evolução E Produção Da Estrutura Urbana Em Anápolis - 1993 A 2004: Estudo Da Interferência Das Gestões Municipais.
}

\author{
Autor: Regina Maria de Faria Amaral Brito \\ Data da Defesa:29/06/2007 \\ Banca Examinadora: \\ Prof. Dr. João Batista de Deus \\ Prof. Dr. William Rodrigues Ferreira \\ Profa. Dra. Celene Cunha Monteiro Antunes Barreira
}

\section{RESUMO}

A cidade de Anápolis encontra-se inserida na mesorregião Centro Goiano e as primeiras penetrações no território aconteceram em meados do século XIX, onde se fundou Anápolis por "tropeiros" que viajavam das regiões norte para o sul. A cidade situa-se no entroncamento das rotas entre importantes cidades que nasceram com a mineração entre os séculos XVII e XVIII e começou a cumprir a função de entreposto comercial para abastecimento dessas cidades bem como de outras localizadas entre o noroeste e nordeste do Estado. A sua evolução urbana foi sempre marcada pela pressão de parcelamentos "espraiados" de forma desordenada ao longo de seus $918,4 \mathrm{Km} 2$. Por iniciativa pública e/ou privada, a configuração do espaço urbano é o resultado das ações sociais, com forte atuação do Governo Municipal. Neste sentido entende-se que o papel do poder público ao longo destes anos foi decisivo para a evolução do espaço urbano do município. 0 presente projeto de pesquisa acadêmica pretende detectar no município de Anápolis, no período compreendido entre 1993 e 2004, os efeitos das políticas urbanas aprovadas nas gestões municipais e as conseqüências destas decisões na produção de sua estrutura urbana. Para tanto serão analisados aspectos econômicos, sociais e políticos que espacializados contribuíram para um estudo exploratório da interferência das decisões do poder publico na evolução da configuração urbana. Esta problematização passa pela articulação de três momentos fundamentais: inicialmente delineando considerações sobre a cidade enquanto centralidade na região e os aspectos que auxiliam a leitura do município; em um segundo momento contextualizando a questão da Gestão urbana; e finalmente apresentamse as administrações públicas municipais no período de 1993 a 2004 confrontando os objetivos do Plano Diretor às leis de Política Urbana do período, dando ênfase à discussão dos aspectos relativos à ampliação do perímetro urbano, reincidente em diversas administrações.

PALAVRAS-CHAVE: Espaço urbano. Gestão municipal. Política urbana. Processo de produção do espaço urbano 


\title{
11. Conhecimentos Acadêmicos E Conhecimentos Práticos: A Formação Do Professor De Geografia Nos Primeiros Anos De Experiência Profissional.
}

\author{
Autor: Regiane Alves da Fonseca \\ Data da Defesa:06/06/2007 \\ Banca Examinadora: \\ Profa. Dra. Lana de Souza Cavalcanti \\ Profa. Dra. Beatriz Aparecida Zanatta \\ Prof. Dr. Eguimar Felício Chaveiro
}

\section{RESUMO}

Este estudo teve como foco principal abordar a distância que existe entre os conhecimentos acadêmicos geográficos e os conhecimentos efetivamente práticos de um docente de Geografia em inicio de experiência profissional e investigar como 0 processo de construção da identidade profissional ocorre através da mediação: formação acadêmica e pratica pedagógica. A pesquisa se constitui numa perspectiva metodológica qualitativa de cunho etnográfico. Na etapa de levantamento de dados serão observados, entrevistados e acompanhados seis docentes da área de Geografia, do ensino fundamental, de três instituições de ensino: estadual, municipal e privada, da cidade de Goiânia, no estado de Goiás, que tenham se formados nestes últimos cinco anos.

PALAVRAS-CHAVE: Prática docente, Formação de professores, Identidade profissional, Ensino fundamental e Geografia.

\section{0 Agronegócio E As Potencialidades Turísticas Do Município De Rio Verde-Goiás.}

\author{
Autor: Roberto Eduardo Castillo Pizarro \\ Data da Defesa:11/09/2007 \\ Banca Examinadora: \\ Profa. Dra. Maria Geralda de Almeida \\ Prof. ${ }^{a}$ Dr. ${ }^{\text {a }}$ Eliane Lopes Brenner \\ Prof. Dr. João Batista de Deus
}

\section{RESUMO}

Esta dissertação tem o objetivo discutir se 0 agronegócio possibilita ou não a criação /incentivos para 0 turismo no município de Rio Verde. 0 agronegócio foi resultado das políticas públicas que inseriram a modernização da agricultura e os pacotes tecnológicos e posteriormente possibilitaram o processo de agroindustrialização, constituindo por atualmente uma complexa cadeia produtiva denominada de agronegócio. Os eventos como a Exposição Agropecuária e a Agrishow-COMIGO são exemplos de formas de divulgação e comercialização dos produtos agropecuários e agroindustriais. Alem destes eventos, o aumento das taxas de ocupação da rede hoteleira nos últimos anos, levantou a idéia do desenvolvimento do turismo na cidade. Porém, o desconhecimento das potencialidades turísticas por parte dos empresários dos meios de hospedagem, A\&B (alimentos e bebidas) da população local e ainda, da inexperiência dos agentes públicos ligados ao turismo, desarticulam até o momento o turismo como nova atividade econômica do muni- 
cípio. Existem além dos eventos ligados ao agronegócio, as potencialidades turísticas culturais e naturais que podem ser exploradas pelo turismo e seus agentes promotores.

PALAVRAS-CHAVE: agronegócio, turismo, turismo de negócio e eventos, potencialidade turísticas, Rio Verde - Goiás

\title{
13. Trindade E 0 Abraço Ingrato Da Metrópole: Uma Análise Sócio-Territorial De Trindade II.
}

\author{
Autor: Wildes Jesus Rodrigues \\ Data da Defesa:14/09/2007 \\ Banca Examinadora: \\ Profa. Dra. Celene Cunha Monteiro Antunes Barreira \\ Prof. Dr. José Borzacchiello Silva \\ Profa. Dra. Elane Ribeiro Peixoto
}

\section{RESUMO}

Esse trabalho, intitulado "Trindade e o "abraço ingrato da metrópole": uma análise sócio-territorial de Trindade II, consiste na análise das transformações sócio-territoriais ocorridas, de modo geral, na cidade de Trindade e mais especificamente em uma área denominada Trindade II. Essas transformações se acirraram a partir da década de 1980, fruto de políticas urbanas adotadas pelo município de Goiânia e pelo processo de metropolização, em andamento. Os revérberos das políticas goianiense, unida aos processos transformantes da atual etapa do modo de produção capitalista, fragmentaram o território de Trindade, criando novas territorialidades e exigindo posturas diferentes para se administrar esse município. Buscamos interpretar os problemas sócio-territoriais em Trindade - G0, gerados pela fragmentação territorial ai decorrida. As conseqüências para Trindade, de ter um território dividido, são de base institucional e social. A primeira é marcada pela dificuldade da prefeitura de Trindade em estabelecer a gestão num território tão vasto e distante dos seus alicerces. Quanto a segunda, paira por sobre o município os ciúmes e as disputas entres as duas malhas urbanas para angariar mais benefícios. Neste último ponto, a cidade não é vista como um todo pelos moradores, mas em seu fragmento. Em outras palavras: o que é bom para uma das partes não é tido como bom para a cidade, mas para a porção beneficiada.

PALAVRAS-CHAVE: fragmentação territorial, metrópole, contradições sócio-espaciais.

\section{Geografia Política E Geopolítica: A Visão Dos Alunos Da Cidade De Goiás Construída A Partir Do Livro Didático De Geografia.}

\author{
Autor: Jean Molinari \\ Data da Defesa:14/09/2007 \\ Banca Examinadora: \\ Prof. Dr. Antonio Carlos Pinheiro \\ Prof. Dr. Sérgio Luiz Miranda \\ Prof. Dr. Eguimar Felício Chaveiro
}




\title{
RESUMO
}

0 presente trabalho tem a finalidade de questionar a visão de mundo que os alunos estão construindo, a partir do livro didático de geografia, principalmente, pela via da geografia política. Nesta pesquisa, a metodologia baseou-se na pesquisa social e na pesquisa teórica, a fim de combinarmos a teoria e os resultados coletados. A partir das informações coletadas e processadas, percebemos que o livro didático de geografia não privilegia a realidade local dos alunos. Esse fato nos leva a refletir que o desenvolvimento da aprendizagem deve considerar 0 apoio de instrumentos teóricos e didáticos que se aproximam da realidade local. Foi possível perceber que a visão que os alunos têm da geografia e o que ela pode nos proporcionar é, ainda, bastante limitada e fragmentada. 0 desenvolvimento e a ampliação de um olhar político-geográfico, que ultrapassem os conteúdos formais, permitem aos educandos compreenderem o sentido do conhecimento geográfico e os preparam para agir na sociedade como cidadãos críticos e reflexivos.

PALAVRAS-CHAVE: Geografia Política / Geopolítica - livro didático - conhecimento geográfico.

\section{Migração Internacional Dos Goianos: A Desterritorialização Globalizada Do Trabalho.}

\author{
Autor: Uelinton Barbosa Rodrigues \\ Data da Defesa:28/09/2007 \\ Banca Examinadora: \\ Prof. Dr. Eguimar Felício Chaveiro \\ Prof. Dr. Nildo Silva Viana \\ Prof. Dr. Manoel Calaça
}

\section{RESUMO}

A migração de goianos para os países desenvolvidos, especialmente para os Estados Unidos e países Europeus, é o objeto central do trabalho. Buscou-se compreender, a partir da categoria trabalho e das redes sociais de migrantes, as nuanças envolvidas na trama migratória. A ponte entre trabalho e redes sociais de migrantes permeia a análise que, embora considerando o fenômeno numa perspectiva totalizante, considerou as particularidades espaciais do goiano. A interpretação do processo migratório, a partir da captura do território goiano e das representações narradas pelo próprio migrante, são elementos fundamentais do trabalho, bem como as conseqüentes contradições que derivam do ato de migrar. 0 trabalho operou com dados, documentos, fotografias e também com fontes qualitativas que permitiram sintetizar que a migração do goiano para os países desenvolvidos revela Goiás, o mundo e os dramas sociais advindos de uma sociedade capitalista exploradora.

PALAVRAS-CHAVE: migração internacional; desterritorialização do trabalho; contradições sociais.

\section{6. Área De Influência Do Município De Pires Do Rio: A Região Trilho Das Penas.}

Autor: Michel Rezende Da Silveira

Data da Defesa:02/10/2007

Banca Examinadora: 


\author{
Profa. Dra. Celene Cunha Monteiro Antunes Barreira \\ Profa. Dra. Beatriz Ribeiro Soares \\ Prof. Dr. Marcelo Rodrigues Mendonça
}

\title{
RESUMO
}

Essa dissertação possui como objeto de estudo o município de Pires do Rio, que foi criado em 1922 em função da implantação da estrada de ferro, localizado na parte sudeste do Estado de Goiás. 0 objetivo é traçar um perfil regional da área de influência do município de Pires do Rio, que foi intitulada de Região "Trilho das Penas". Dessa forma, o primeiro capítulo aborda a categoria região como suporte de nossa análise. A partir daí, enfocou-se a discussão da dicotomia cidade-campo para posicionar que a observação da área de influência será feita a partir do município e não da cidade de Pires do Rio. Feito isso, delineamos as principais características dos municípios da microrregião de Pires do Rio e de dois municípios da microrregião de Catalão: Ipameri e Catalão. A partir desses municípios é que buscamos identificar a área de influência. No segundo capítulo, foi feita uma reconstrução histórica do município de Pires do Rio e seu retrato. A palavra retrato, nesse contexto, possui duplo sentido: 0 de retratar a realidade atual e 0 de mostrar - através de mapas, fotos e imagens - como em uma fotografia, o município. A intenção é fazer o leitor adentrar 0 ambiente em que a pesquisa transcorre. Desse modo, a dualidade sertão e modernidade goiana emergem para mostrar o processo histórico de construção de nosso Estado. Depois, foi demonstrada a atual configuração do município de Pires do Rio e, no final, trilhamos os caminhos de sua história. No terceiro capítulo, fizemos o dimensionamento da área de influência do Município de Pires do Rio. Para dimensionar a área de influência discutimos, primeiramente, as principais teorias regionais que nos serviram como base de análise dos dados. Após isso, fizemos uma análise dos principais estudos de planejamento que foram realizados no Brasil para, a partir dessas experiências, construirmos a metodologia que foi utilizada para aferir a área de influência. Assim, através dos dados de transporte, que foram nossa base, e os de educação e saúde, constatamos que o município de Pires do Rio influencia os municípios de Orizona, Palmelo, Santa Cruz de Goiás e Urutaí. No final, traçamos o perfil regional da área de influência do município de Pires do Rio: Região "Trilho das Penas".

PALAVRAS-CHAVE: Município de Pires do Rio, Perfil Regional, Região "Trilho das Penas".

\section{Trajetórias Do Sonho À Real Conquista: Formação Sócio Espacial E Luta Pela Moradia Em Goiânia.}

\author{
Autor: : Diana Dias Sampaio \\ Data da Defesa:17/10/2007 \\ Banca Examinadora: \\ Prof. Dr. João Batista de Deus \\ Prof. Dr. Francisco Capuano Scarlato \\ Prof. Dr. Eguimar Felício Chaveiro
}

\section{RESUMO}

A ocupação do Parque Oeste Industrial em fevereiro de 2004, em Goiânia, revelou um problema social que ocorre na maioria das metrópoles brasileiras. Em busca do sonho da casa própria organizou-se espontaneamente uma luta pelo direito à moradia considerado 0 direito à própria cidade e ao espaço urbano. 0 objetivo desse estudo foi investigar os interesses que permitiram a ocorrência desse conflito, que redundou na maior operação de despejo urbano de Goiás e que muito nos diz a respeito da luta pela moradia em Goiânia. Neste trabalho buscou-se, também, identificar as corre- 
lações de forças e agentes envolvidos nos processos de ocupação, edificação do "Sonho Real" e desocupação da área do Parque Oeste Industrial. E a partir das perspectivas geográfica e sócio-econômica, além das percepções de ordem política e sócio-cultural, visou-se chegar, mediante análise desse evento, a uma maior compreensão dos mecanismos de formação do espaço urbano que, por meio da especulação e monopólio da terra urbana, promovem a segregação sócio-ocupacional nas grandes cidades como Goiânia.

PALAVRAS-CHAVE: Luta por moradia, ocupação, especulação, fragmentação do solo urbano, segregação sócio-ocupacional. 



\section{NORMAS PARA PUBLICAÇÃO}

O Boletim Goiano de Geografia é uma publicação semestral, de circulação nacional, do Instituto de Estudos Sócio-Ambientais e do Programa de Pesquisa e pós-graduação em Geografia. A revista abre espaço para publicação de trabalhos inéditos sobre geografia e áreas afins, em diferentes enfoques teóricos e metodológicos. Os autores deverão enviar ao Conselho Editorial os trabalhos (artigos, notas, resenhas etc.) em disquete, acompanhado de duas cópias impressas. Recomenda-se o uso dos programas editores Word Perfect ou Word, na versão Windows. A extensão do texto poderá variar de 12 a 15 páginas, expaço duplo, para artigos e até 10 páginas para notas e resenhas.

O trabalho deverá ser estruturado, rigorosamente, da seguinte maneira:

Redigidos em português ou espanhol.

O cabeçalho deve conter o título em português e em espanhol ou inglês ou francês. Também deve ser informado a instituição a que pertence o autor, sua formação acadêmica, bem como o endereço postal e o e-mail.

Resumo, com o máximo de 200 palavras, acrescido de versão para o inglês ou espanhol ou francês, seguido das palavras chaves e key-words, palabras-clave ou mots clés.

A estrutura do texto deve ser dividida em partes não numeradas, sendo obrigatório a introdução e as considerações finais.

Texto (fonte Times New Roman), tamanho 12, com espaços duplo entre linhas.

Margens inferiores e superiores de $2 \mathrm{~cm}$ e 2,5cm, respectivamente.

Quanto a referencia aos autores no texto, será utilizado o último sobrenome do autor, conforme o exemplo: Santos (2000), Santos (2000, p. 22), (SANTOS, 2000).

Referências - dispostas em ordem alfabética pelo sobrenome do primeiro autor.

As figuras (desenhos, gráficos, mapas, esquemas, fotografias e cromos) e suas legendas deverão seguir em tons de cinza ou preto e branco, de modo a permitir uma perfeita legibilidade, em dimensões nunca superiores a $12 \mathrm{~cm} \times 16 \mathrm{~cm}$. 
Só serão aceitos textos revisados quanto às normas técnicas e à linguagem. Os autores receberão dois exemplares da revista que contiver seu artigo. Os direitos autorais serão cedidos para o Boletim Goiano de Geografia. Os trabalhos não selecionados não serão devolvidos aos autores. Será mantido em sigilo o nome dos pareceristas.

Os dados e conceitos emitidos nos trabalhos são de inteira responsabilidade dos autores.

\author{
Universidade Federal de Goiás - UFG \\ Instituto de Estudos Sócio-Ambientais - IESA \\ Campus II, Conjunto Itatiaia, Caixa Postal 131 \\ Fone: (62) 3521-1170 \\ $\triangle$ boletimgoianogeo@yahoo.com.br \\ www.revistas.ufg.br/index.php/bgg
}

Solicita-se permuta / Se solicita intercambio / We ask for exchange 


\begin{tabular}{r|l}
$\begin{array}{r}\text { Título } \\
\text { Preparação de originais } \\
\text { e revisão de textos }\end{array}$ & Boletim Goiano de Geografia \\
Normalização & Gráfica e Editora Vieira \\
Arte final de capa & André Barcellos \\
Editoração eletrônica & Diogo Nepomuceno Mendes \\
Formato fechado & $15,5 \times 21,5 \mathrm{~cm}$ \\
Mancha gráfica & $12,0 \times 17,5 \mathrm{~cm}$ \\
Tipologia & ZapfEllipt BT; Zurich Cn BT \\
Papel & Pólen Soft $80 \mathrm{~g} / \mathrm{m}^{2}(\mathrm{miolo})$ \\
& Cartão Supremo $250 \mathrm{~g} / \mathrm{m}^{2}$ (capa) \\
Número de páginas & 202 \\
Tiragem & 300 unidades \\
Impressão & Gráfica e Editora Vieira \\
&
\end{tabular}

